\title{
A meliorated Harris Hawks optimizer for combinatorial unit commitment problem with photovoltaic applications
}

\author{
Ayani Nandi ${ }^{1}$ and Vikram Kumar Kamboj ${ }^{2,3^{*}}$
}

\author{
${ }^{*}$ Correspondence: \\ dr.vikram.research@gmail. \\ com \\ ${ }^{2}$ School of Electronics \\ and Electrical Engineering, \\ Lovely Professional University, \\ Phagwara, India \\ Full list of author information \\ is available at the end of the \\ article
}

\begin{abstract}
Conventional unit commitment problem (UCP) consists of thermal generating units and its participation schedule, which is a stimulating and significant responsibility of assigning produced electricity among the committed generating units matter to frequent limitations over a scheduled period view to achieve the least price of power generation. However, modern power system consists of various integrated power generating units including nuclear, thermal, hydro, solar and wind. The scheduling of these generating units in optimal condition is a tedious task and involves lot of uncertainty constraints due to time carrying weather conditions. This difficulties come to be too difficult by growing the scope of electrical power sector day by day, so that UCP has connection with problem in the field of optimization, it has both continuous and binary variables which is the furthermost exciting problem that needs to be solved. In the proposed research, a newly created optimizer, i.e., Harris Hawks optimizer $(\mathrm{HHO})$, has been hybridized with sine-cosine algorithm (SCA) using memetic algorithm approach and named as meliorated Harris Hawks optimizer and it is applied to solve the photovoltaic constrained UCP of electric power system. In this research paper, sine-cosine Algorithm is used for provision of power generation (generating units which contribute in electric power generation for upload) and economic load dispatch (ELD) is completed by Harris Hawks optimizer. The feasibility and efficacy of operation of the hybrid algorithm are verified for small, medium power systems and large system considering renewable energy sources in summer and winter, and the percentage of cost saving for power generation is found. The results for 4 generating units, 5 generating units, 6 generating units, 7 generating units, 10 generating units, 19 generating units, 20 generating units, 40 generating units and 60 generating units are evaluated. The 10 generating units are evaluated with $5 \%$ and $10 \%$ spinning reserve. The efficacy of the offered optimizer has been verified for several standard benchmark problem including unit commitment problem, and it has been observed that the suggested optimizer is too effective to solve continuous, discrete and nonlinear optimization problems.
\end{abstract}

Keywords: Meta-heuristics, Harris Hawks optimizer, Unit commitment problem (UCP), Profit-based UCP, Economic load dispatch (ELD)

\section{Springer Open}

(o The Author(s) 2021. This article is licensed under a Creative Commons Attribution 4.0 International License, which permits use, sharing, adaptation, distribution and reproduction in any medium or format, as long as you give appropriate credit to the original author(s) and the source, provide a link to the Creative Commons licence, and indicate if changes were made. The images or other third party material in this article are included in the article's Creative Commons licence, unless indicated otherwise in a credit line to the material. If material is not included in the article's Creative Commons licence and your intended use is not permitted by statutory regulation or exceeds the permitted use, you will need to obtain permission directly from the copyright holder. To view a copy of this licence, visit http://creativeco mmons.org/licenses/by/4.0/. 


\section{Introduction}

Machine learning and artificial intelligence and so many problems are related to real world which have continuous and discrete behavior and constrained and unconstrained in nature. For this kind of attributes, there are a few challenges to handle a few sorts of issues utilizing traditional methodologies with scientific techniques [1]. A few sorts of research have tried that these all strategies are insufficient viable or effective to bargain numerous kinds of non-continuous problem and non-differentiable problem and furthermore in such huge numbers of real-world problem. In this way, meta-heuristic algorithm is considered and it is used to handle such a significant number of problems which are generally basic in nature and easily executed. Nowadays, the recent developed optimizer is Harris Hawks optimizer [HHO] [2]. Original version of Harris Hawks optimizer (HHO) had highlights that can in any case be improved as it might insight convergence problems or may effectively get caught in neighborhood optima [3]. Many variants had been developed which are discussed in Table 1 (a), which are used to improve or upgrade the existing HHO, so that the efficiency of the optimization techniques will be enhanced [4]. The procedure of optimization technique is proceeded till this can fulfill the most extreme iteration. In the present days, developing mindfulness and enthusiasm for effective, economical and fruitful utilization of such kinds of meta-heuristic calculation is under current examination. Modified version of existing algorithm was also upgraded by mutation to solve the real-world optimization problem also [5]. Nonetheless, after no free lunch theorem (NFL) [6], wide range for optimization dependent through enhancement methods prescribed and showed normal equal execution on the off chance that it is applied to every likely sort of errands dependent on optimization technique [7].

In the recent year, the electrical power sector is classified as huge proportions, vastly interconnected and highly nonlinear as dimension of electric power system is rising continuously due to huge electrical power demand in all the essential segment like commercial, agriculture, residential and industrial region. On electricity grid, the influence of overloading occurs due to rising the propensities in electrical load demand, privatization and deregulation taking place on electrical grids. For this condition, it needs progress of electric grid as the same step, as the rise in electric load demand and efficient power generation scheduling and commitment has the ability to regulate the time varying electrical load demand which is run for utilization of available grid [8]. Nowadays, recent power sector has some various sources of electrical power locations containing hydro-, thermal and nuclear power generation system; during a whole day, the electric power demand fluctuates with various peak values [9]. Thus, it is essential to determine that power generating units should be turned on, when necessary in power system network and the preparation or order in which the generating unit should kept in turn off condition is by considering the efficiency of cost for turn on and shut down for the respective power generating units. The whole procedure of constructing these assessments is known as unit commitment (UC) [10].

The main novelty of the proposed research work includes the hybrid variant of Harris Hawks optimizer, i.e., hybrid Harris Hawks-Sine-Cosine algorithm (hHHO-SCA) has been developed. The exploration phase of the existing Harris Hawks optimizer has been improved. A recently invented hybridized optimizer using memetic algorithm approach is used to solve unit commitment problem of power system. This paper offers 
Table 1 (a) Assessment of several heuristics and meta-heuristics search optimization techniques. (b) Literature survey of unit commitment. (c) Literature survey of wind power uncertainty. (d) Literature survey of solar uncertainty

\begin{tabular}{|c|c|c|c|}
\hline Reference Nos. & $\begin{array}{l}\text { Year } \\
\text { of publication }\end{array}$ & $\begin{array}{l}\text { Main findings or conclusion } \\
\text { relevant to proposed research } \\
\text { work }\end{array}$ & Algorithm name \\
\hline \multicolumn{4}{|l|}{ (a) } \\
\hline$[77]$ & 2020 & $\begin{array}{l}\text { mGWO optimizer was designed } \\
\text { to get suitable balance between } \\
\text { exploration and exploitation } \\
\text { phases. It was tested on IEEE CEC } \\
2017 \text { and IEEE CEC } 2014 \text { standard } \\
\text { functions. And it is also verified on } \\
\text { engineering design problem in } \\
\text { real-world and multilevel thresh- } \\
\text { olding problems }\end{array}$ & $\begin{array}{l}\text { Memory-based Gray Wolf Optimizer } \\
\text { [mGWO] }\end{array}$ \\
\hline$[1]$ & 2020 & $\begin{array}{l}\text { MG-SCA optimizer was imple- } \\
\text { mented to solve optimization } \\
\text { problems. It was verified on stand- } \\
\text { ard IEEE CEC } 2014 \text { benchmark } \\
\text { functions to check the efficiency } \\
\text { of this algorithm }\end{array}$ & $\begin{array}{l}\text { Memory-Guided Sine-Cosine Algo- } \\
\text { rithm [MG-SCA] }\end{array}$ \\
\hline$[78]$ & 2020 & $\begin{array}{l}\text { Orthogonally designed Adapted } \\
\text { Grasshopper Optimization was } \\
\text { designed to solve optimization } \\
\text { problem. It was tested on } 30 \text { IEEE } \\
\text { CEC2017 benchmarks to find } \\
\text { effectiveness of the meta-heuristic } \\
\text { algorithm }\end{array}$ & $\begin{array}{l}\text { Orthogonally designed Adapted } \\
\text { Grasshopper Optimization [OAGO] }\end{array}$ \\
\hline$[79]$ & 2020 & $\begin{array}{l}\text { A smart meta-heuristic algorithm } \\
\text { was implemented to solve engi- } \\
\text { neering design problems and it } \\
\text { was tested on } 15 \text { benchmark on } \\
\text { CEC } 2015 \text { by Wilcoxon's test and } \\
\text { statistical analysis. }\end{array}$ & $\begin{array}{l}\text { Smart Flower Optimization Algorithm } \\
\text { [SFOA] }\end{array}$ \\
\hline$[80]$ & 2020 & $\begin{array}{l}\text { Hybrid PSO and GWO algorithm was } \\
\text { designed to solve global optimiza- } \\
\text { tion problem }\end{array}$ & $\begin{array}{l}\text { Hybrid Crossover-Oriented PSO and } \\
\text { GWO [HC-PSOGWO] }\end{array}$ \\
\hline$[81]$ & 2020 & $\begin{array}{l}\text { Imperialist Competitive Learner- } \\
\text { Based Optimization was imple- } \\
\text { mented to solve engineering } \\
\text { design problem }\end{array}$ & $\begin{array}{l}\text { Imperialist Competitive Learner-Based } \\
\text { Optimization [ICLBO] }\end{array}$ \\
\hline$[82]$ & 2020 & $\begin{array}{l}\text { Barnacles Mating Optimizer was } \\
\text { designed to solve the problem } \\
\text { related to engineering optimiza- } \\
\text { tion }\end{array}$ & Barnacles Mating Optimizer [BMO] \\
\hline [83] & 2020 & $\begin{array}{l}\text { Equilibrium Optimizer was created } \\
\text { to solve optimization problems } \\
\text { and it was test on } 58 \text { unimodal, } \\
\text { multimodal, and composition } \\
\text { functions and three engineering } \\
\text { problems }\end{array}$ & Equilibrium Optimizer [EO] \\
\hline$[84]$ & 2020 & $\begin{array}{l}\text { Improved Fitness-Dependent Opti- } \\
\text { mizer Algorithm was designed and } \\
\text { tested on CEC2019 to validate its } \\
\text { feasibility to real-world problem }\end{array}$ & $\begin{array}{l}\text { Improved Fitness-Dependent Opti- } \\
\text { mizer Algorithm [IFDOA] }\end{array}$ \\
\hline$[85]$ & 2020 & $\begin{array}{l}\text { Spotted Hyena Optimizer based on } \\
\text { swarm based optimization in the } \\
\text { area of meta-heuristic research to } \\
\text { improve the exploratory search }\end{array}$ & Spotted Hyena Optimizer [SHO] \\
\hline$[86]$ & 2020 & $\begin{array}{l}\text { Improved Whale Optimization Algo- } \\
\text { rithm was designed with using the } \\
\text { mechanism of joint search to solve } \\
\text { the global optimization problems }\end{array}$ & $\begin{array}{l}\text { Improved Whale Optimization Algo- } \\
\text { rithm [IWOA] }\end{array}$ \\
\hline
\end{tabular}


Table 1 (continued)

\begin{tabular}{|c|c|c|c|}
\hline Reference Nos. & $\begin{array}{l}\text { Year } \\
\text { of publication }\end{array}$ & $\begin{array}{l}\text { Main findings or conclusion } \\
\text { relevant to proposed research } \\
\text { work }\end{array}$ & Algorithm name \\
\hline [87] & 2020 & $\begin{array}{l}\text { Multi-Strategy Enhanced Sine-- } \\
\text { Cosine Algorithm was calculated } \\
\text { to engineering design problem in } \\
\text { real world and improve the global } \\
\text { optimization }\end{array}$ & MSESCA \\
\hline [88] & 2020 & $\begin{array}{l}\text { Refined Selfish Herd Optimizer was } \\
\text { designed to solve global optimiza- } \\
\text { tion problem }\end{array}$ & Refined Selfish Herd Optimizer [RSHO] \\
\hline [89] & 2020 & $\begin{array}{l}\text { Hybrid Harris Hawks optimizer com- } \\
\text { bined with SCA was implemented } \\
\text { to get solutions of numerical } \\
\text { and engineering optimization } \\
\text { problems }\end{array}$ & $\begin{array}{l}\text { Intensify Harris Hawks Optimizer } \\
{[\mathrm{IHHO}]}\end{array}$ \\
\hline [75] & 2019 & $\begin{array}{l}\text { GLF-GWO was implemented } \\
\text { with leadership-based quality } \\
\text { to solve the global optimization } \\
\text { problem. The leadership quality } \\
\text { was improved by Levy flight (LF) } \\
\text { searching techniques. It was } \\
\text { tested on standard benchmark } \\
\text { functions including IEEE CEC } 2006 \\
\text { and IEEE CEC } 2014 \text {. }\end{array}$ & $\begin{array}{l}\text { leadership quality was improved by } \\
\text { Levy flight (LF) search and Gray Wolf } \\
\text { Optimizer [GLF-GWO] }\end{array}$ \\
\hline [76] & 2019 & $\begin{array}{l}\text { GWO optimizer had been modified } \\
\text { with DE to avoid trapped in local } \\
\text { optima and solve optimization } \\
\text { problems. It was verified on } 23 \\
\text { standard benchmarks }\end{array}$ & $\begin{array}{l}\text { Greedy differential evolution_Gray } \\
\text { Wolf Optimizer [gDE-GWO] }\end{array}$ \\
\hline [90] & 2019 & $\begin{array}{l}\text { A novel meta-heuristic optimizer, } \\
\text { Artificial Ecosystem-Based Opti- } \\
\text { mization was implemented to } \\
\text { resolve the problem related with } \\
\text { unidentified search space }\end{array}$ & $\begin{array}{l}\text { Artificial Ecosystem-Based Optimiza- } \\
\text { tion [AEBO] }\end{array}$ \\
\hline [91] & 2019 & $\begin{array}{l}\text { Incremental Gray Wolf Optimizer } \\
\text { and Expanded Gray Wolf Opti- } \\
\text { mizer were the improved version } \\
\text { of GWO which used to get solu- } \\
\text { tion for the global optimization } \\
\text { problem }\end{array}$ & $\begin{array}{l}\text { Incremental Gray Wolf Optimizer } \\
\text { and Expanded Gray Wolf Optimizer } \\
\text { [I-GWO and Ex-GWO] }\end{array}$ \\
\hline [92] & 2019 & $\begin{array}{l}\text { Life Choice-Based Optimizer was } \\
\text { considered to resolve optimization } \\
\text { problems and it was tested on six } \\
\text { CEC-2005 functions }\end{array}$ & life Choice-Based Optimizer [LCBO] \\
\hline [93] & 2019 & $\begin{array}{l}\text { Multi-objective technique was } \\
\text { invented to get solutions of the } \\
\text { problem related to truss method }\end{array}$ & $\begin{array}{l}\text { Multi-objective Heat Transfer Search } \\
\text { Algorithm [MHTSA] }\end{array}$ \\
\hline [94] & 2019 & $\begin{array}{l}\text { Simplified Salp Swarm Algorithm } \\
\text { was created to resolve the } \\
\text { optimization problem and it was } \\
\text { verified on } 23 \text { common bench- } \\
\text { mark to check the feasibility of this } \\
\text { technique }\end{array}$ & $\begin{array}{l}\text { Simplified Salp Swarm Algorithm } \\
\text { [SSSA] }\end{array}$ \\
\hline [95] & 2019 & $\begin{array}{l}\text { New method was designed and } \\
\text { tested on } 28 \text { numbers of standard } \\
\text { benchmark problem to solve } \\
\text { global Optimization problems }\end{array}$ & $\begin{array}{l}\text { Self-adaptive differential artificial bee } \\
\text { colony algorithm [SA-DABC] }\end{array}$ \\
\hline
\end{tabular}


Table 1 (continued)

\begin{tabular}{|c|c|c|c|c|c|c|c|}
\hline \multicolumn{2}{|c|}{ Reference Nos. } & \multicolumn{2}{|c|}{$\begin{array}{l}\text { Year } \\
\text { of publication }\end{array}$} & \multicolumn{2}{|c|}{$\begin{array}{l}\text { Main findings or conclusion } \\
\text { relevant to proposed research } \\
\text { work }\end{array}$} & \multicolumn{2}{|c|}{ Algorithm name } \\
\hline [73] & & 2018 & & \multicolumn{2}{|c|}{$\begin{array}{l}\text { Modified SCA technique was devel- } \\
\text { oped by opposition-based learn- } \\
\text { ing and added the self-adaptive } \\
\text { factor to solve the global optimiza- } \\
\text { tion problem in real world. It was } \\
\text { verified on } 23 \text { standard bench- } \\
\text { marks and IEEE CEC } 2014 \text { standard } \\
\text { test functions }\end{array}$} & \multicolumn{2}{|c|}{$\begin{array}{l}\text { Modified Sine-Cosine Algorithm } \\
\text { [m-SCA] }\end{array}$} \\
\hline [74] & & 2018 & \multicolumn{3}{|c|}{$\begin{array}{l}\text { SCA algorithm was improved with } \\
\text { crossover scheme to develop the } \\
\text { capability of exploitation to real- } \\
\text { world solve optimization problem. } \\
\text { It was tested on standard IEEE } \\
\text { CEC } 2014 \text { and IEEE CEC } 2017 \text { test } \\
\text { functions }\end{array}$} & \multicolumn{2}{|c|}{$\begin{array}{l}\text { Improved Sine-Cosine Algorithm } \\
\text { [ISCA] }\end{array}$} \\
\hline References & $\begin{array}{l}\text { Year } \\
\text { of } p\end{array}$ & ublication & $\begin{array}{l}\text { Ind } \\
\text { (Scc }\end{array}$ & $\begin{array}{l}\text { lexing of journal } \\
\text { opus/SCl index etc.) }\end{array}$ & $\begin{array}{l}\text { Main findings } \\
\text { or conclusion } \\
\text { to proposed r } \\
\text { work }\end{array}$ & relevant & Remarks \\
\hline \multicolumn{8}{|l|}{ (b) } \\
\hline [96] & \multicolumn{2}{|c|}{2019} & \multicolumn{2}{|c|}{$\begin{array}{l}\text { Science Citation Index } \\
\text { expanded }\end{array}$} & \multicolumn{2}{|c|}{$\begin{array}{l}\text { Comparative presenta- } \\
\text { tions on some bench- } \\
\text { mark instances were } \\
\text { analyzed }\end{array}$} & $\begin{array}{l}\text { Optimization of UCP were } \\
\text { solved including wrap- } \\
\text { around scheduling and } \\
\text { ramp-rate constraint }\end{array}$ \\
\hline [97] & \multicolumn{2}{|c|}{2019} & \multicolumn{2}{|c|}{ Science Citation Index } & \multicolumn{2}{|c|}{$\begin{array}{l}\text { IEEE-9 bus system was } \\
\text { applied to experi- } \\
\text { ment the capability of } \\
\text { technique considering } \\
\text { different objectives }\end{array}$} & $\begin{array}{l}\text { Resolution of optimum } \\
\text { electric power flow } \\
\text { based on mutual reac- } \\
\text { tive and active cost by } \\
\text { particle swarm optimiza- } \\
\text { tion [PSO] }\end{array}$ \\
\hline [98] & \multicolumn{2}{|c|}{2019} & \multicolumn{2}{|c|}{ Science Citation Index } & \multicolumn{2}{|c|}{$\begin{array}{l}\text { 4th, 5th, 6th, 7th, 10th, } \\
\text { 19th, 20th and 40th } \\
\text { gen. units test systems } \\
\text { were used to solve UCP } \\
\text { optimization problem. }\end{array}$} & $\begin{array}{l}\text { An optimum forceful } \\
\text { generation scheduling } \\
\text { by sine cosine algorithm } \\
\text { [SCA] }\end{array}$ \\
\hline [99] & \multicolumn{2}{|c|}{2019} & \multicolumn{2}{|c|}{ Science Citation Index } & \multicolumn{2}{|c|}{$\begin{array}{l}\text { Framework: Quantum } \\
\text { Inspired Binary Gray } \\
\text { Wolf Optimizer was } \\
\text { designed to solve UCP }\end{array}$} & FQIBGWO \\
\hline [100] & \multicolumn{2}{|c|}{2019} & \multicolumn{2}{|c|}{ Scopus } & \multicolumn{2}{|c|}{$\begin{array}{l}\text { An Improved DA-PSO } \\
\text { Optimization used to } \\
\text { solve UCP and the 5th, } \\
\text { 6th, 10th, and 26th } \\
\text { gen. units test systems } \\
\text { were applied to check } \\
\text { the efficacy of the sug- } \\
\text { gested research work }\end{array}$} & $\begin{array}{l}\text { Dragonfly algorithm was } \\
\text { joined with particle } \\
\text { swarm Optimization } \\
\text { [DA-PSO] }\end{array}$ \\
\hline [101] & \multicolumn{2}{|c|}{2018} & \multicolumn{2}{|c|}{ Science Citation Index } & \multicolumn{2}{|c|}{$\begin{array}{l}\text { Hybrid GWO combined } \\
\text { with RES technique } \\
\text { was designed to solve } \\
\text { UCP and it had been } \\
\text { tested on standard } 23 \\
\text { benchmark problems } \\
\text { and 7th, 10th, 19th, } \\
\text { 20th and 40th systems } \\
\text { taken to validate the } \\
\text { effectiveness of the } \\
\text { planned method }\end{array}$} & $\begin{array}{l}\text { Hybrid Gray wolf optimizer } \\
\text { combined with random } \\
\text { exploratory search tech- } \\
\text { nique [hGWO-RES] }\end{array}$ \\
\hline
\end{tabular}


Table 1 (continued)

\begin{tabular}{|c|c|c|c|c|}
\hline References & $\begin{array}{l}\text { Year } \\
\text { of publication }\end{array}$ & $\begin{array}{l}\text { Indexing of journal } \\
\text { (Scopus/SCl index etc.) }\end{array}$ & $\begin{array}{l}\text { Main findings } \\
\text { or conclusion relevant } \\
\text { to proposed research } \\
\text { work }\end{array}$ & Remarks \\
\hline [102] & 2017 & Scopus & $\begin{array}{l}\text { Gravitational Search } \\
\text { Algorithm was } \\
\text { designed to solve UCP } \\
\text { and the viability of the } \\
\text { suggested method } \\
\text { was tested on tested } \\
\text { on 10-generating unit } \\
\text { system later extended } \\
\text { up to 40-generating } \\
\text { unit test system with } \\
24 \text {-h time horizon }\end{array}$ & $\begin{array}{l}\text { Gravitational Search Algo- } \\
\text { rithm [GSA] }\end{array}$ \\
\hline \multirow[t]{2}{*}{ [103] } & 2016 & Scopus & $\begin{array}{l}\text { SFLA was created } \\
\text { for short duration } \\
\text { optimum schedule of } \\
\text { thermal power gen- } \\
\text { eration units including } \\
\text { prohibited }\end{array}$ & $\begin{array}{l}\text { Shuffled Frog Leaping } \\
\text { Algorithm [SFLA] }\end{array}$ \\
\hline & & & $\begin{array}{l}\text { Operational zone (poz) } \\
\text { constraints and emis- } \\
\text { sion limitation }\end{array}$ & \\
\hline [104] & 2016 & Scopus & $\begin{array}{l}\text { 4-, 10-, 20-, 40-, 80-, } \\
\text { 100-unit systems were } \\
\text { applied to check effec- } \\
\text { tiveness of research } \\
\text { work }\end{array}$ & $\begin{array}{l}\text { Advanced 3-stage method } \\
\text { to solve the UCP }\end{array}$ \\
\hline [105] & 2016 & Scopus & $\begin{array}{l}10 \text { generating units } \\
\text { considering } 24 \text {-h test } \\
\text { system was used to } \\
\text { check the effectiveness } \\
\text { of the research work }\end{array}$ & Fireworks Algorithm [FA] \\
\hline [106] & 2016 & Science Citation Index & $\begin{array}{l}\text { The suggested memetic } \\
\text { algorithm was veri- } \\
\text { fied for standard IEEE } \\
\text { benchmark containing } \\
\text { of } 4 \text { th, } 10 \text { th, 20th and } \\
\text { 40th power generat- } \\
\text { ing unit }\end{array}$ & Harmony Search [HS] \\
\hline [107] & 2016 & Scopus & $\begin{array}{l}\text { WIC-PSO was designed } \\
\text { to solve UCP and effi- } \\
\text { cacy and viability of the } \\
\text { suggested technique } \\
\text { were verified on system } \\
\text { considering and not } \\
\text { including additional } \\
\text { pumped storage plant. }\end{array}$ & $\begin{array}{l}\text { Weighted-Improved Crazy } \\
\text { Particle Swarm Optimiza- } \\
\text { tion [WIC-PSO] }\end{array}$ \\
\hline [108] & 2015 & Scopus & $\begin{array}{l}\text { PSO was useful to reduce } \\
\text { total operating price } \\
\text { and exploit total ben- } \\
\text { efit. Here } 12 \text { scenarios } \\
\text { had been measured in } \\
\text { the existence of battery } \\
\text { banks and without } \\
\text { them in } 2 \text { operating } \\
\text { modes: grid-connected } \\
\text { mode and stand-alone } \\
\text { mode }\end{array}$ & $\begin{array}{l}\text { Here-and-Now [HN] } \\
\text { approach in battery } \\
\text { banks (BBs) }\end{array}$ \\
\hline
\end{tabular}


Table 1 (continued)

\begin{tabular}{|c|c|c|c|c|}
\hline References & $\begin{array}{l}\text { Year } \\
\text { of publication }\end{array}$ & $\begin{array}{l}\text { Indexing of journal } \\
\text { (Scopus/SCl index etc.) }\end{array}$ & $\begin{array}{l}\text { Main findings } \\
\text { or conclusion relevant } \\
\text { to proposed research } \\
\text { work }\end{array}$ & Remarks \\
\hline [106] & 2015 & Science Citation Index & $\begin{array}{l}\text { Hybrid HS-random } \\
\text { search technique was } \\
\text { invented to resolve } \\
\text { single-area UCP and } \\
\text { the suggested method } \\
\text { had been verified on } \\
\text { standard IEEE systems } \\
\text { containing of 4th, 10th, } \\
\text { 20th and 40th units to } \\
\text { check the efficacy of } \\
\text { the method. }\end{array}$ & $\begin{array}{l}\text { Hybrid Harmony Search- } \\
\text { Random Search algo- } \\
\text { rithm [hHS-RES] }\end{array}$ \\
\hline [109] & 2015 & $\begin{array}{l}\text { Science Citation Index } \\
\text { expanded }\end{array}$ & $\begin{array}{l}\text { Demand Response Based } \\
\text { approach including } \\
\text { ramp rate constraints } \\
\text { was designed to solve } \\
\text { large scale UCP }\end{array}$ & Demand response [DR] \\
\hline [110] & 2015 & Science Citation Index & $\begin{array}{l}\text { A hybrid DE-RS optimiza- } \\
\text { tion technique was } \\
\text { designed to solve unit } \\
\text { commitment problem } \\
\text { and it was tested } \\
\text { on IEEE benchmark } \\
\text { systems consisting of } 4 \\
\text { unit, } 10 \text { unit, 20th and } \\
\text { 40th test systems }\end{array}$ & $\begin{array}{l}\text { hybrid DE-Random Search } \\
\text { [hDE-RS] }\end{array}$ \\
\hline [111] & 2015 & Science Citation Index & $\begin{array}{l}\text { A new hybrid PSO-GWO } \\
\text { method was imple- } \\
\text { mented to solve UCP } \\
\text { and it was tested on } \\
\text { 30-bus system, 14-bus } \\
\text { system and 10th power } \\
\text { generation model }\end{array}$ & hybrid PSO-GWO \\
\hline [112] & 2015 & $\begin{array}{l}\text { Science Citation Index } \\
\text { expanded }\end{array}$ & $\begin{array}{l}56 \mathrm{MW} 1 \text { gas turbine and } \\
1 \text { steam turbine, } 2 \mathrm{~L} 2 \\
\text { gas turbines, } 530 \mathrm{MW} \\
\text { and } 1 \text { steam turbine } \\
\text { and } 530 \mathrm{MW}, 1 \text { steam } \\
\text { turbine and } 3 \mathrm{LR}-2 \\
\text { gas turbines were } \\
\text { considered to examina- } \\
\text { tion the viability of the } \\
\text { research }\end{array}$ & $\begin{array}{l}\text { The proposed research } \\
\text { work analyzed the signifi- } \\
\text { cance of certain design } \\
\text { including construction. }\end{array}$ \\
\hline [113] & 2015 & Science Citation Index & $\begin{array}{l}\text { 10th power gen. unit was } \\
\text { considered to checked } \\
\text { the efficacy of the } \\
\text { research }\end{array}$ & $\begin{array}{l}\text { Distributed power systems } \\
\text { (DPSs) with IRESs }\end{array}$ \\
\hline [114] & 2015 & Scopus & $\begin{array}{l}\text { 3rd and 8th gen. units } \\
\text { were considered to } \\
\text { check the efficacy of } \\
\text { the research as taken } \\
\text { for the wind power } \\
\text { predicting errors. }\end{array}$ & $\begin{array}{l}\text { Fuzzy Chance-Constrained } \\
\text { Program [FCCP] }\end{array}$ \\
\hline [115] & 2015 & $\begin{array}{l}\text { Science Citation Index } \\
\text { expanded }\end{array}$ & $\begin{array}{l}10,20,30,40,60,80,100 \\
\text { unit system were } \\
\text { applied to check effec- } \\
\text { tiveness of research } \\
\text { work }\end{array}$ & $\begin{array}{l}\text { Binary Artificial Bee Colony } \\
\text { Algorithm [BABCA] }\end{array}$ \\
\hline
\end{tabular}


Table 1 (continued)

\begin{tabular}{|c|c|c|c|c|}
\hline References & $\begin{array}{l}\text { Year } \\
\text { of publication }\end{array}$ & $\begin{array}{l}\text { Indexing of journal } \\
\text { (Scopus/SCl index etc.) }\end{array}$ & $\begin{array}{l}\text { Main findings } \\
\text { or conclusion relevant } \\
\text { to proposed research } \\
\text { work }\end{array}$ & Remarks \\
\hline [116] & 2014 & Scopus & $\begin{array}{l}\text { Improved Shuffled Frog } \\
\text { Leaping procedure was } \\
\text { considered to solve } \\
\text { UCP considering a } \\
\text { constrained including } \\
\text { multi objective com- } \\
\text { bined emission }\end{array}$ & $\begin{array}{l}\text { Improved Shuffled Frog } \\
\text { Leaping Algorithm } \\
\text { [ISFLA] }\end{array}$ \\
\hline [117] & 2014 & Science Citation Index & $\begin{array}{l}\text { To authenticate the } \\
\text { viability and efficacy of } \\
\text { the submitted method } \\
\text { (BGSA) to solve UCP, } \\
\text { the suggested BGSA } \\
\text { was verified on dissimi- } \\
\text { lar systems size created } \\
\text { on basic systems of } \\
\text { 10th gen. unit, 20th, } \\
\text { 40th, 60th, 80th and } \\
\text { 100th gen. unit }\end{array}$ & $\begin{array}{l}\text { BGSA with the Lambda- } \\
\text { Iteration technique was } \\
\text { applied and the data } \\
\text { regarding system load } \\
\text { and wind power predic- } \\
\text { tion were collected }\end{array}$ \\
\hline [117] & 2014 & Science Citation Index & $\begin{array}{l}\text { Model of thermal UCP } \\
\text { with wind power addi- } \\
\text { tion was recognized } \\
\text { and constrain program- } \\
\text { ming was useful to } \\
\text { mimic the special } \\
\text { belongings of wind } \\
\text { power variation. }\end{array}$ & Founds TUCPW model \\
\hline [118] & 2014 & $\begin{array}{l}\text { Science Citation Index } \\
\text { expanded }\end{array}$ & $\begin{array}{l}\text { Validate the ability of } \\
\text { used the algorithm to } \\
\text { solve the UCP, it was } \\
\text { applied on a 10-, 20-, } \\
\text { 40-, 60-, } 80-\text { and } 100 \\
\text { unit systems }\end{array}$ & $\begin{array}{l}\text { Dynamic technique for } \\
\text { probabilistic charge of } \\
\text { power generator inac- } \\
\text { cessibility was planned }\end{array}$ \\
\hline [119] & 2013 & Science Citation Index & $\begin{array}{l}\text { Cuckoo Search Algorithm } \\
\text { was implemented to } \\
\text { solve UCP and model } \\
\text { power system includ- } \\
\text { ing } 10 \text { power plant } \\
\text { with generating units } \\
\text { had been used in this } \\
\text { study }\end{array}$ & $\begin{array}{l}\text { Cuckoo Search Algorithm } \\
\text { [CSA] }\end{array}$ \\
\hline [120] & 2013 & Science Citation Index & $\begin{array}{l}\text { Classical model of the } \\
\text { Dynamic Combined } \\
\text { Economic-environ- } \\
\text { mental was imple- } \\
\text { mented for optimum } \\
\text { power generation } \\
\text { scheduling in the } \\
\text { electricity market with } \\
\text { consideration of } \\
\text { availability of power } \\
\text { generation units }\end{array}$ & $\begin{array}{l}\text { Multi-objective-based } \\
\text { Genetic Algorithm }\end{array}$ \\
\hline [121] & 2012 & Scopus & $\begin{array}{l}10,20,40,60,80,100 \text { unit } \\
\text { test system were used }\end{array}$ & $\begin{array}{l}\text { Variable Neighborhood } \\
\text { Search [VNS] }\end{array}$ \\
\hline
\end{tabular}


Table 1 (continued)

\begin{tabular}{|c|c|c|c|c|}
\hline References & $\begin{array}{l}\text { Year } \\
\text { of publication }\end{array}$ & $\begin{array}{l}\text { Indexing of journal } \\
\text { (Scopus/SCl index etc.) }\end{array}$ & $\begin{array}{l}\text { Main findings } \\
\text { or conclusion relevant } \\
\text { to proposed research } \\
\text { work }\end{array}$ & Remarks \\
\hline [122] & 2012 & Science Citation Index & $\begin{array}{l}\text { Shuffled Frog Leap- } \\
\text { ing Algorithm was } \\
\text { designed to solve UCP. } \\
\text { To validate the enact- } \\
\text { ment of the suggested } \\
\text { method was useful for } \\
\text { standard IEEE 14-, 30-, } \\
\text { 56-, 118-slandered bus } \\
\text { and 10th gen. test unit, } \\
\text { 20th gen. test unit for } \\
\text { 1-day forecast period }\end{array}$ & $\begin{array}{l}\text { Shuffled Frog Leaping } \\
\text { Algorithm [SFL] }\end{array}$ \\
\hline \multicolumn{5}{|l|}{ (c) } \\
\hline [123] & 2018 & Scopus & $\begin{array}{l}\text { Multi-objective GA } \\
\text { method was invented } \\
\text { to find optimal solution } \\
\text { for UCP including low- } \\
\text { est emission. }\end{array}$ & $\begin{array}{l}\text { Multi-objective GA was } \\
\text { used and data regarding } \\
\text { load demand consider- } \\
\text { ing renewable energy } \\
\text { schedule are collected } \\
\text { from the proposed } \\
\text { research work. }\end{array}$ \\
\hline [124] & 2018 & Science Citation Index & $\begin{array}{l}\text { FCUCP technique was } \\
\text { designed to solve } \\
\text { UCP considering wind } \\
\text { power generation } \\
\text { including ramp limit }\end{array}$ & $\begin{array}{l}\text { Frequency-Constrained } \\
\text { Unit Commitment Prob- } \\
\text { lem [FCUCP] was used to } \\
\text { solve UCP and Forecast } \\
\text { wind power data are col- } \\
\text { lected for day ahead }\end{array}$ \\
\hline [125] & 2018 & $\begin{array}{l}\text { Science Citation Index } \\
\text { expanded }\end{array}$ & $\begin{array}{l}\text { ABC-CSA for cost } \\
\text { assessment consider- } \\
\text { ing wind power were } \\
\text { implemented and } \\
\text { the effectiveness had } \\
\text { been tested in IEEE } 30 \\
\text { buses of six genera- } \\
\text { tor test systems with } \\
\text { 10-generating unit test } \\
\text { systems }\end{array}$ & $\begin{array}{l}\text { Artificial Bee Colony } \\
\text { and Cuckoo Search } \\
\text { Algorithm [ABC-CSA] } \\
\text { were applied and cost } \\
\text { estimated data were } \\
\text { collected }\end{array}$ \\
\hline [126] & 2016 & Scopus & $\begin{array}{l}\text { MTLBO technique was } \\
\text { invented to solve UCP } \\
\text { by using standard IEEE } \\
\text { ten-unit test system } \\
\text { and 26-unit reliability } \\
\text { test system }\end{array}$ & $\begin{array}{l}\text { Modified Teaching-Learn- } \\
\text { ing-Based Optimization } \\
\text { algorithm [MTLBO] }\end{array}$ \\
\hline [127] & 2016 & $\begin{array}{l}\text { Science Citation Index } \\
\text { expanded }\end{array}$ & $\begin{array}{l}\text { MDE method was useful } \\
\text { to solve unit commit- } \\
\text { ment problematic } \\
\text { considering impact of } \\
\text { plug-in EVs }\end{array}$ & $\begin{array}{l}\text { Modified Differential Evolu- } \\
\text { tion [MDE] }\end{array}$ \\
\hline [128] & 2016 & Science Citation Index & $\begin{array}{l}\text { BASA technique was } \\
\text { implemented to solve } \\
\text { unit commitment } \\
\text { problem including } \\
\text { renewable energy } \\
\text { sources and hydro } \\
\text { electric energy pump } \\
\text { storage }\end{array}$ & $\begin{array}{l}\text { BASA was used and data of } \\
\text { forecasted wind power } \\
\text { and photovoltaic power } \\
\text { has been collected from } \\
\text { the proposed research } \\
\text { work }\end{array}$ \\
\hline [129] & 2016 & Scopus & $\begin{array}{l}\text { IEEE 118-bus test system } \\
\text { with } 54 \text { power gen- } \\
\text { erating units used to } \\
\text { validate the proposed } \\
\text { method }\end{array}$ & $\begin{array}{l}\text { Artificial Computational } \\
\text { Intelligence }[\mathrm{ACl}] \text { was } \\
\text { used }\end{array}$ \\
\hline
\end{tabular}


Table 1 (continued)

\begin{tabular}{|c|c|c|c|c|}
\hline References & $\begin{array}{l}\text { Year } \\
\text { of publication }\end{array}$ & $\begin{array}{l}\text { Indexing of journal } \\
\text { (Scopus/SCl index etc.) }\end{array}$ & $\begin{array}{l}\text { Main findings } \\
\text { or conclusion relevant } \\
\text { to proposed research } \\
\text { work }\end{array}$ & Remarks \\
\hline [130] & 2015 & Science Citation Index & $\begin{array}{l}\text { The proposed research } \\
\text { work had been imple- } \\
\text { mented about the col- } \\
\text { lective and individual } \\
\text { impact of } 3 \text { DERs, } \\
\text { including generation } \\
\text { for wind power, EDRP } \\
\text { and PEV on unit com- } \\
\text { mitment. }\end{array}$ & $\begin{array}{l}\text { Data regarding energy } \\
\text { price and hourly electric- } \\
\text { ity demand considering } \\
\text { hourly electric vehicle } \\
\text { power in charging and } \\
\text { discharging mode were } \\
\text { collected }\end{array}$ \\
\hline [114] & 2015 & Scopus & $\begin{array}{l}\text { A fuzzy technique was } \\
\text { used to solve UCP has } \\
\text { taken load demand } \\
\text { retort, EVs and wind } \\
\text { power }\end{array}$ & $\begin{array}{l}\text { Data collection for load } \\
\text { demand considering } \\
\text { wind power }\end{array}$ \\
\hline [131] & 2015 & Science Citation Index & $\begin{array}{l}\text { The proposed research } \\
\text { work was implemented } \\
\text { to find out the PDF of a } \\
\text { resolute commitment } \\
\text { of power generators } \\
\text { or not. }\end{array}$ & Priority List (PL) method \\
\hline [132] & 2014 & Science Citation Index & $\begin{array}{l}\text { The proposed research } \\
\text { method was used to } \\
\text { solve UCP including } \\
\text { pumped hydro energy } \\
\text { storage and wind } \\
\text { power }\end{array}$ & $\begin{array}{l}\text { Constraints of pumped } \\
\text { storage power plant } \\
\text { were collected }\end{array}$ \\
\hline [117] & 2014 & Science Citation Index & $\begin{array}{l}\text { To authenticate the } \\
\text { viability and efficacy of } \\
\text { the submitted method } \\
\text { (BGSA) to solve UCP, } \\
\text { the recommended } \\
\text { method was verified } \\
\text { on various system }\end{array}$ & $\begin{array}{l}\text { BGSA with the Lambda- } \\
\text { Iteration method was } \\
\text { applied and the data } \\
\text { regarding system load } \\
\text { and wind power predic- } \\
\text { tion were collected }\end{array}$ \\
\hline [133] & 2013 & Scopus & $\begin{array}{l}\text { LR-PSO Method was } \\
\text { designed to solve } \\
\text { scheduling of power } \\
\text { generation problem } \\
\text { for thermal, wind-solar } \\
\text { system for deregulated } \\
\text { electrical power system }\end{array}$ & LR-PSO Method \\
\hline \multicolumn{5}{|l|}{ (d) } \\
\hline [134] & 2018 & Science Citation Index & $\begin{array}{l}\text { Optimum scheduling } \\
\text { for unit commitment } \\
\text { problem considering } \\
\text { photovoltaic insecurity } \\
\text { and suitable power } \\
\text { of EVs and output } \\
\text { showed the reduction } \\
\text { of production cost and } \\
\text { improved load flow. }\end{array}$ & $\begin{array}{l}\text { Collection of data regard- } \\
\text { ing hourly evidence of } \\
\text { solar power on the day } \\
\text { of summer and winter } \\
\text { day. Also collected data } \\
\text { for UC without PV, UC } \\
\text { with PV and PEV, PEV ano } \\
\text { UC with PEV. }\end{array}$ \\
\hline [135] & 2018 & Science Citation Index & $\begin{array}{l}\text { Priority-based method } \\
\text { was designed to solve } \\
\text { stochastic UCP consid- } \\
\text { ering parking lot coop- } \\
\text { eration and renewable } \\
\text { energy sources }\end{array}$ & Priority-based method \\
\hline
\end{tabular}


Table 1 (continued)

\begin{tabular}{|c|c|c|c|c|}
\hline References & $\begin{array}{l}\text { Year } \\
\text { of publication }\end{array}$ & $\begin{array}{l}\text { Indexing of journal } \\
\text { (Scopus/SCl index etc.) }\end{array}$ & $\begin{array}{l}\text { Main findings } \\
\text { or conclusion relevant } \\
\text { to proposed research } \\
\text { work }\end{array}$ & Remarks \\
\hline [136] & 2018 & Scopus & $\begin{array}{l}\text { Dynamic programming } \\
\text { technique was used } \\
\text { to discover realistic } \\
\text { conditions of power } \\
\text { generating units, while } \\
\text { consecutive quad- } \\
\text { ratic programming } \\
\text { algorithm was applied } \\
\text { for ELD of committed } \\
\text { gen. units }\end{array}$ & $\begin{array}{l}\text { Energy storage facilities } \\
\text { [ESF] }\end{array}$ \\
\hline [137] & 2017 & Science Citation Index & $\begin{array}{l}\text { Cooperative Multi-Swarm } \\
\text { PSO was used to solve } \\
\text { UCP under Photovol- } \\
\text { taic Generation includ- } \\
\text { ing day-ahead prices }\end{array}$ & $\begin{array}{l}\text { Cooperative Multi-Swarm } \\
\text { PSO }\end{array}$ \\
\hline [138] & 2016 & Science Citation Index & $\begin{array}{l}\text { Addition of renew- } \\
\text { able energy, power } \\
\text { generation indecisions } \\
\text { into stochastic nature } \\
\text { of unit commitment } \\
\text { considering risk and } \\
\text { reserve }\end{array}$ & SCUC \\
\hline [139] & 2016 & Science Citation Index & $\begin{array}{l}\text { The proposed method } \\
\text { was invented to solve } \\
\text { UCP considering pres- } \\
\text { ence of discontinuous } \\
\text { renewable energy } \\
\text { resources }\end{array}$ & $\begin{array}{l}\text { Proposed research work } \\
\text { helps to gain knowledge } \\
\text { about the benefits of the } \\
\text { present methodologies } \\
\text { avoiding the obtainable } \\
\text { weaknesses }\end{array}$ \\
\hline [140] & 2016 & $\begin{array}{l}\text { Science Citation Index } \\
\text { expanded }\end{array}$ & $\begin{array}{l}\text { Proposed research work } \\
\text { was designed to solve } \\
\text { UCP considering solar } \\
\text { power system. IEEE } 39 \\
\text { bus system and fore- } \\
\text { casted solar radiation } \\
\text { with } 24 \text { h load demand } \\
\text { had been taken to } \\
\text { validate }\end{array}$ & $\begin{array}{l}\text { Collection of data regard- } \\
\text { ing solar irradiance data } \\
\text { for } 150 \mathrm{MW} \text { power plant }\end{array}$ \\
\hline [141] & 2015 & Scopus & $\begin{array}{l}\text { The proposed research } \\
\text { work was based on } \\
\text { function approxima- } \\
\text { tion methodology of } \\
\text { reinforcement learning } \\
\text { to solve UCP with } \\
\text { photovoltaic energy } \\
\text { sources }\end{array}$ & $\begin{array}{l}\text { The research work pro- } \\
\text { posed a Neural Network } \\
\text { based Reinforcement } \\
\text { Learning method [NNRL] }\end{array}$ \\
\hline [113] & 2015 & Science Citation Index & $\begin{array}{l}\text { 10th generating power } \\
\text { systems unit was } \\
\text { applied to check the } \\
\text { efficacy of the research }\end{array}$ & $\begin{array}{l}\text { A whole computational } \\
\text { outline of addition con- } \\
\text { sidering quantification of } \\
\text { vacillations in DPSs with } \\
\text { IRESs }\end{array}$ \\
\hline [142] & 2014 & Science Citation Index & $\begin{array}{l}\text { BRCFF technique was } \\
\text { implemented to solve } \\
\text { security-constrained } \\
\text { UCP considering solar } \\
\text { power }\end{array}$ & $\begin{array}{l}\text { Binary Real Coded Firefly } \\
\text { (BRCFF) }\end{array}$ \\
\hline [143] & 2008 & Scopus & $\begin{array}{l}\text { GA functioned PSO } \\
\text { method was designed } \\
\text { to solve UCP consider- } \\
\text { ing wind and solar } \\
\text { Energy Systems }\end{array}$ & $\begin{array}{l}\text { [GA-PSO] Genetic Algo- } \\
\text { rithm operated Particle } \\
\text { Swarm Optimization }\end{array}$ \\
\hline
\end{tabular}


the resolution of unit commitment optimization problems of the power system by using the hybrid algorithm, as UCP is linked optimization as it has both binary and continuous variables; the strategy adopted to tackle both variables is different. In this paper, the proposed sine-cosine algorithm searches allocation of generators (units that participate in generation to take upload) and once units are decided, allocation of generations (economic load dispatch) is done by Harris Hawks optimizer. The feasibility and efficacy of operation of the hybrid algorithm are verified for small, medium power systems and large system considering renewable energy sources in summer and winter and the percentage of cost saving for power generation is found. The results for 4 generating units, 5 generating units, 6 generating units, 7 generating units, 10 generating units, 19 generating units, 20 generating units, 40 generating units and 60 generating units are evaluated. The 10 generating units are evaluated with $5 \%$ and $10 \%$ spinning reserve.

\section{Survey of literature}

In the field of research area, the optimization method is the vastest region of research through which the research works are effectively moving forward. Nowadays, researchers are working with multiple works for various problems using different techniques and they are capable of measuring the output successfully. To discover the new algorithms, the research work is on successfully running condition and to mitigate the drawbacks of present existing techniques.

Some of the research works in the field of optimization include ant colony optimization (ACO) algorithm [11], ant lion optimizer (ALO) [12], adaptive gbest-guided search algorithm (AGG) [13], bat algorithm (BA) [14], biogeography-based optimization (BBO) [15], branch and bound (BB) [16], binary bat algorithm (BBA) [17], bird swarm algorithm (BSA) [18], bacterial foraging optimization algorithm (BFOA) [19], backtracking search optimization (BSO) [20], and binary gravitational search algorithm (BGSA) [21], colliding bodies optimization (CBO) [22], cuckoo search algorithm (CS) [23], chaotic krill herd algorithm (CKHA) [24], cultural evolution algorithm (CEA) [25], dragonfly algorithm (DA) [26], dynamic programming (DP) [27], earthworm optimization algorithm (EOA) [28], elephant herding optimization (EHO) [29], electromagnetic field optimization (EFO) [30], exchange market algorithm (EMA) [31], forest optimization algorithm (FOA) [32], fireworks algorithm (FA) [33], flower pollination algorithm (FPA) [34], gravitational search algorithm (GSA) [35], genetic algorithm (GA) [36], firefly algorithm (FFA) [37], grasshopper optimization algorithm (GOA) [38], gray wolf optimizer (GWO) [39], human group optimizer (HGO) [40], Hopfield method [41], interior search algorithm (ISA) [42], imperialist competitive algorithm (ICA) [43], krill herd algorithm (KHA) [44], invasive weed optimization (IWO) [45], lightning search algorithm (LSA) [46], league championship algorithm (LCA) [47], multi-verse optimizer (MVO) [48], mixed integer programming (MIP) [49], mine blast algorithm (MBA) [50], moth-flame optimization (MFO) [51], simulated annealing (SA) [52], monarch butterfly optimization (MBO) [53], particle swarm optimization (PSO) [54], random walk gray wolf optimizer (RW-GWO) [55], optics inspired optimization (OIO) [56], runner-root algorithm (RRA) [57], sine-cosine algorithm (SCA) [58], shuffled frog-leaping algorithm (SFLA) [59], stochastic fractal search (SFS) [60],seeker optimization algorithm (SOA) [61], teaching-learning-based optimization (TLBO) [62], symbiotic organisms search (SOS) 
[63], search group algorithm (SGA) [64], salp swarm algorithm (SSA) [65], and whale optimization algorithm (WOA) [66], weighted superposition attraction (WSA) [67], virus colony search (VCS) [68], water wave optimization (WWO) [69], Tabu search (TS) [70], water cycle algorithm (WCA) [71], wind-driven optimization (WDO) [72], modified sine-cosine algorithm [m-SCA] [73], and improved sine-cosine algorithm [ISCA] [74]. Leadership quality was improved by Levy flight (LF) search and gray wolf optimizer [GLF-GWO] [75], greedy differential evolution-gray wolf optimizer [gDE-GWO] [76], memory-based gray wolf optimizer [mGWO] [77], and memory-guided sine-cosine algorithm [MG-SCA] [1].

Faisal Rahiman Pazheri et al. presented scheduling of power station with energy storage facility. Utilities of power are stimulated by converting the present conventional power plant into hybrid power plant by installing available energy storage facilities and renewable electric power unit to come across the sudden increase in the power demand. Facility of energy storage maintains a level of the penetration of renewable power to $10 \%$ of required load demand throughout the period of operation for hybrid power plant [136]. Chandrasekaran et al. proposed FF algorithm to get solution of the SUC problem for thermal/solar power sector considering issues regarding smart grid. The research paper included some critical review on reliable impacts of major resources of smart grid considering demand response (DR) and solar energy. Thus, it was essential to implement method for an integration of thermal and solar generating system [144]. Selvakumar et al. implemented a new strategy for solving unit commitment problem for thermal units integrated with solar energy system. There would be changes in the cost of power generation considered solar energy. The main objective was reduction of total production price for the electricity generating unit, and this paper also explained the variances by considering solar energy and non-considering the solar power [140]. Senjyu et al. proposed a new method using genetic algorithm operated PSO to solve the thermal UCP considering wind and solar energy system. This method was able to minimize production cost and produce high-quality solutions [143]. Ma et al. discussed about appliances scheduling via cooperative multi-swarm PSO under photovoltaic (PV) generation and day-ahead prices. This research work studied about the problem including scheduling appliances in residential system unit. The model of an appliance-scheduling was established for home energy management system which was based on day-ahead electricity price and PV generation [137]. Abujarad et al. discussed a review on current methods for commitment of generating unit in existence of irregular renewable energy resource [139]. Maryam Shahbazitabar and Hamdi Abdi implemented a new priority-based stochastic unit commitment as parking lot cooperation and renewable energy sources. This paper discussed about the fastest nature of heuristic method which was established on list of priority selections to get solution for stochastic nature of the problem related to unit commitment and useful to simple 10 unit systems where the study was addition considering electrical vehicles parking allocation considering wind farm and solar farm over 24-h time horizon [135]. Quan et al. proposed a comparative review on integrated renewable energy generation uncertainties which were captured by list of prediction intervals, into stochastic unit commitment considering reserve and risk [138]. Jasmin et al. implemented an optimization technique about reinforcement 
learning to solve unit commitment problem considering photovoltaic sources. For stochastic behavior of the associated power and solar irradiance, the arrangement of the different types of power generating sources considering solar energy turned to be an optimization problem stochastic in nature. This paper discussed about the optimization technique and reinforcement learning that can provide uncertainty of the environment of the nature which is very effective [141]. Saniya Maghsudlu and Sirus Mohammadi proposed a method to solve the problem in optimum schedule of commitment unit as appropriate control of EVs and PV uncertainty. The meta-heuristic approach, cuckoo search algorithm, was developed by greatest convergence speed to attain the optimal solution and get solution of UCP. The research discussed about case study of IEEE 10 unit system which was used to examine the impact of PV and PEVs on scheduling of generating unit [134].

\section{Problematic design}

The generating power is distributed along with utilities of generator scheduling which will meet the time varying load demand for a specific time period known as unit commitment problem (UCP). The main objective of UCP is minimization of the overall cost for production considering different system constraints. The overall costs of production including sum of shutdown cost and start-up cost, cost of fuel are given below:

$$
\min (\mathrm{TFC})=\sum_{t=1}^{H} \sum_{n=1}^{N}\left\{F_{\operatorname{cost} n}\left(P_{n t}\right)+\mathrm{SUC}_{n, t}+\mathrm{SDC}_{n t}\right\}
$$

The total cost of fuel over the scheduled time span ' $t$ ' is:

$$
\begin{aligned}
& \mathrm{TFC}=\sum_{t=1}^{T} \sum_{n=1}^{\mathrm{NU}}\left[F_{\text {cost }} \times U_{n, t}+\mathrm{SUC}_{n, t}\left(1-U_{n,(t-1)}\right) \times U_{n, t}\right] \\
& \mathrm{TFC}=\sum_{t=1}^{T} \sum_{n=1}^{\mathrm{NU}}\left[\left(A_{n} P_{n}^{2}+B_{n} P_{n}+C_{n}\right) \times U_{n, t}+\mathrm{SUC}_{n, t}\left(1-U_{n,(t-1)}\right) \times U_{n, t}\right]
\end{aligned}
$$

Here, cost for fuel $F_{\operatorname{costn} n}\left(P_{n t}\right)$ is stated as quadratic design that is mostly worked by researchers, also named as equation of convex function.

The cost of fuel of $(n)$ unit at $(t)$ hour can be mathematically represented as an equation which is given below:

$$
F_{\text {cost }}\left(P_{n}\right)=A_{n} P_{n}^{2}+B_{n} P_{n}+C_{n}
$$

where $A_{n}, B_{n}$ and $C_{n}$ are represented as coefficients of cost that may expressed as $\$ / \mathrm{h}, \$$ / $\mathrm{MWh}$, and $\$ / \mathrm{MWh}^{2}$ correspondingly.

Start-up cost can mathematically be represented by step function which is given below:

$$
\mathrm{SUC}_{n, t}==\left\{\begin{array}{lll}
\mathrm{HSU}_{n} ; & \text { for } \quad T_{n}^{\mathrm{DW}} \leq T_{n}^{\mathrm{UP}} \leq\left(T_{n}^{\mathrm{DW}}+T_{n}^{\mathrm{COLD}}\right) \\
\mathrm{CSU}_{n} ; & \text { for } & T_{n}^{\mathrm{UP}}>\left(T_{n}^{\mathrm{DW}}+T_{n}^{\mathrm{COLD}}\right)
\end{array} \quad(n \in \mathrm{NU} ; \quad t=1,2,3, \ldots, T)\right.
$$


Usual value of the shutdown cost for standard system is denoted as zero, and this can be established as fixed cost followed by the equation number (5).

$$
\mathrm{SDC}_{n t}=\mathrm{KP}_{n t}
$$

where $\mathrm{K}$ is represented as incremental cost for shutdown.

It is subjected through some constraints followed by (1) system constraints and (2) unit constraints.

\section{Constraints for system}

System constrains are interrelated with all generating unit existing in the systems. The systems constrains are characterized into two types like:

\section{Power balance or load balance constraints}

In power system, the constraint including power balance or load balance is more important parameter consisting of summation of whole committed generating unit at $t$ th time span which must be larger than or equivalent to the power demand for the particular time span ' $t$ '

$$
\sum_{n=1}^{\mathrm{NU}} P_{n, t} \times U_{n, t}=\mathrm{PD}_{n} .
$$

\section{Spinning reserve (SR) constraints}

Reliability of the system can be considered as facility of extra capability of power generation that is more important to deed instantly when failure occurred due to sudden change in load demand for such power generating unit which is already running. The extra capability of power generation is recognized as spinning reserve which is exactly represented as (Fig. 1):

$$
\sum_{n=1}^{\mathrm{NU}} P_{n, t}^{\mathrm{MAX}} \times U_{n, t} \geq \mathrm{PD}_{t}+\mathrm{SR}_{t} .
$$

\section{Constraints for power generating unit}

The specific constraints related to particular power generating unit existing in the systems are called generating unit constraint which are given as:

\section{Thermal unit constraints}

Thermal power units are controlled manually. This type of unit needs to undertake the change of temperature gradually, so it takes certain time span to take the generating unit accessible. Some crew members are essential to execute the maintenance and procedure of some thermal power generating units.

\section{Minimum up time}

This constraint is defined here as the minimum period of time previously the unit can be start over when the unit has already been shut down which is mathematically defined as: 


$$
T_{n, t}^{\mathrm{ON}} \geq T_{n}^{\mathrm{UP}}
$$

where $T_{n, t}^{\mathrm{ON}}$ is defined as interval through which the generating unit $\mathrm{n}$ is constantly ON (in hours) and $T_{n}^{\mathrm{UP}}$ is defined as minimum up time (in hours) for the generating unit $n$ (Fig. 1).

\section{Minimum down time}

When the power generating units will be DE-committed, there is required least period of time for recommitment of the unit which is mathematically given as:

$$
T_{n, t}^{\mathrm{OFF}} \geq T_{n}^{\mathrm{DW}}
$$

where $T_{n, t}^{\mathrm{OFF}}$ is time period for which generating unit $\mathrm{n}$ is constantly OFF (in hours) and $T_{n}^{\mathrm{DW}}$ is denoted as minimum down time (in hours) for the unit.

Adequate minimum downtime and uptime repair by heuristic mechanism accepted at those stages are stated in Fig. 2.

\section{Maximum and minimum power generating limits}

All power generating units have its individual maximum/minimum electric power generating limit, below and outside which it cannot produce, and this is known as maximum and minimum power limits, which is mathematically written as:

$$
P_{n}^{\mathrm{MIN}} \leq P_{n, t} \leq P_{n}^{\mathrm{MAX}}
$$

\section{Initial status for operation of electrical units}

For every units, the initial operating position must proceed as the day's earlier generation schedule is taken into consideration; thus, each and all generating units can fulfill its lowest downtime/uptime (Figs. 3, 4, 5, 6, 7).

$$
\begin{aligned}
& \begin{array}{l}
\text { Step 1: Sort the generators in descending order of maximum generating capacity. } \\
\text { Step 2: for } n=1 \text { to } N G \\
\text { if } U_{n, t}=0 \\
\text { then } U_{n, t}=1 \\
\quad \text { else if } T_{n, t}^{O F F}>M D T_{n} \\
\text { then } T_{n, t}^{O N}=T_{n, t-1}^{O N}+1 \\
\text { and } T_{n, t}^{O F F}=0
\end{array} \\
& \text { Step 3: Verify new generating power of units. } \\
& \text { Step 4: if } \sum_{n=1}^{N G} P_{n, t}^{M A X} U_{n, t} \geq P D_{n}+S R_{n} \text { then stop the algorithm, else go to step-2 } \\
& \text { Step 5: if } T_{n, t}^{O F F}<M D T_{n} \text { then do } l=t-T_{n, t}^{O F F}+1 \text { and set } u_{n, t}=1 \\
& \text { Step 6: Calculate } T_{n}^{l}=T_{n, l-1}^{O N}+1 \text { and } T_{n, t}^{O F F}=0 \\
& \text { Step 7: if } 1>t \text {, Verify generator output power for } \sum_{n=1}^{N G} P_{n, t}^{M A X} U_{n, t} \geq P D_{t}+S R_{n} \text {, else } \\
& \text { increment } 1 \text { by } 1 \text { and go to step-5 }
\end{aligned}
$$

Fig. 1 PSEUDO code of SR repairing 


$$
\begin{aligned}
& \text { for } \quad t=1 \text { to } T \\
& \text { if } t=1 \\
& \text { Compute } T_{t}^{O N}=T_{t 0}^{O N} U_{n, t}+U_{n, t}^{\prime} \\
& \text { Compute } T_{t}^{O F F}=\left(T_{t 0}^{O F F}\right) \overline{T_{t}^{O N}}+\overline{T_{t}^{O N}} \\
& \text { else } \\
& \text { Compute } T_{t}^{O N}=T_{t-1}^{O N} U_{n, t}^{\prime}+U_{n, t}^{\prime} \bar{~} \\
& \text { Compute } T_{n}^{O F F}=\left(T_{n-1}^{O F F}\right) \overline{T_{n}^{O N}}+\overline{T_{n}^{O N}} \\
& \text { end } \\
& \text { end }
\end{aligned}
$$

Fig. 2 PSEUDO code for MUD/MUT constraints

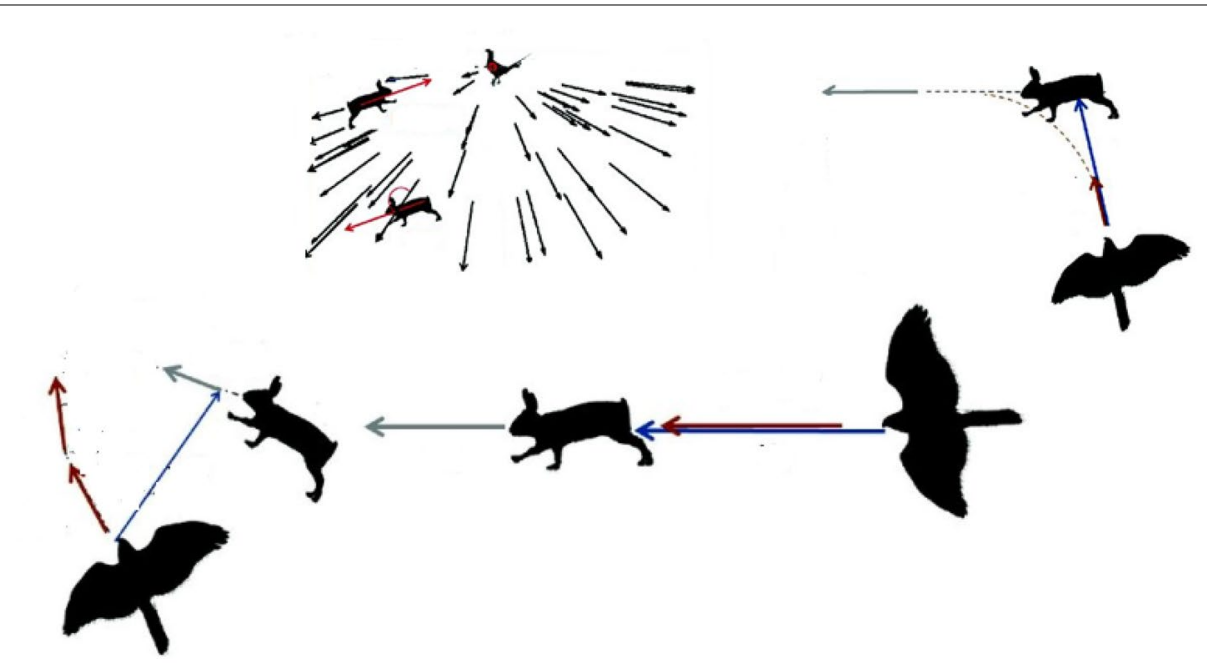

Fig. 3 Surprise attack

\section{Crew constraint}

When any power plant consists of more than one units, they could not turn on at the same period of time. So there need more than one crew member to attend such units in the same time while starting up.

\section{Unit accessibility constraint}

The constraint shows accessibility of power generating unit surrounded by any of the resulting various circumstances:
(A) Accessible or Not Accessible.
(B) Must Out or Outage.
(C) Must Run. 


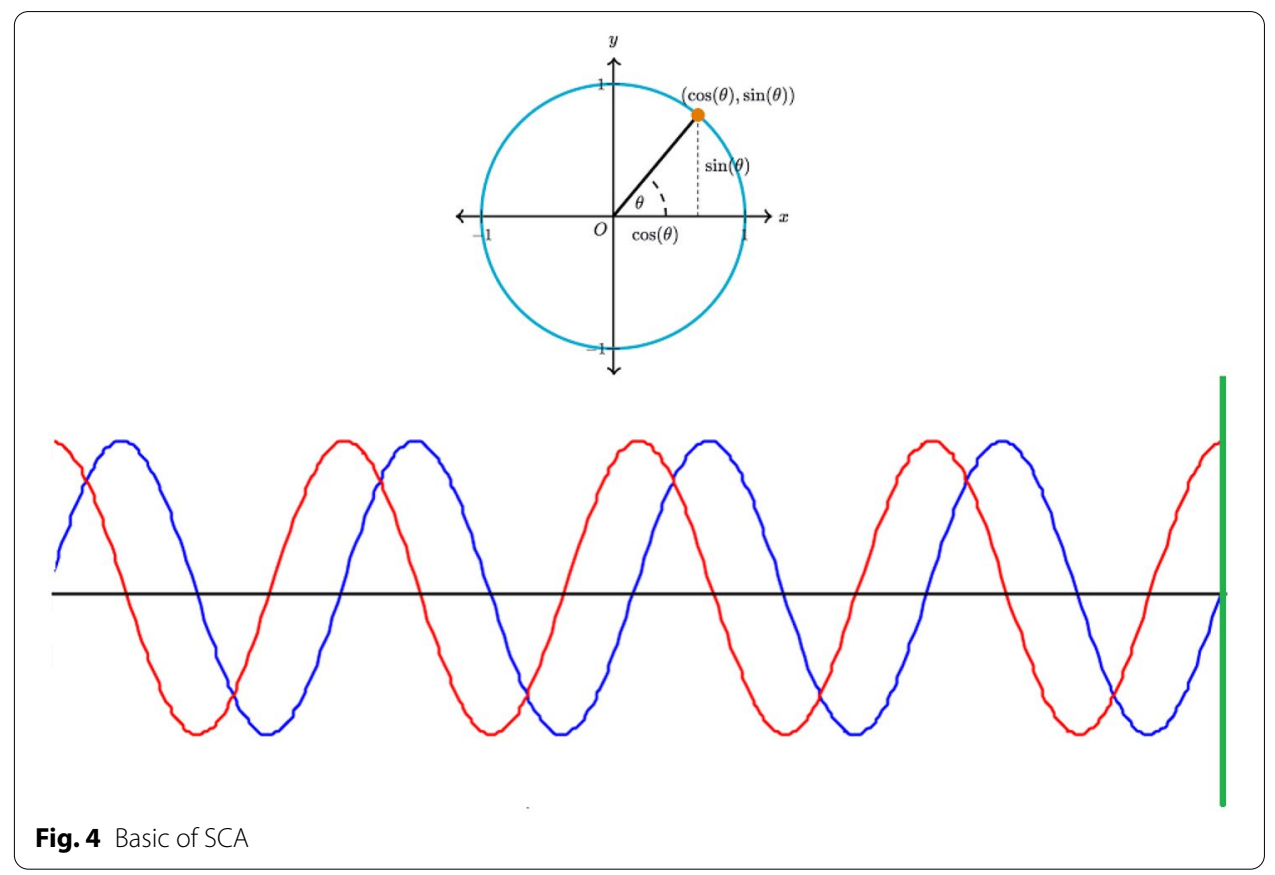

\section{Initial status of power generation unit}

It signifies value of initial grade of power generating unit. Its favorable rate signifies the position of current generating unit which is already in up condition, which means that numeral time periods of the generating units are already up, and if its negative value is an index of the integer of hours, then the generating unit has been already in down condition. The position of the generating unit \pm earlier the first hour through the schedule is an essential feature to define whether its latest situation interrupts the constraint of $T_{n}^{\mathrm{UP}}$ and $T_{n}^{\mathrm{DW}}$.

\section{Methods}

The mathematical formulation of the Harris Hawks optimizer has been explained in this section. The position updating mechanism of the harris hawks optimizer has been presented in Eqs. (11), (12) and (13). Presently, considering the equivalent possibility $w$ for each adjusting system depends upon areas for additional individuals to approach sufficiency while confronting as a prey, given in Eq. (11) (Figs. 3 and 4)

$$
\begin{aligned}
& X(\text { iteration }+1)=\left\{X_{\text {rand }}(\text { iteration })-r_{1} \times \text { abs }\left(X_{\text {rand }}(\text { iteration })-2 \times r_{2} \times X(\text { iteration })\right)\right\} ; \quad w \geq .5 \\
& X(\text { iteration }+1)=\left\{\left(X_{\text {rabbit }}(\text { iteration })-X_{m}(\text { iteration })\right)-r_{3} \times\left(\mathrm{LB}+r_{4} \times(\mathrm{UB}-\mathrm{LB})\right)\right\} ; \quad w<.5 \\
& X_{m}(\text { iteration })=\frac{1}{N}\left(\sum_{i=1}^{N} X_{i}(\text { iteration })\right)
\end{aligned}
$$

where $r_{1}, r_{2}, r_{3}, r_{4}$, and $w$ are random records in the middle of $(0,1)$; those are upgraded in every cycle, $X($ iteration +1$)$ is denoted as Rabbit's position and $N$ is defined as total amount of Harris hawks

Normal area for Harris Hawks is accomplished utilizing Eq. (13) (Fig. 5). 


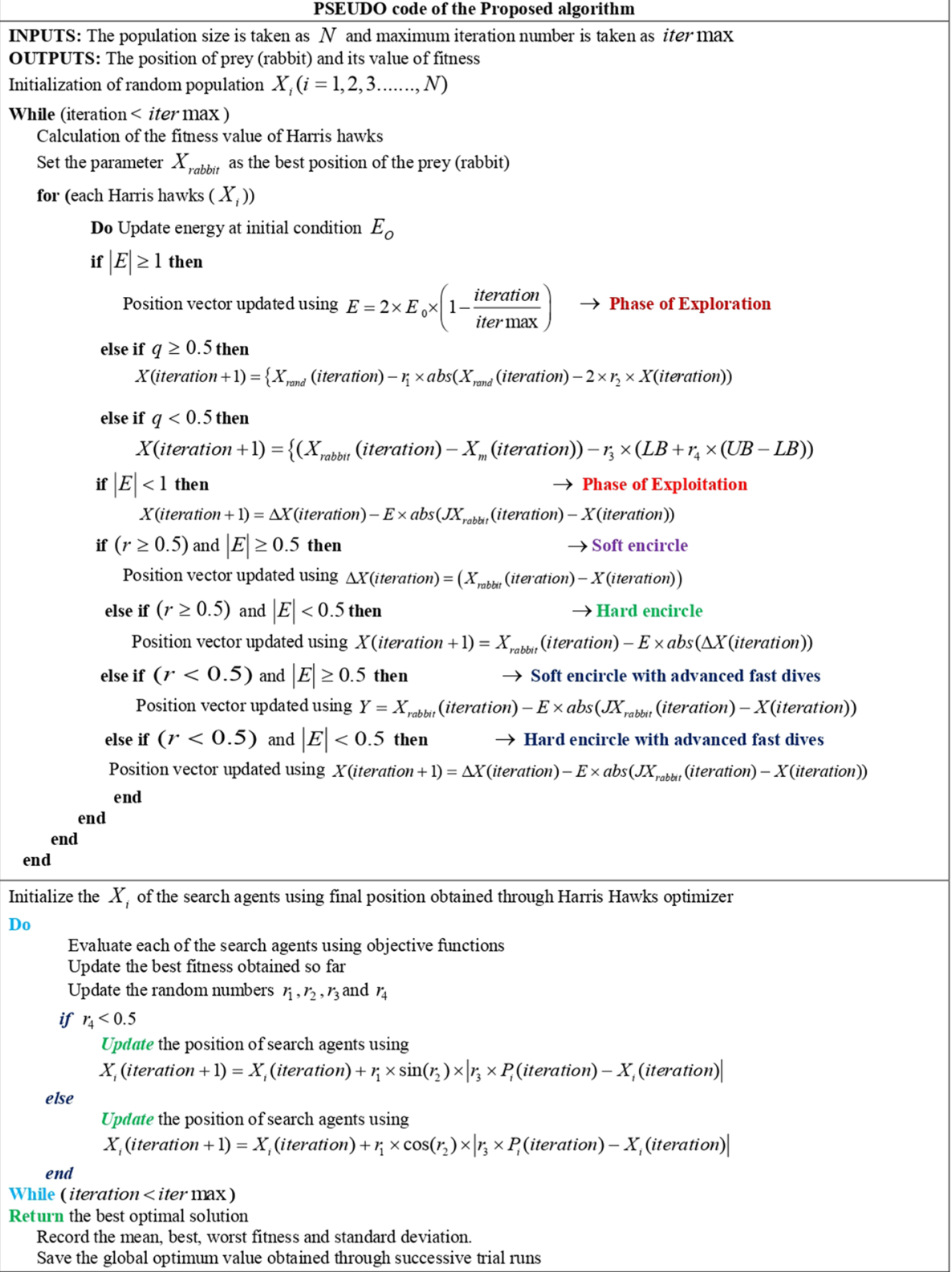

Fig. 5 a Pseudocode of proposed hybrid hHHO-SCA algorithm. b Flowchart for hHHO-SCA technique

Change after the period for investigation of the period of exploitation is shown:

$$
E=2 \times E_{0} \times\left(1-\frac{\text { iteration }}{\text { itermax }}\right)
$$

where $E$ is the avoidance energy for rabbit, $E_{0}$ the early condition for energy and itermax $=$ maximum iteration

$$
X(\text { iteration }+1)=\Delta X(\text { iteration })-E \times a b s\left(J X_{\text {rabbit }}(\text { iteration })-X(\text { iteration })\right)
$$




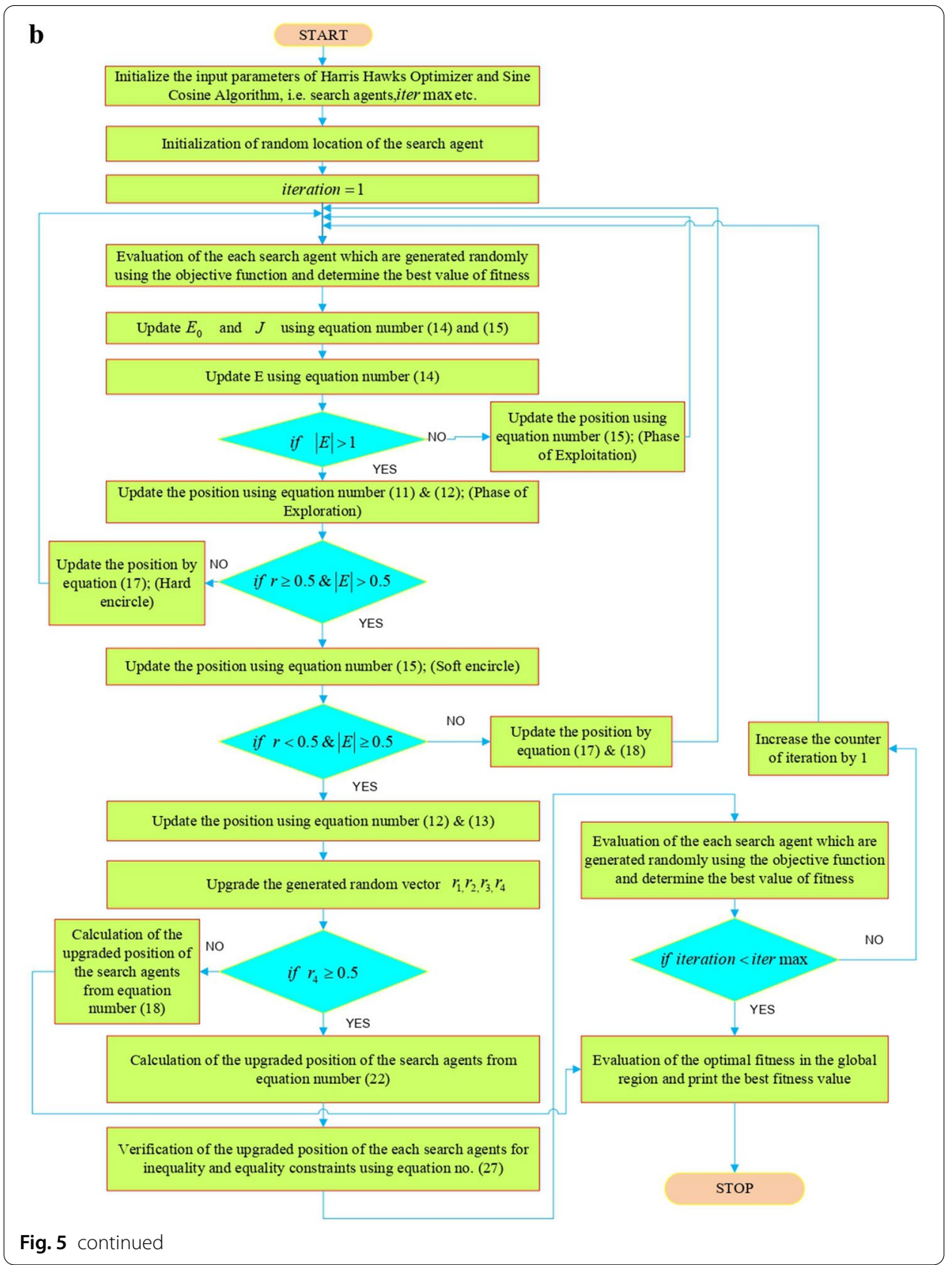

$\Delta X($ iteration $)=\left(X_{\text {rabbit }}(\right.$ iteration $)-X($ iteration $\left.)\right)$

$X($ iteration +1$)=X_{\text {rabbit }}($ iteration $)-E \times a b s(\Delta X($ iteration $))$

$Y=X_{\text {rabbit }}($ iteration $)-E \times a b s\left(J X_{\text {rabbit }}(\right.$ iteration $)-X($ iteration $\left.)\right)$

$Z=Y+S \times L F(D)$. 


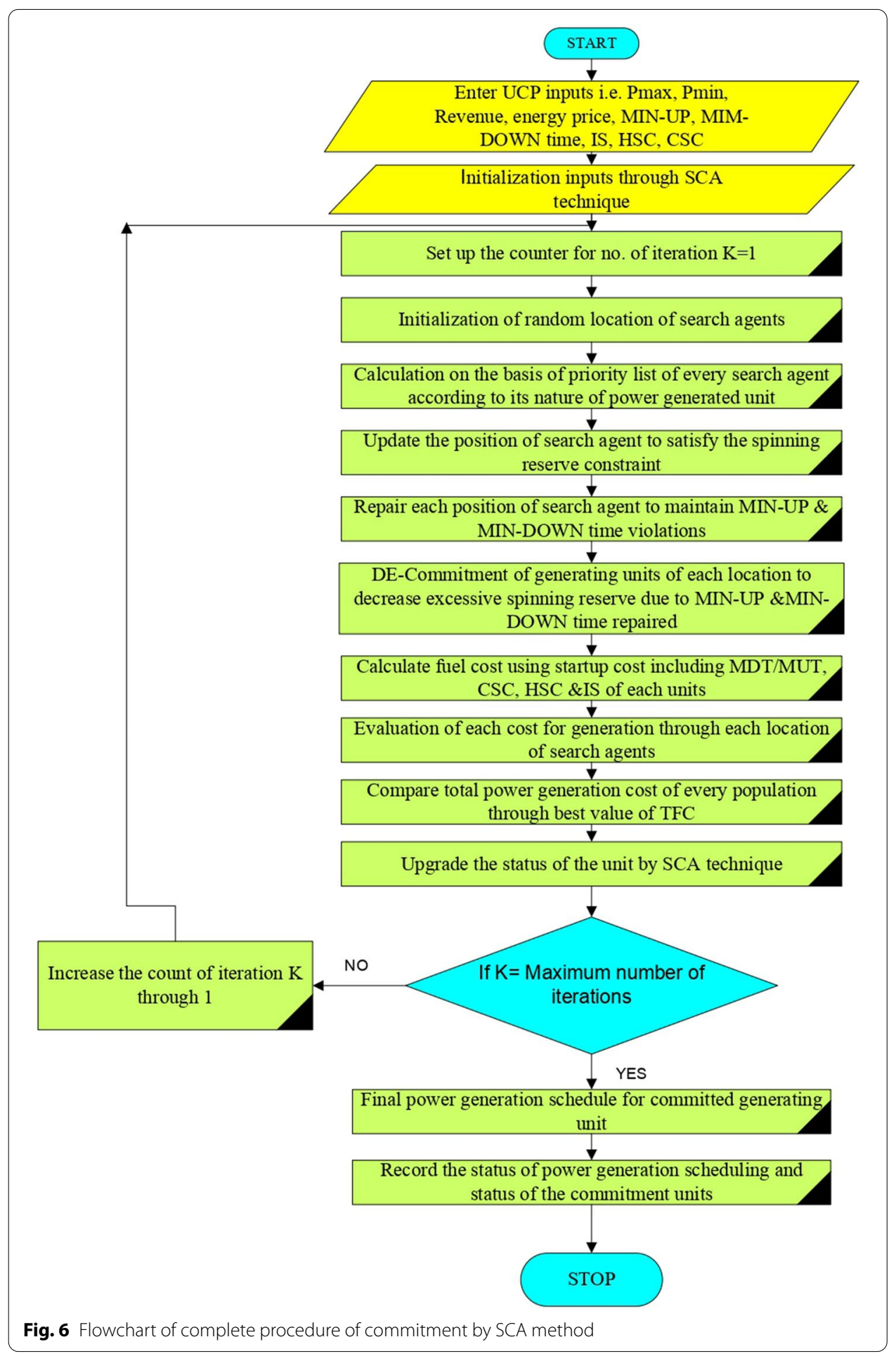

Along these lines, to find out the better solution of a soft enclose, the Hawks birds of prey are able to choose their development $Y$ that depends upon standard that is shown in Eq. (18)

Established $L f(D)$ patterns are constructed which track the given instruction in Eq. (20), 


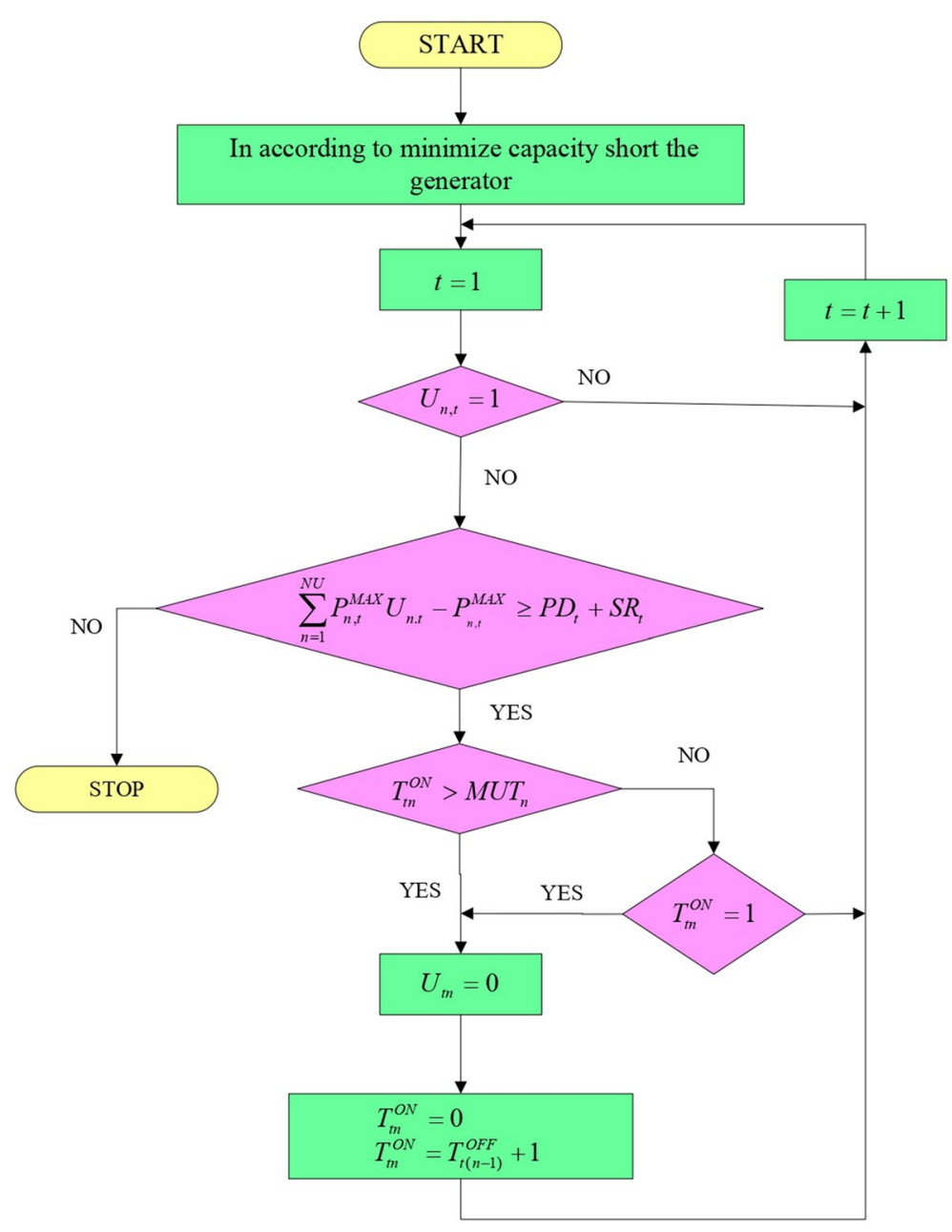

Fig. 7 Flowchart of handle minimum uptime-downtime constraints

where $D=$ dimension of problems, $S=$ dimension of random vectors with size $1 \times D$

$$
\begin{aligned}
& L F(x)=0.01\left(\frac{\mu \times \sigma}{|\nu|^{\frac{1}{\beta}}}\right) \\
& \sigma=\left(\frac{\Gamma(1+\beta) \times \sin \left(\frac{\pi \beta}{2}\right)}{\Gamma\left(\frac{1+\beta}{2}\right) \times \beta \times 2\left(\frac{\beta-1}{2}\right)}\right)^{\frac{1}{\beta}}
\end{aligned}
$$

where $\mu, \sigma$ are denoted as such kind of values randomly in between $(0,1)$ and $\beta$ set to 1.5 which is a constant known as default.

The final and actual positions through this period of soft encircle can be updated using Eqs. (22) and (23) shown below: 


$$
\begin{aligned}
& X(\text { iteration }+1)=\left\{\begin{array}{l}
Y ; \text { if } F(Y)<F(X(\text { iteration })) \\
Z ; \text { if } F(Z)<F(X(\text { iteration }))
\end{array}\right. \\
& Y=X_{\text {rabbit }}(\text { iteration })-E \times \operatorname{abs}\left(J X_{\text {rabbit }}(\text { iteration })-X_{m}(\text { iteration })\right) \\
& Z=Y+S \times L f(D)
\end{aligned}
$$

$X_{m}$ (iteration) can be obtained from Eq. (23).

The SCA optimization technique is mathematically written as:

$$
\begin{aligned}
& X_{i}(\text { iteration }+1)=X_{i}(\text { iteration })+r_{1} \times \sin \left(r_{2}\right) \times \mid r_{3} \times P_{i}(\text { iteration })-X_{i}(\text { iteration }) \mid \\
& X_{i}(\text { iteration }+1)=X_{i}(\text { iteration })+r_{1} \times \cos \left(r_{2}\right) \times \mid r_{3} \times P_{i}(\text { iteration })-X_{i}(\text { iteration }) \mid \\
& X_{i}(\text { iteration }+1)=\left\{\begin{array}{l}
X_{i}(\text { iteration })+r_{1} \times \sin \left(r_{2}\right) \times \mid r_{3} \times P_{i}(\text { iteration })-X_{i}(\text { iteration }) \mid ; \text { if } r_{4}<0.5 \\
X_{i}(\text { iteration })+r_{1} \times \cos \left(r_{2}\right) \times \mid r_{3} \times P_{i}(\text { iteration })-X_{i}(\text { iteration }) \mid ; \text { if } r_{4} \geq 0.5
\end{array}\right.
\end{aligned}
$$

Here, $r_{4}$ is denoted as random numbers $[0,1]$.

This method based on the suggested process may balance exploitation as well as exploration to get favorable solutions in the area of search space and lastly meet to find global optimal solutions using Eq. (27) (Fig. 6).

$$
r_{1}=\left(2-\text { iteration } \times \frac{2}{\text { Itermax }}\right)
$$

\section{Handling of spinning reserve constraints}

The simple possible solution that was obtained by SCA technique is highly unsuccessful to satisfy spinning reserve necessity (Fig. 7). Also handling of minimum uptime and downtime leads to extra spinning reserve. Thus, it is compulsory to handle/adjust spinning reserve necessity heuristically. The flowchart in Fig. 8 explains whole process to repair spinning reserve necessity.

\section{De-committing of excess of units}

It is obvious from the code given over that during fix of MDT, MUT, and spinning reserve we need to take generating unit status "ON" if these requirements are violated by putting it off. Since we do as such against the caution given by algorithm, obliviously

it brings about additional save. This circumstance is exceptionally unwanted; thus, we need to recommit some of the units once again in order to archive economic operation. In the following, the heuristic methodology is received for de-committing the additional spinning reserve (Figs. 9, 10). 


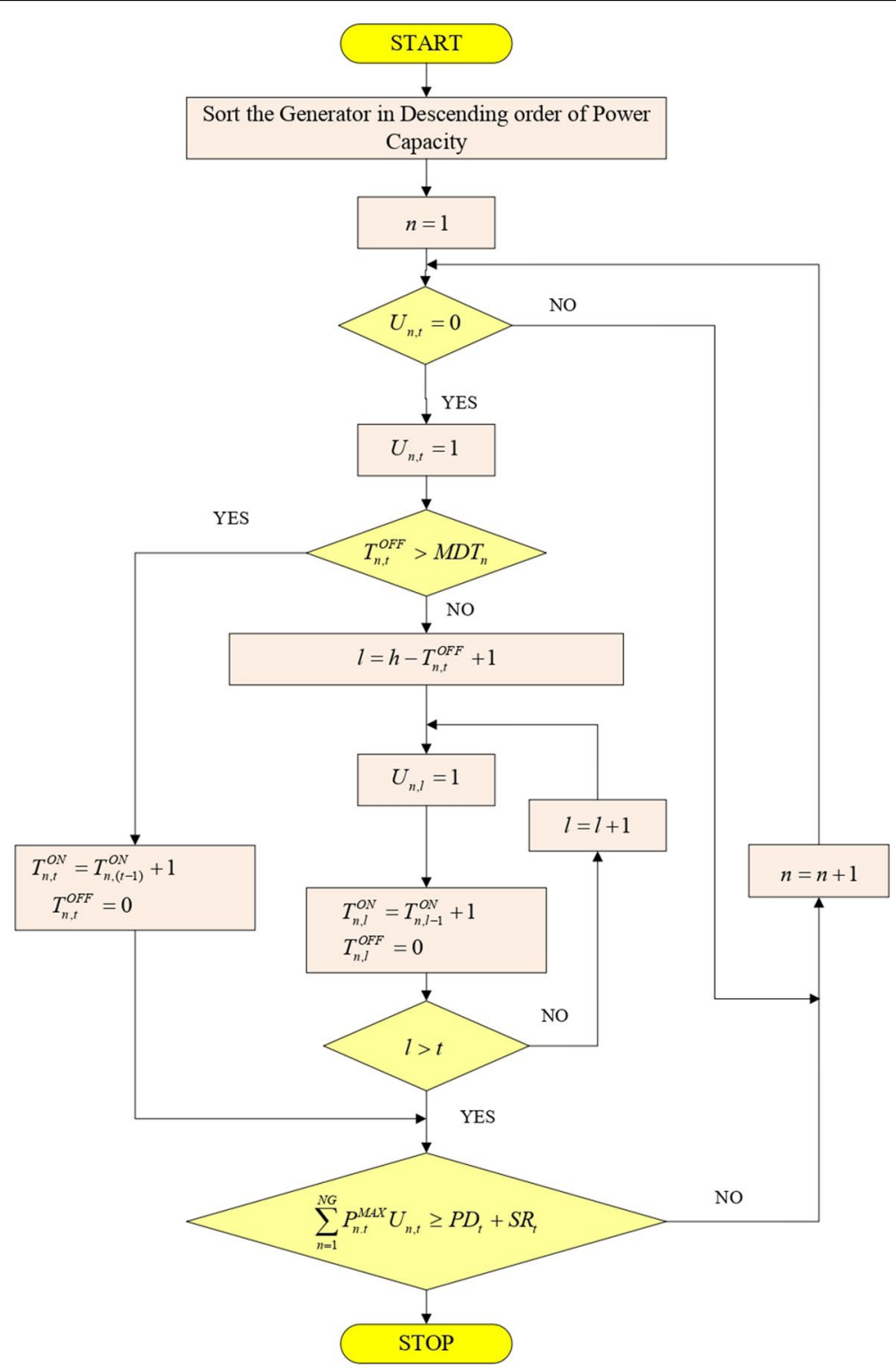

Fig. 8 Flowchart for repairing spinning reserve

\section{Results and discussion}

In order to validate the efficacy of the hHHO-SCA optimization technique, the outcomes of hHHO-SCA algorithm have been given below. The generating units' data are shown in Additional file 1: Annexure-A1 to A6 and its comparative analysis considering 


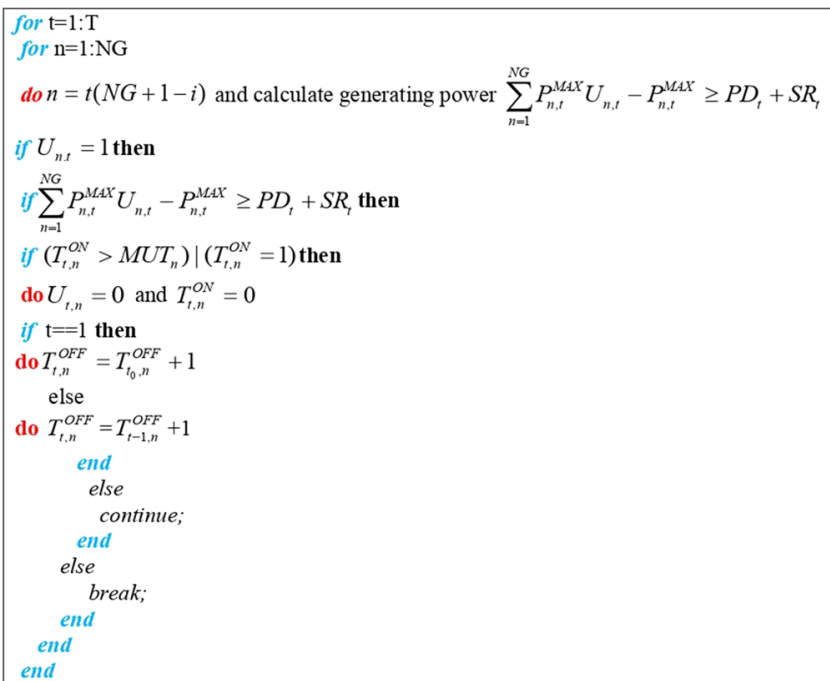

Fig. 9 Pseudocode of decommitment for excessive power generating unit

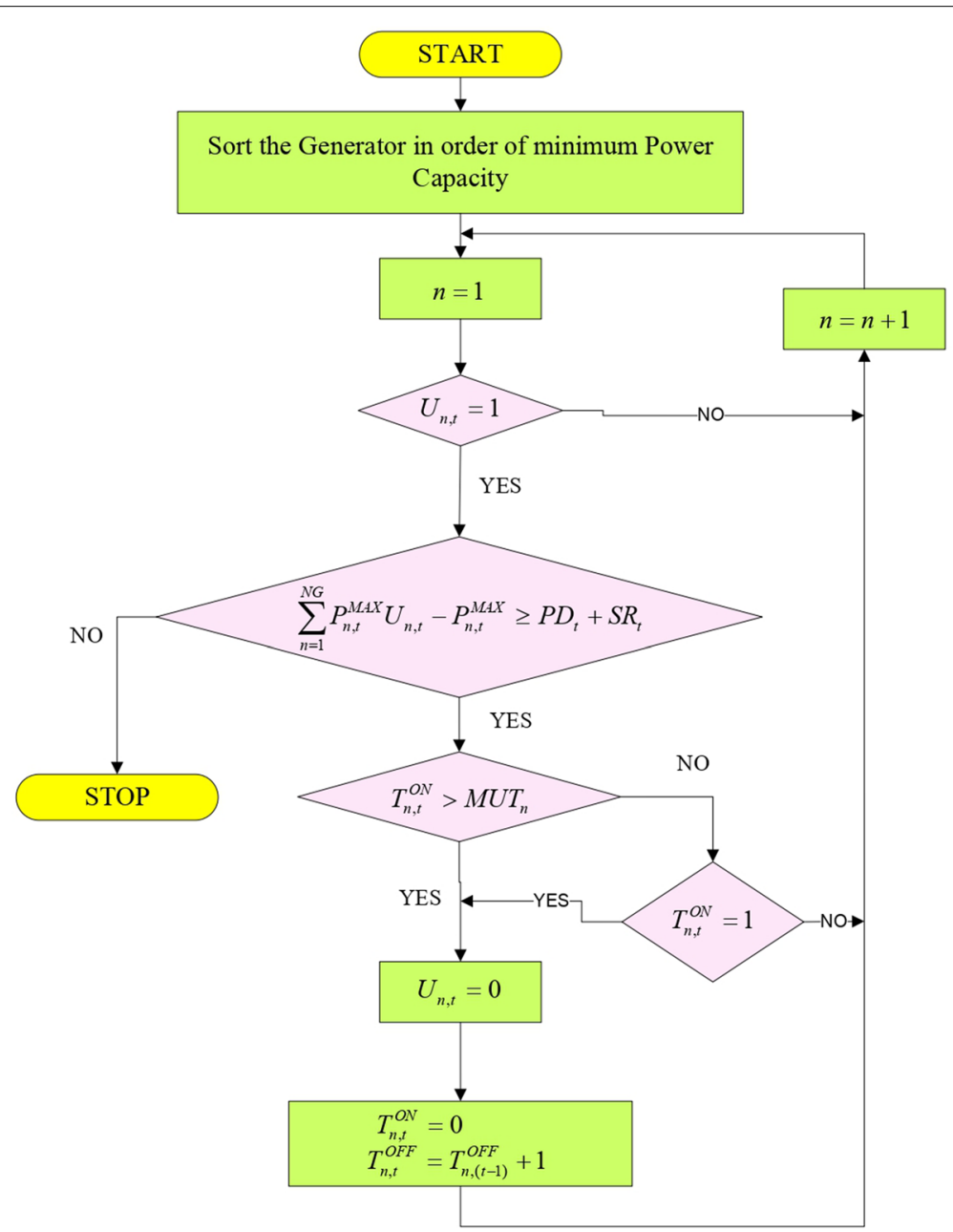

Fig. 10 Flowchart for the decommitment for excessive power generating units 

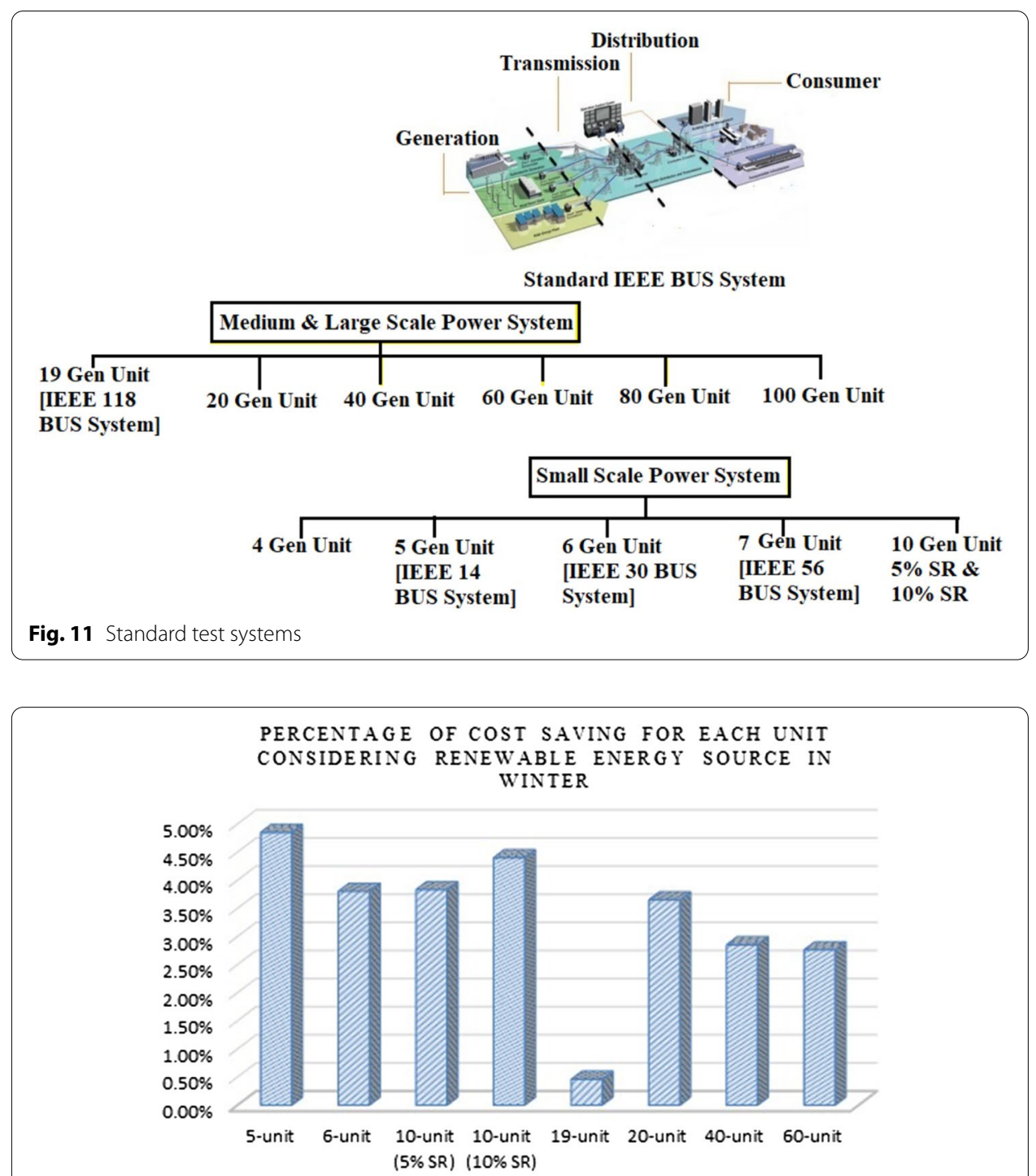

Fig. 12 Percentage of cost saving for each unit considering renewable energy source in winter using hHHO-SCA optimization technique

solar energy in summer and winter are shown in Table 2, 3, 4, 5, 6, 7, 8, 9, 10, 11, 12, 13, 14, 15, 16, 17, 18, 19, 20 21, 22, 23, 24 and 25 (Figs. 11, 12 and 13).

5-Generating Unit Test Systems: The first test system contains IEEE-14 bus systems which have 24 -hour power demand with $10 \%$ spinning reserve. The hHHOSCA technique is considered for 100 iterations. Tables 2 and 12 show that optimal scheduling for this test system considering summer and winter, respectively, using the hHHO-SCA algorithm is 8226.6 /hour and 8572.9 \$/hour. Without considering the renewable energy sources, the total generation cost is $9010.1 \$ /$ hour. 
PERCENTAGE OF COST SAVING FOR EACH UNIT

CONSIDERING RENEWABLE ENERGY SOURCE IN SUMMER

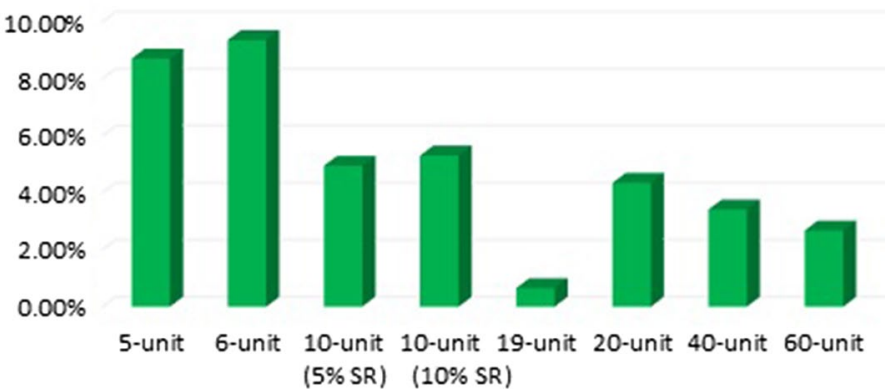

Fig. 13 Percentage of cost saving for each unit considering renewable energy source in winter using hHHO-SCA optimization technique

6-Generating Unit Test System: The second test system contains 6-generating units for IEEE-30 bus test systems with 24-hour electrical load demand including

Table 2 Power scheduling for 5 generating system considering renewable energy in summer

\begin{tabular}{|c|c|c|c|c|c|}
\hline \multirow[t]{2}{*}{ Hour } & \multicolumn{5}{|c|}{ Generation schedule of committed units } \\
\hline & GU1 & GU2 & GU3 & GU4 & GU5 \\
\hline 1 & 148 & 0 & 0 & 0 & 0 \\
\hline 2 & 173 & 0 & 0 & 0 & 0 \\
\hline 3 & 220 & 0 & 0 & 0 & 0 \\
\hline 4 & 104 & 140 & 0 & 0 & 0 \\
\hline 5 & 119 & 140 & 0 & 0 & 0 \\
\hline 6 & 108 & 140 & 0 & 0 & 0 \\
\hline 7 & 227 & 0 & 0 & 0 & 0 \\
\hline 8 & 0 & 97.45 & 100 & 0 & 0 \\
\hline 9 & 0 & 60.33 & 100 & 0 & 0 \\
\hline 10 & 0 & 106.66 & 0 & 0 & 0 \\
\hline 11 & 62.83 & 0 & 0 & 0 & 0 \\
\hline 12 & 83.94 & 0 & 0 & 0 & 0 \\
\hline 13 & 105.14 & 0 & 0 & 0 & 0 \\
\hline 14 & 113.53 & 0 & 0 & 0 & 0 \\
\hline 15 & 150.41 & 0 & 0 & 0 & 0 \\
\hline 16 & 176.14 & 0 & 0 & 0 & 0 \\
\hline 17 & 206.16 & 0 & 0 & 0 & 0 \\
\hline 18 & 207.4 & 0 & 0 & 0 & 0 \\
\hline 19 & 210.41 & 0 & 0 & 0 & 0 \\
\hline 20 & 203.49 & 0 & 0 & 0 & 0 \\
\hline 21 & 175.84 & 0 & 0 & 0 & 0 \\
\hline 22 & 157 & 0 & 0 & 0 & 0 \\
\hline 23 & 138 & 0 & 0 & 0 & 0 \\
\hline 24 & 103 & 0 & 0 & 0 & 0 \\
\hline
\end{tabular}


Table 3 Power scheduling for 6-generating unit system considering renewable energy in summer

\begin{tabular}{|c|c|c|c|c|c|c|}
\hline \multirow[t]{2}{*}{ Hour } & \multicolumn{6}{|c|}{ Generation schedule of committed units } \\
\hline & GU1 & GU2 & GU3 & GU4 & GU5 & GU6 \\
\hline 1 & 166 & 0 & 0 & 0 & 0 & 0 \\
\hline 2 & 154.35294 & 41.647059 & 0 & 0 & 0 & 0 \\
\hline 3 & 181.52941 & 47.470588 & 0 & 0 & 0 & 0 \\
\hline 4 & 196.52466 & 50.683857 & 19.79148 & 0 & 0 & 0 \\
\hline 5 & 200 & 60.78125 & 22.61875 & 0 & 0 & 0 \\
\hline 6 & 200 & 51.875 & 20.125 & 0 & 0 & 0 \\
\hline 7 & 195.52941 & 50.470589 & 0 & 0 & 0 & 0 \\
\hline 8 & 164.60588 & 43.844118 & 0 & 0 & 0 & 0 \\
\hline 9 & 176.33 & 0 & 0 & 0 & 0 & 0 \\
\hline 10 & 133.66 & 0 & 0 & 0 & 0 & 0 \\
\hline 11 & 109.83 & 0 & 0 & 0 & 0 & 0 \\
\hline 12 & 113.94 & 0 & 0 & 0 & 0 & 0 \\
\hline 13 & 118.14 & 0 & 0 & 0 & 0 & 0 \\
\hline 14 & 130.53 & 0 & 0 & 0 & 0 & 0 \\
\hline 15 & 163.41 & 0 & 0 & 0 & 0 & 0 \\
\hline 16 & 143.76235 & 39.377647 & 0 & 0 & 0 & 0 \\
\hline 17 & 164.36706 & 43.792941 & 0 & 0 & 0 & 0 \\
\hline 18 & 163.74118 & 43.658824 & 0 & 0 & 0 & 0 \\
\hline 19 & 171.16118 & 45.248824 & 0 & 0 & 0 & 0 \\
\hline 20 & 172.87412 & 45.615882 & 0 & 0 & 0 & 0 \\
\hline 21 & 160.80941 & 43.030588 & 0 & 0 & 0 & 0 \\
\hline 22 & 142.82353 & 39.176471 & 0 & 0 & 0 & 0 \\
\hline 23 & 161 & 0 & 0 & 0 & 0 & 0 \\
\hline 24 & 131 & 0 & 0 & 0 & 0 & 0 \\
\hline
\end{tabular}

$10 \%$ SR [145]. The hHHO-SCA algorithm is assessed for 100 iterations. Tables 3 and 13 show that optimal scheduling for this test system considering summer and winter, respectively, using the hHHO-SCA algorithm is 12229 \$/hour and 12977 \$/ hour. Without considering the renewable energy sources, the total generation cost is 13489.93957 \$/hour.

10-Generating Unit Test System: The third system contains 10 units power generating units. This system has been verified for 24-hour electric power demand outline at various spinning reserve capability. Case- 1 consists of spinning reserve capability of $5 \%$, and case- 2 contains spinning reserve capability of $10 \%$.

Case-1: 10-Generating Unit Test System (SR=5\%): The system consists of 10 power generating units with 24-hour electrical load demand including 5\% SR [146]. The 
Table 4 Power scheduling for 10-generating unit system (5\% SR) considering renewable energy in summer

\begin{tabular}{|c|c|c|c|c|c|c|c|c|c|c|}
\hline \multirow[t]{2}{*}{ Hour } & \multicolumn{10}{|c|}{ Generation schedule of committed units } \\
\hline & GU1 & GU2 & GU3 & GU4 & GU5 & GU6 & GU7 & GU8 & GU9 & GU10 \\
\hline h1 & 400 & 150 & 150 & 0 & 0 & 0 & 0 & 0 & 0 & 0 \\
\hline h2 & 450 & 150 & 150 & 0 & 0 & 0 & 0 & 0 & 0 & 0 \\
\hline h3 & 455 & 197.5 & 197.5 & 0 & 0 & 0 & 0 & 0 & 0 & 0 \\
\hline h4 & 455 & 247.5 & 247.5 & 0 & 0 & 0 & 0 & 0 & 0 & 0 \\
\hline h5 & 455 & 272.5 & 272.5 & 0 & 0 & 0 & 0 & 0 & 0 & 0 \\
\hline h6 & 455 & 322.5 & 322.5 & 0 & 0 & 0 & 0 & 0 & 0 & 0 \\
\hline h7 & 455 & 347.5 & 347.5 & 0 & 0 & 0 & 0 & 0 & 0 & 0 \\
\hline h8 & 455 & 370.225 & 370.225 & 0 & 0 & 0 & 0 & 0 & 0 & 0 \\
\hline h9 & 455 & 414.665 & 414.665 & 0 & 0 & 0 & 0 & 0 & 0 & 0 \\
\hline h10 & 455 & 446.33 & 446.33 & 0 & 25 & 0 & 0 & 0 & 0 & 0 \\
\hline h11 & 455 & 455 & 455 & 0 & 47.83 & 0 & 0 & 0 & 0 & 0 \\
\hline h12 & 455 & 455 & 455 & 0 & 88.94 & 0 & 0 & 0 & 0 & 0 \\
\hline h13 & 455 & 434.07 & 434.07 & 0 & 25 & 0 & 0 & 0 & 0 & 0 \\
\hline h14 & 455 & 382.765 & 382.765 & 0 & 25 & 0 & 0 & 0 & 0 & 0 \\
\hline h15 & 455 & 337.705 & 337.705 & 0 & 25 & 0 & 0 & 0 & 0 & 0 \\
\hline h16 & 455 & 260.57 & 260.57 & 0 & 25 & 0 & 0 & 0 & 0 & 0 \\
\hline h17 & 455 & 241.08 & 241.08 & 0 & 25 & 0 & 0 & 0 & 0 & 0 \\
\hline h18 & 455 & 293.2 & 293.2 & 0 & 25 & 0 & 0 & 0 & 0 & 0 \\
\hline h19 & 455 & 350.205 & 350.205 & 0 & 25 & 0 & 0 & 0 & 0 & 0 \\
\hline h20 & 455 & 455 & 455 & 0 & 28.49 & 0 & 0 & 0 & 0 & 0 \\
\hline h21 & 455 & 422.42 & 422.42 & 0 & 0 & 0 & 0 & 0 & 0 & 0 \\
\hline h22 & 455 & 322.5 & 322.5 & 0 & 0 & 0 & 0 & 0 & 0 & 0 \\
\hline h23 & 455 & 435 & 0 & 0 & 0 & 0 & 0 & 0 & 10 & 0 \\
\hline h24 & 455 & 345 & 0 & 0 & 0 & 0 & 0 & 0 & 0 & 0 \\
\hline
\end{tabular}

hHHO-SCA technique is evaluated for 100 iterations. Tables 4 and 14 show that optimal scheduling for this test system considering summer and winter, respectively, using the hHHO-SCA algorithm is 529980 \$/hour and 536200 \$/hour. Without considering the renewable energy sources, the total generation cost is $557533.12 \$ /$ hour.

Case-2: 10-Generating Unit System (SR=10\%): The system consists of 10 power generating units with 24-hour electrical load demand including 10\% SR [146]. The hHHO-SCA technique is evaluated for 100 iterations. Tables 5 and 15 show that optimal scheduling for this test system considering summer and winter, respectively, using the hHHO-SCA algorithm is 534050 \$/hour and 539110 \$/hour. Without considering the renewable energy sources, the total generation cost is $563937.6875 \$$ /hour. 
Table 5 Power scheduling for 10 -generating unit system (10\% SR) considering renewable energy in summer

\begin{tabular}{|c|c|c|c|c|c|c|c|c|c|c|}
\hline \multirow[t]{2}{*}{ Hour } & \multicolumn{10}{|c|}{ Generation schedule of committed units } \\
\hline & GU1 & GU2 & GU3 & GU4 & GU5 & GU6 & GU7 & GU8 & GU9 & GU10 \\
\hline h1 & 400 & 150 & 150 & 0 & 0 & 0 & 0 & 0 & 0 & 0 \\
\hline h2 & 450 & 150 & 150 & 0 & 0 & 0 & 0 & 0 & 0 & 0 \\
\hline h3 & 455 & 197.5 & 197.5 & 0 & 0 & 0 & 0 & 0 & 0 & 0 \\
\hline h4 & 455 & 247.5 & 247.5 & 0 & 0 & 0 & 0 & 0 & 0 & 0 \\
\hline h5 & 455 & 272.5 & 272.5 & 0 & 0 & 0 & 0 & 0 & 0 & 0 \\
\hline h6 & 455 & 322.5 & 322.5 & 0 & 0 & 0 & 0 & 0 & 0 & 0 \\
\hline h7 & 455 & 347.5 & 347.5 & 0 & 0 & 0 & 0 & 0 & 0 & 0 \\
\hline h8 & 455 & 370.225 & 370.225 & 0 & 0 & 0 & 0 & 0 & 0 & 0 \\
\hline h9 & 455 & 402.165 & 402.165 & 0 & 25 & 0 & 0 & 0 & 0 & 0 \\
\hline h10 & 455 & 446.33 & 446.33 & 0 & 25 & 0 & 0 & 0 & 0 & 0 \\
\hline h11 & 455 & 455 & 455 & 0 & 27.93 & 20 & 0 & 0 & 0 & 0 \\
\hline h12 & 455 & 455 & 455 & 0 & 68.94 & 20 & 0 & 0 & 0 & 0 \\
\hline h13 & 455 & 424.07 & 424.07 & 0 & 25 & 20 & 0 & 0 & 0 & 0 \\
\hline h14 & 455 & 382.765 & 382.765 & 0 & 25 & 0 & 0 & 0 & 0 & 0 \\
\hline h15 & 455 & 350.205 & 350.205 & 0 & 0 & 0 & 0 & 0 & 0 & 0 \\
\hline h16 & 455 & 273.07 & 273.07 & 0 & 0 & 0 & 0 & 0 & 0 & 0 \\
\hline h17 & 455 & 253.58 & 253.58 & 0 & 0 & 0 & 0 & 0 & 0 & 0 \\
\hline h18 & 455 & 305.7 & 305.7 & 0 & 0 & 0 & 0 & 0 & 0 & 0 \\
\hline h19 & 455 & 362.705 & 362.705 & 0 & 0 & 0 & 0 & 0 & 0 & 0 \\
\hline h20 & 455 & 394.245 & 394.245 & 130 & 0 & 20 & 0 & 0 & 0 & 0 \\
\hline h21 & 455 & 347.42 & 347.42 & 130 & 0 & 20 & 0 & 0 & 0 & 0 \\
\hline h22 & 455 & 247.5 & 247.5 & 130 & 0 & 20 & 0 & 0 & 0 & 0 \\
\hline h23 & 455 & 315 & 0 & 130 & 0 & 0 & 0 & 0 & 0 & 0 \\
\hline h24 & 455 & 215 & 0 & 130 & 0 & 0 & 0 & 0 & 0 & 0 \\
\hline
\end{tabular}

Medium-Scale and Large-Scale Electrical Power System (19-, 20-, 40-, 60-, 80and 100-Unit System): The data for 20 and 40 generating unit test systems and the 10-unit system had been doubled and quadrupled, and electric power demand is multiplied by two and four times correspondingly [145].

19-Generating Unit System: The fourth system contains 19 power generating units of IEEE-118 bus test system with a 24-hour electricity load demand including 10\% SR [145]. The hHHO-SCA technique is evaluated for 100 iterations. Tables 6 and 16 show that optimal scheduling for this test system considering summer and winter, respectively, using the hHHO-SCA algorithm is $207180 \$$ /hour and 207560 /hour. Without considering the renewable energy sources, the total generation cost is $208510 \$ /$ hour.

20-Generating Unit System: The fifth system contains 20-power generating units with 24-hour electricity demand including 10\% SR [145]. The hHHO-SCA algorithm is assessed for 100 iterations. Tables 7 and 17 show that optimal scheduling for this 


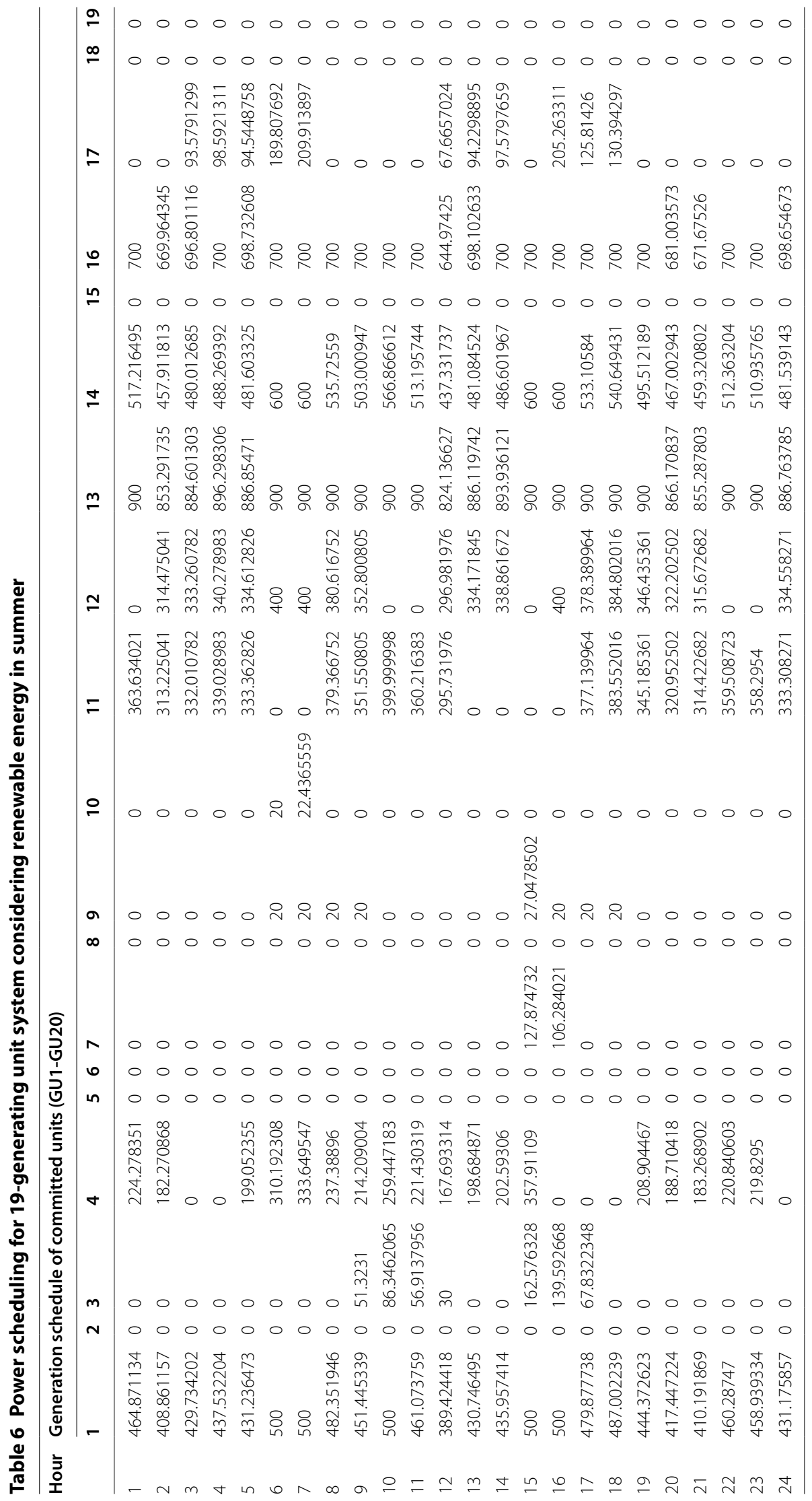




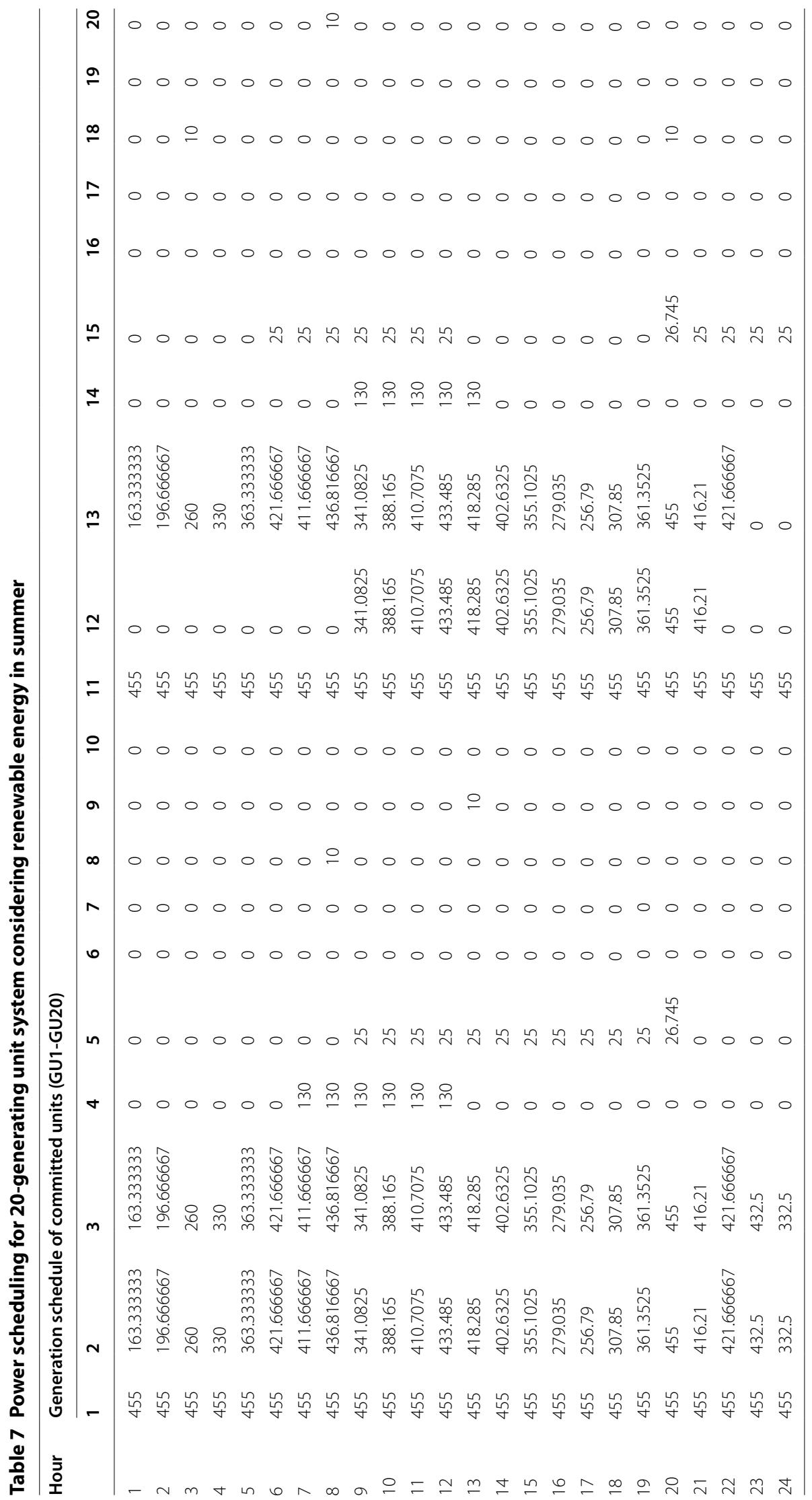




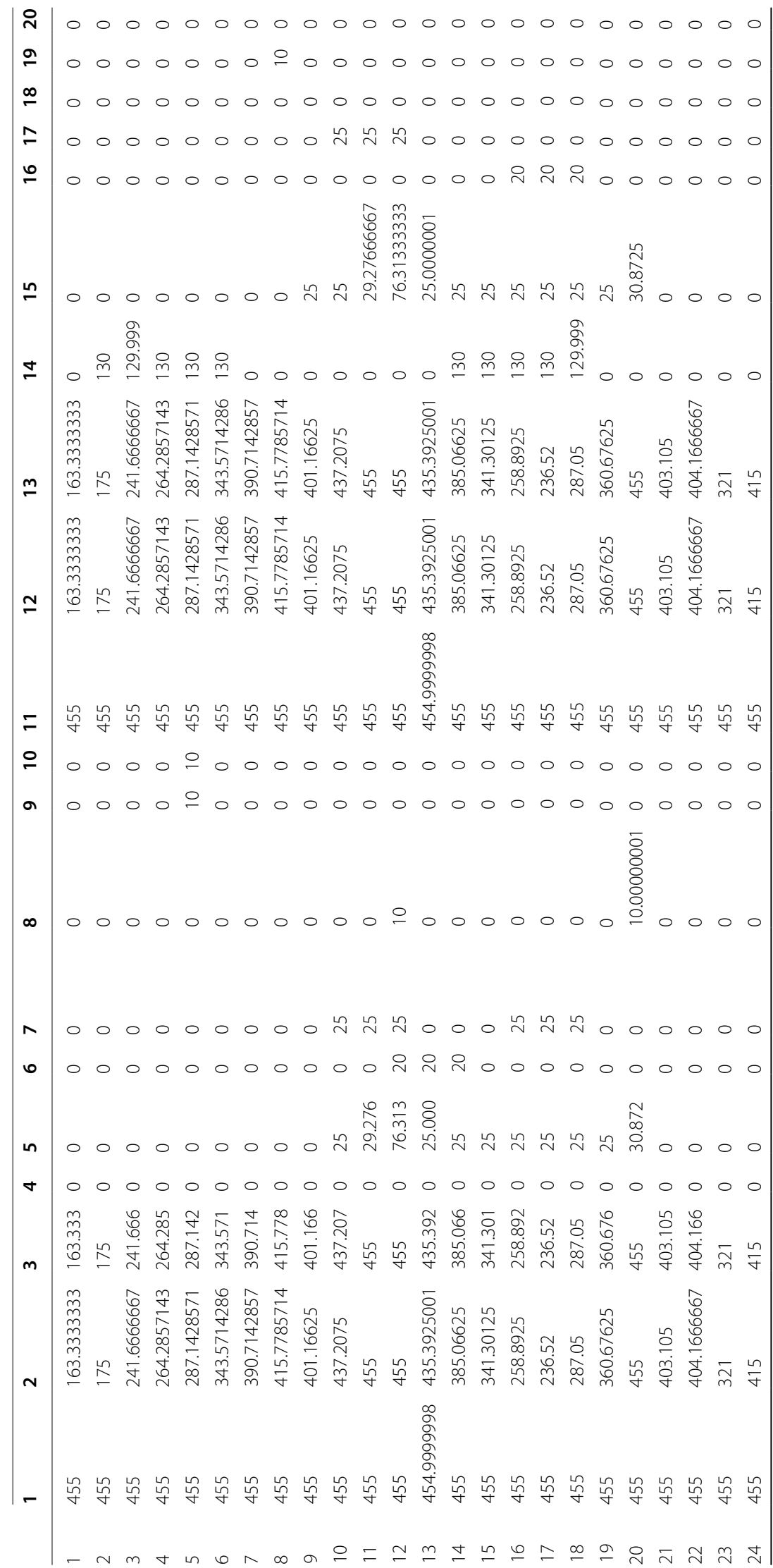




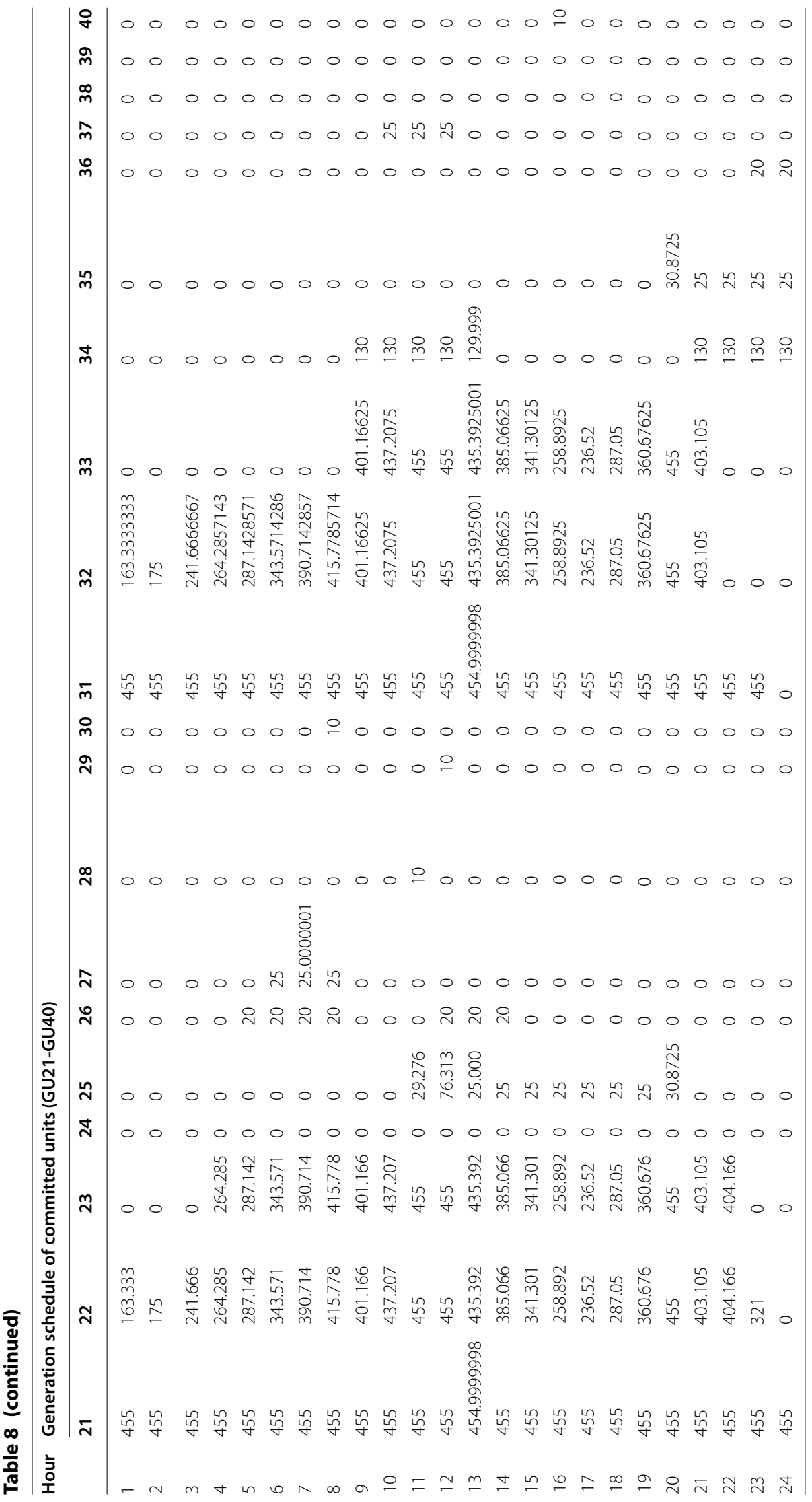




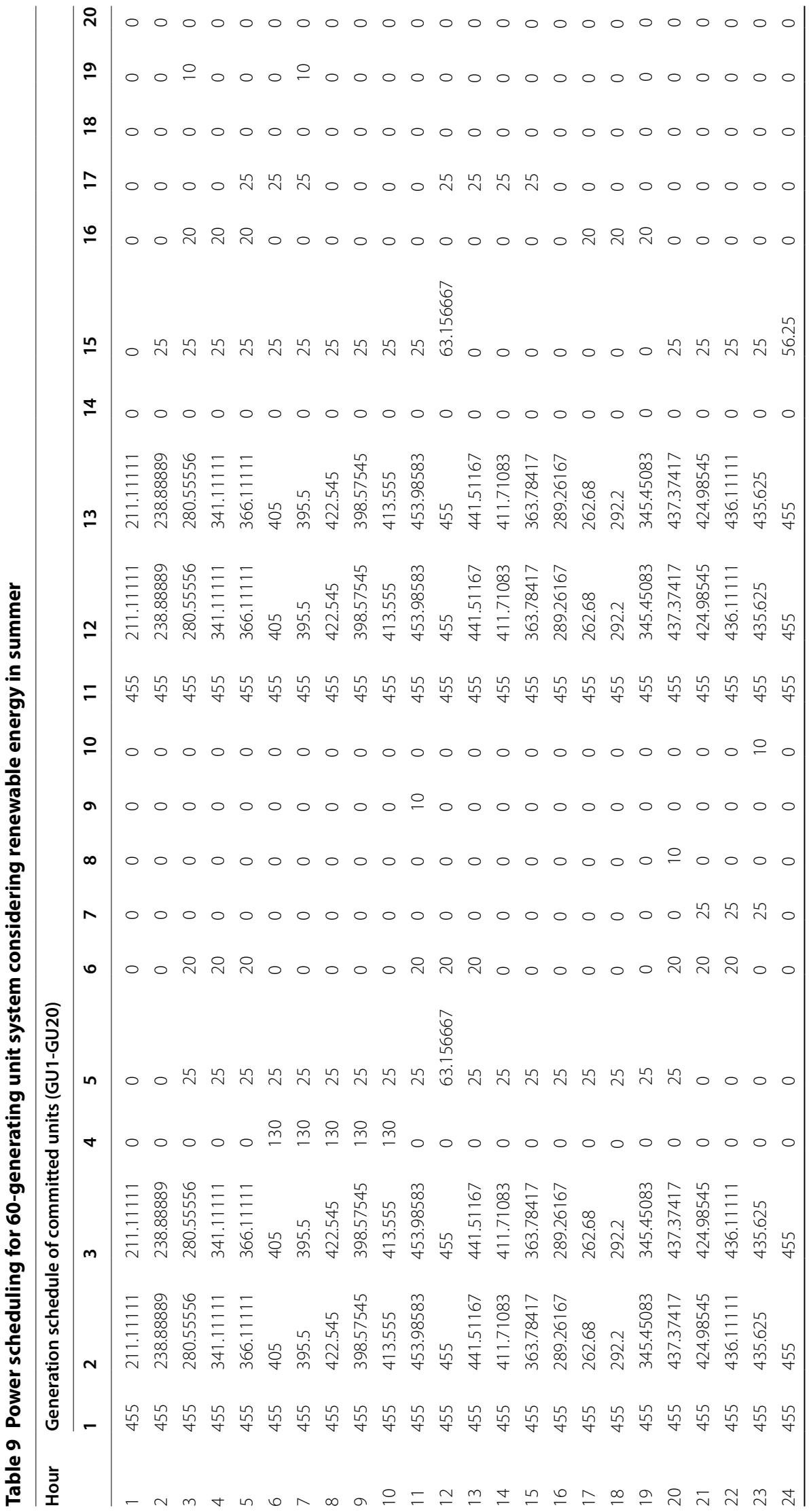




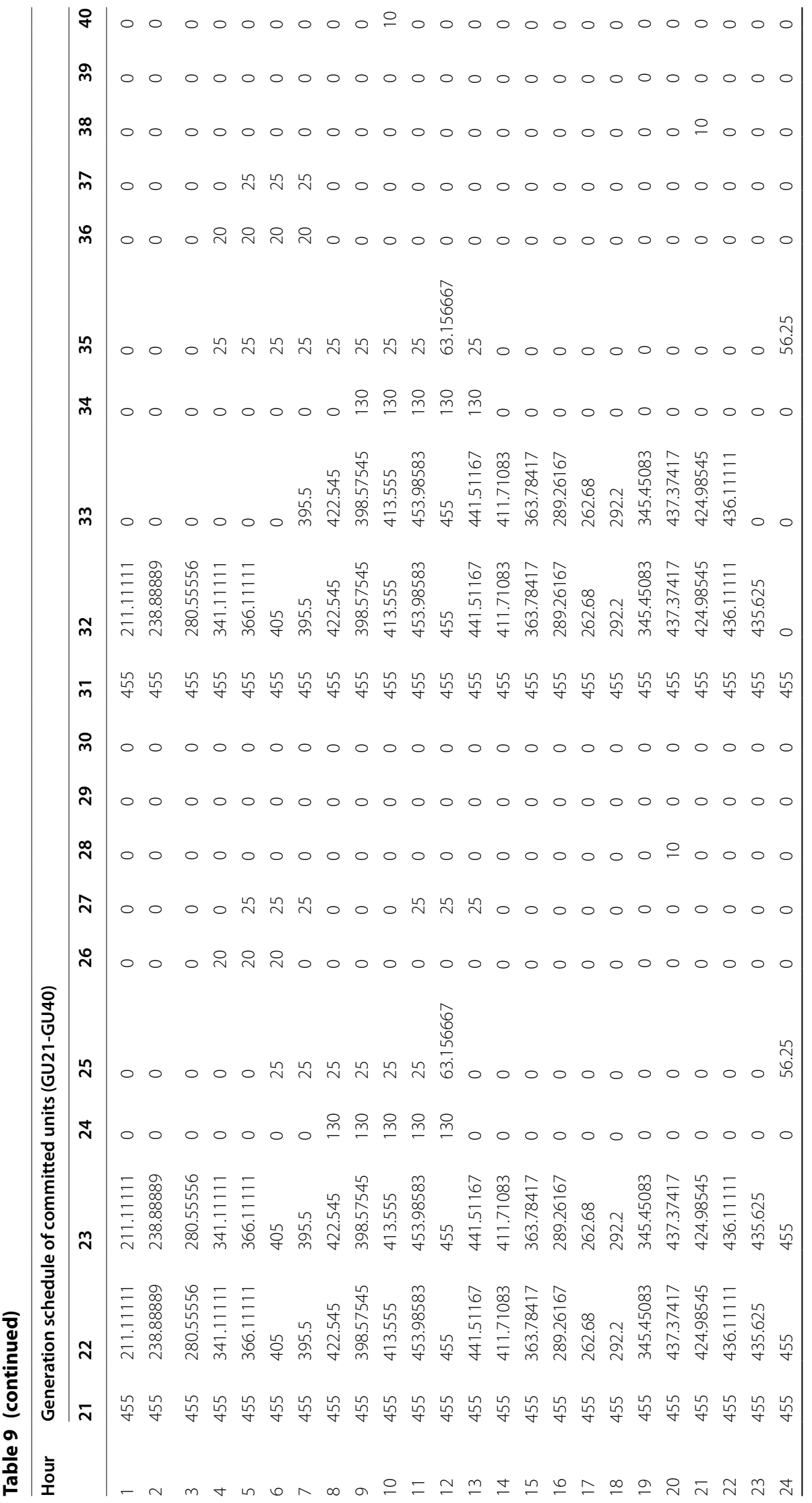




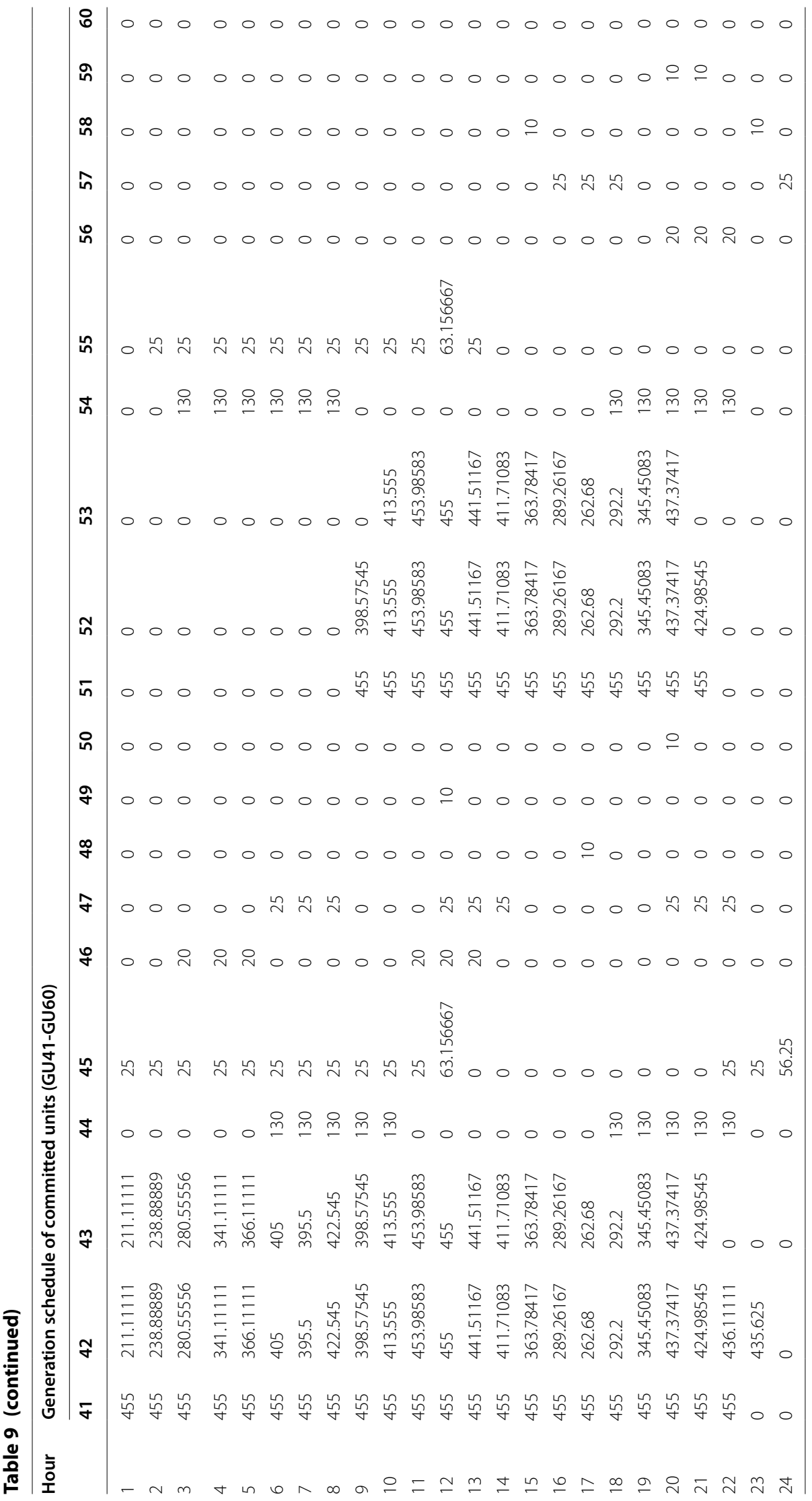




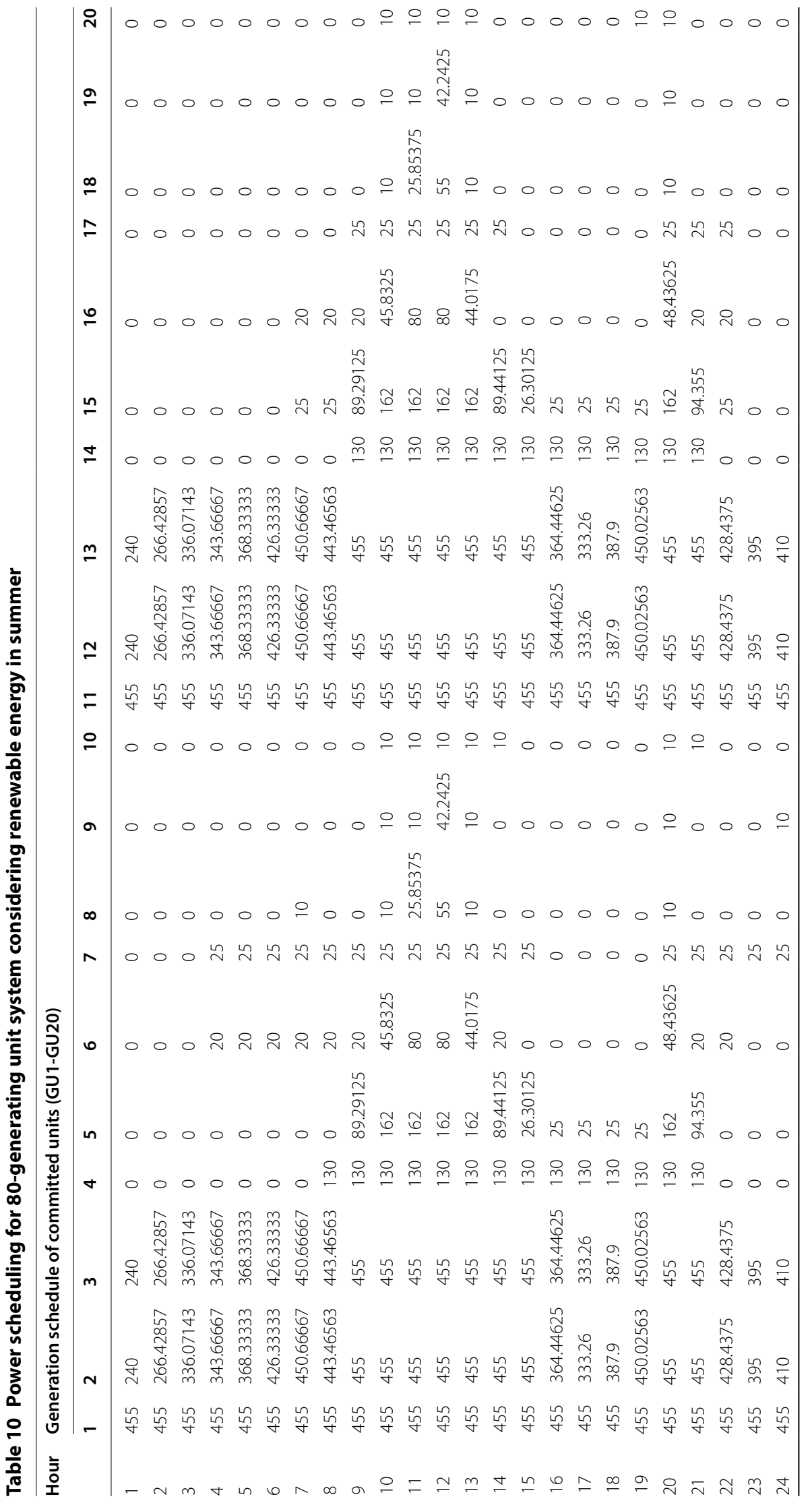




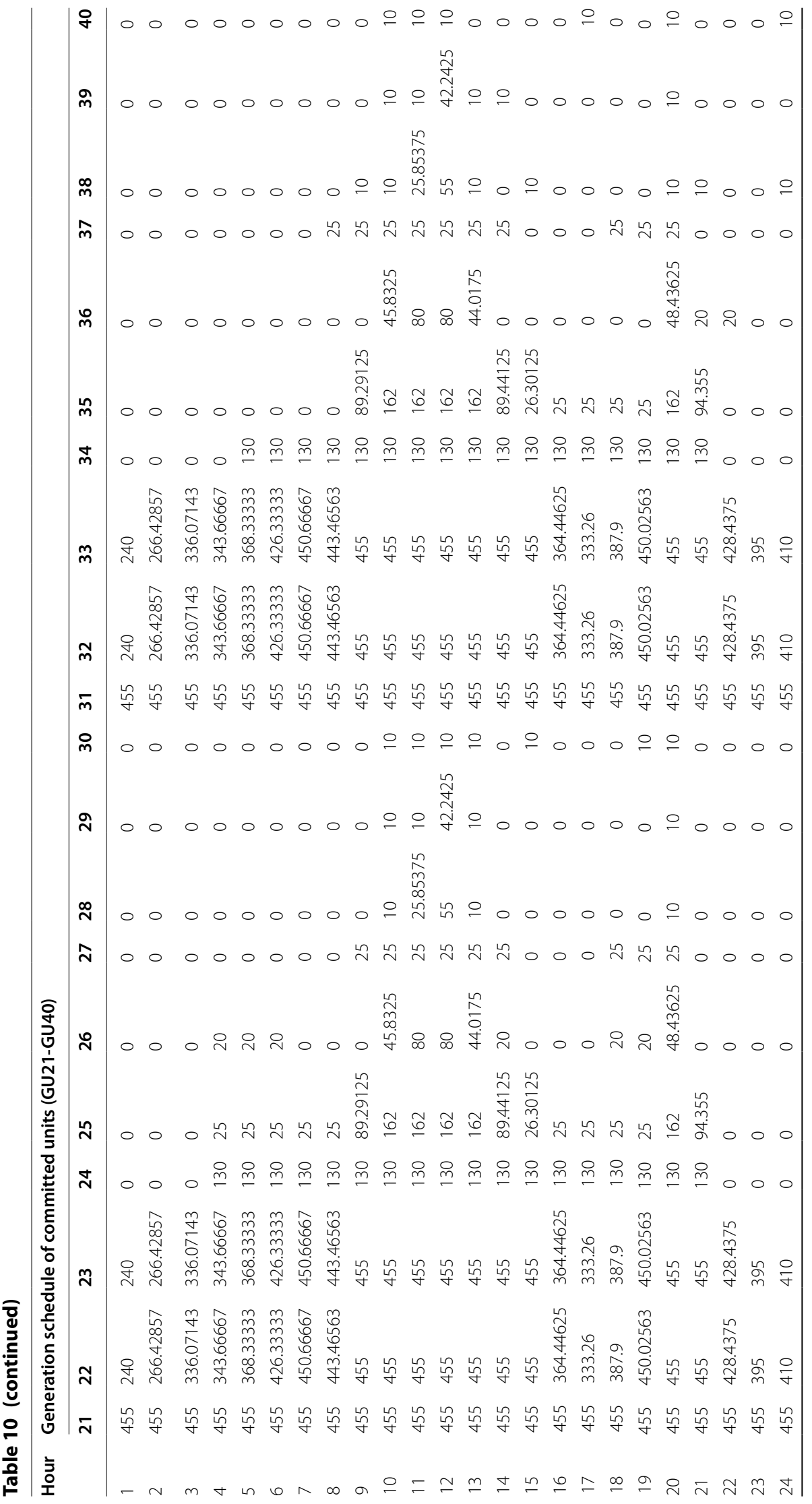









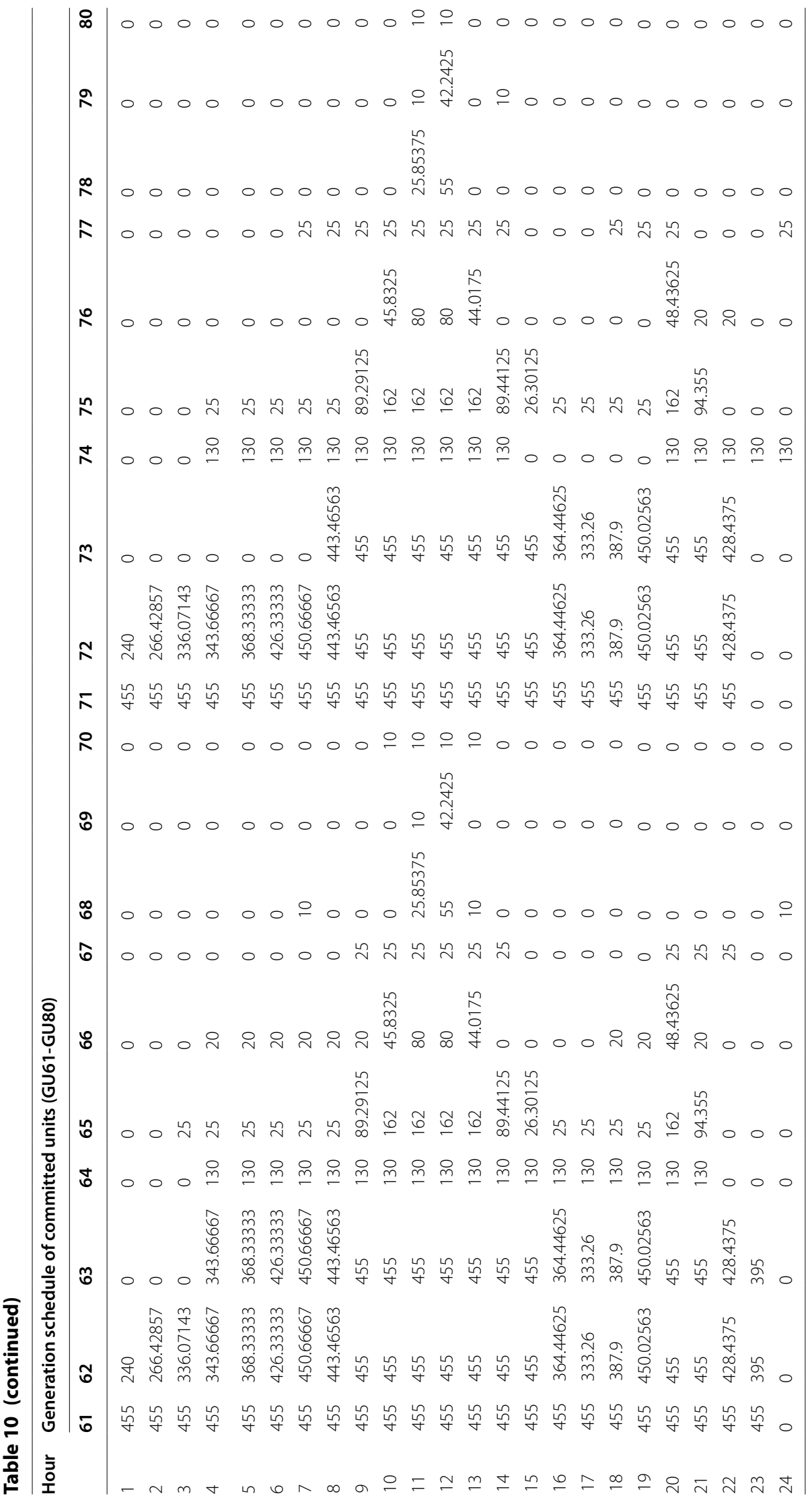




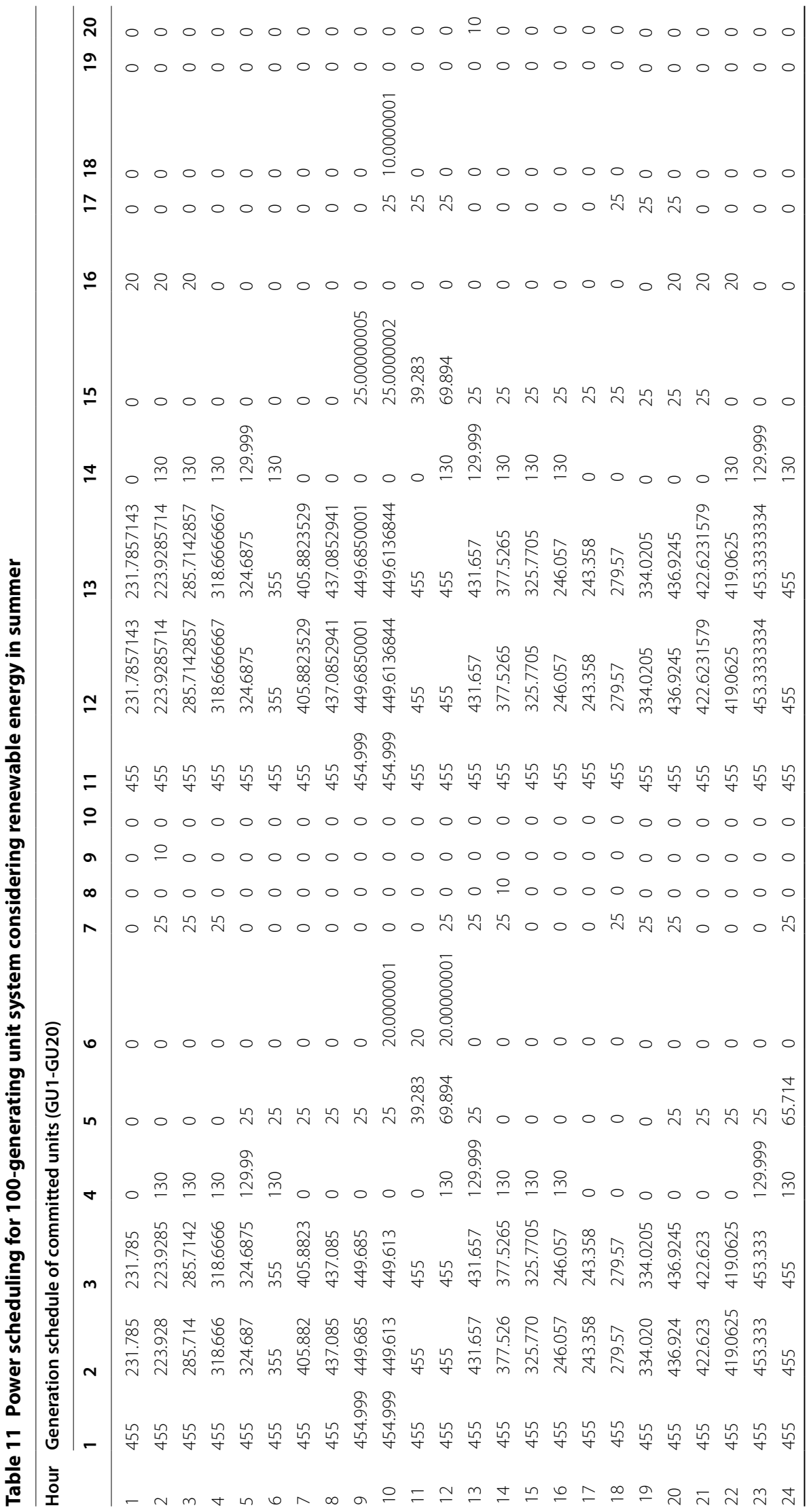









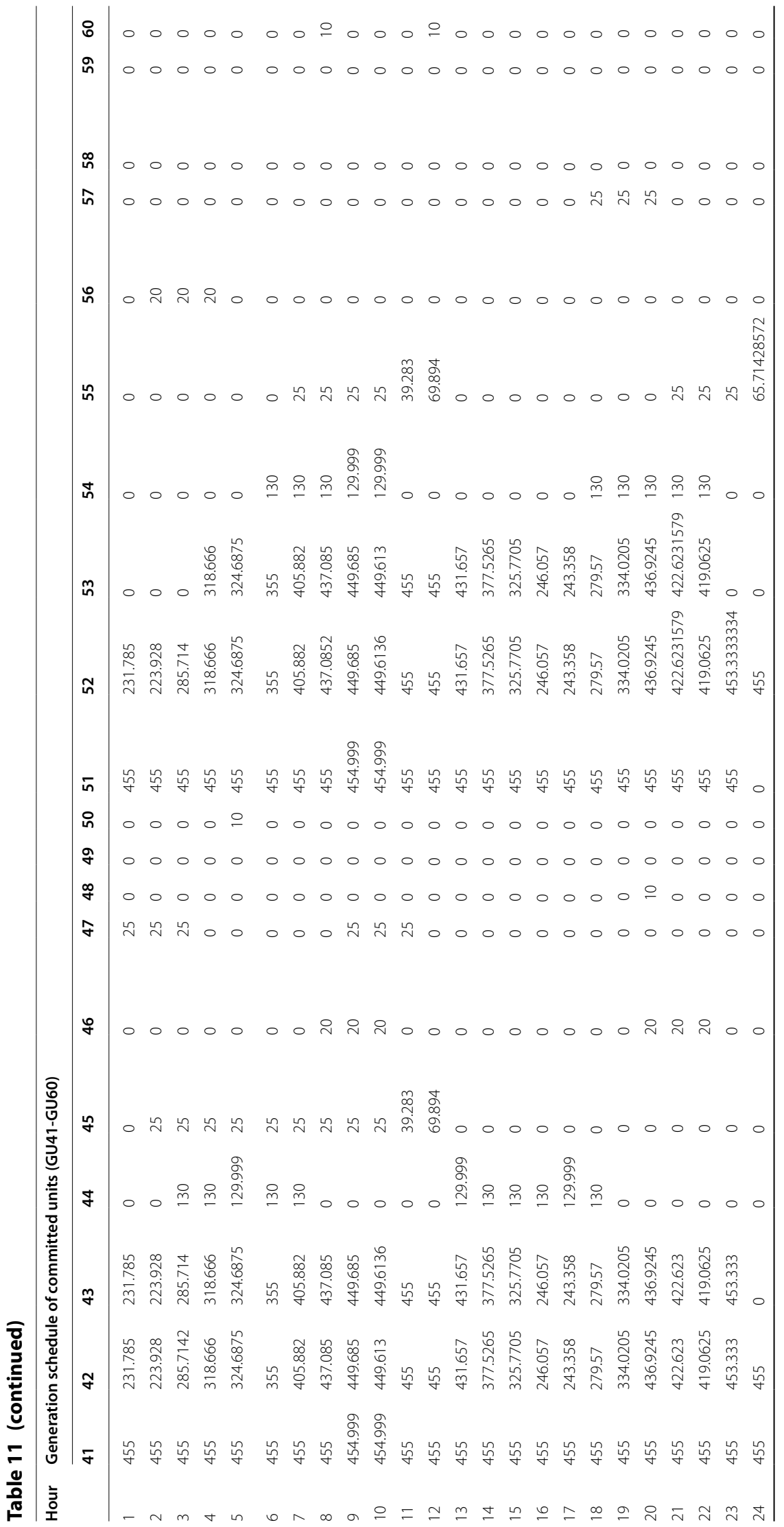




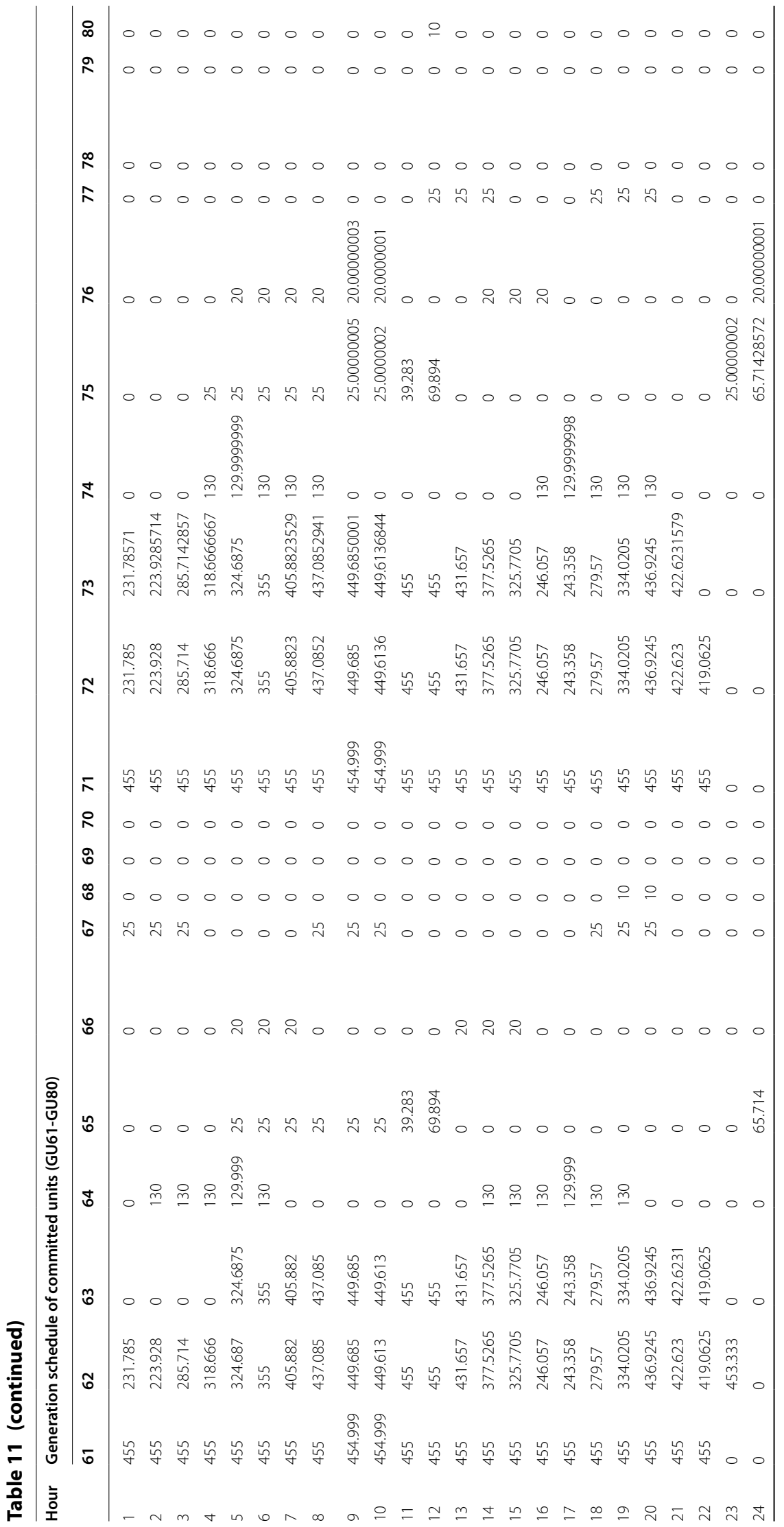







Table 12 Power scheduling for 5-generating unit system considering renewable energy in winter

\begin{tabular}{|c|c|c|c|c|c|}
\hline \multirow[t]{2}{*}{ Hour } & \multicolumn{5}{|c|}{ Generation schedule of committed units } \\
\hline & GU1 & GU2 & GU3 & GU4 & GU5 \\
\hline h1 & 0 & 48 & 100 & 0 & 0 \\
\hline h2 & 0 & 73 & 100 & 0 & 0 \\
\hline h3 & 220 & 0 & 0 & 0 & 0 \\
\hline h4 & 144 & 0 & 100 & 0 & 0 \\
\hline h5 & 119 & 140 & 0 & 0 & 0 \\
\hline h6 & 108 & 140 & 0 & 0 & 0 \\
\hline h7 & 227 & 0 & 0 & 0 & 0 \\
\hline h8 & 202 & 0 & 0 & 0 & 0 \\
\hline h9 & 175.4271 & 0 & 0 & 0 & 0 \\
\hline h10 & 130.44 & 0 & 0 & 0 & 0 \\
\hline h11 & 93.4 & 0 & 0 & 0 & 0 \\
\hline h12 & 111.96 & 0 & 0 & 0 & 0 \\
\hline h13 & 135.01 & 0 & 0 & 0 & 0 \\
\hline h14 & 151.48 & 0 & 0 & 0 & 0 \\
\hline h15 & 162.88 & 0 & 0 & 0 & 0 \\
\hline h16 & 196.4 & 0 & 0 & 0 & 0 \\
\hline h17 & 220.91 & 0 & 0 & 0 & 0 \\
\hline h18 & 222.68 & 0 & 0 & 0 & 0 \\
\hline h19 & 222.02 & 0 & 0 & 0 & 0 \\
\hline h20 & 209.82 & 0 & 0 & 0 & 0 \\
\hline h21 & 176 & 0 & 0 & 0 & 0 \\
\hline h22 & 157 & 0 & 0 & 0 & 0 \\
\hline h23 & 138 & 0 & 0 & 0 & 0 \\
\hline h24 & 103 & 0 & 0 & 0 & 0 \\
\hline
\end{tabular}

test system considering summer and winter, respectively, using the hHHO-SCA algorithm is $1076400 \$$ /hour and $1084100 \$$ /hour. Without considering the renewable energy sources, the total generation cost is 1125200 \$/hour.

40-Generating Unit System: The sixth system contains 40-power generating units having a 24-hour electricity demand including 10\% SR [145]. The hHHO-SCA technique is evaluated for 100 iterations. Tables 8 and 18 show that optimal scheduling for this test system considering summer and winter, respectively, using the hHHO-SCA algorithm is 2176900 /hour and 2189400 \$/hour. Without considering the renewable energy sources, the total generation cost is $2253700 \$$ /hour.

60-Generating Unit System: The seventh system contains 60-power generating units with 24-hour electricity demand including 10\% SR [145]. The hHHO-SCA technique is evaluated for 100 iterations. Tables 9 and 19 show that optimal scheduling for this test system considering summer and winter, respectively, using the hHHO-SCA algorithm is 8226.6 /hour and 8572.9 \$/hour. Without considering the renewable energy sources, the total generation cost is $9010.1 \$$ /hour. 
Table 13 Power scheduling for 6-generating unit system considering renewable energy in winter

\begin{tabular}{|c|c|c|c|c|c|c|}
\hline \multirow[t]{2}{*}{ Hour } & \multicolumn{6}{|c|}{ Generation schedule of committed units } \\
\hline & GU1 & GU2 & GU3 & GU4 & GU5 & GU6 \\
\hline h1 & 166 & 0 & 0 & 0 & 0 & 0 \\
\hline h2 & 154.35294 & 41.647059 & 0 & 0 & 0 & 0 \\
\hline h3 & 181.52941 & 47.470588 & 0 & 0 & 0 & 0 \\
\hline h4 & 196.52466 & 50.683857 & 19.79148 & 0 & 0 & 0 \\
\hline h5 & 200 & 60.78125 & 22.61875 & 0 & 0 & 0 \\
\hline h6 & 200 & 51.875 & 20.125 & 0 & 0 & 0 \\
\hline h7 & 195.52941 & 50.470589 & 0 & 0 & 0 & 0 \\
\hline h8 & 168.35294 & 44.647059 & 0 & 0 & 0 & 0 \\
\hline h9 & 150.58702 & 40.840077 & 0 & 0 & 0 & 0 \\
\hline h10 & 157.44 & 0 & 0 & 0 & 0 & 0 \\
\hline h11 & 140.4 & 0 & 0 & 0 & 0 & 0 \\
\hline h12 & 141.96 & 0 & 0 & 0 & 0 & 0 \\
\hline h13 & 148.01 & 0 & 0 & 0 & 0 & 0 \\
\hline h14 & 168.48 & 0 & 0 & 0 & 0 & 0 \\
\hline h15 & 175.88 & 0 & 0 & 0 & 0 & 0 \\
\hline h16 & 160.44706 & 42.952941 & 0 & 0 & 0 & 0 \\
\hline h17 & 176.51412 & 46.395882 & 0 & 0 & 0 & 0 \\
\hline h18 & 176.32471 & 46.355294 & 0 & 0 & 0 & 0 \\
\hline h19 & 180.72235 & 47.297647 & 0 & 0 & 0 & 0 \\
\hline h20 & 178.08706 & 46.732941 & 0 & 0 & 0 & 0 \\
\hline h21 & 160.94118 & 43.058824 & 0 & 0 & 0 & 0 \\
\hline h22 & 142.82353 & 39.176471 & 0 & 0 & 0 & 0 \\
\hline h23 & 161 & 0 & 0 & 0 & 0 & 0 \\
\hline h24 & 131 & 0 & 0 & 0 & 0 & 0 \\
\hline
\end{tabular}

80-Generating Unit System: The eighth system contains 80-power generating units with 24-hour power demand including 10\% SR [145]. The hHHO-SCA technique is evaluated for 100 iterations. Tables 10 and 20 show that optimal scheduling for this test system considering summer and winter, respectively, using the hHHO-SCA algorithm is 5578000 \$/ hour and 5591700 \$/hour.

100-Generating Unit System: The ninth system contains 100-power generating units with 24-hour power demand including 10\% SR [145]. The hHHO-SCA technique is evaluated for 100 iterations. Tables 11 and 21 show that optimal scheduling for this test system considering summer and winter, respectively, using the hHHO-SCA algorithm is 5530800 \$/hour and 552990 \$/hour (Tables 22, 23, 24, 25). 
Table 14 Power scheduling for 10 -generating unit system (5\% SR) considering renewable energy in winter

\begin{tabular}{|c|c|c|c|c|c|c|c|c|c|c|}
\hline \multirow[t]{2}{*}{ Hour } & \multicolumn{10}{|c|}{ Generation schedule of committed units } \\
\hline & GU1 & GU2 & GU3 & GU4 & GU5 & GU6 & GU7 & GU8 & GU9 & GU10 \\
\hline 1 & 400 & 150 & 150 & 0 & 0 & 0 & 0 & 0 & 0 & 0 \\
\hline 2 & 450 & 150 & 150 & 0 & 0 & 0 & 0 & 0 & 0 & 0 \\
\hline 3 & 455 & 197.5 & 197.5 & 0 & 0 & 0 & 0 & 0 & 0 & 0 \\
\hline 4 & 455 & 247.5 & 247.5 & 0 & 0 & 0 & 0 & 0 & 0 & 0 \\
\hline 5 & 455 & 272.5 & 272.5 & 0 & 0 & 0 & 0 & 0 & 0 & 0 \\
\hline 6 & 455 & 322.5 & 322.5 & 0 & 0 & 0 & 0 & 0 & 0 & 0 \\
\hline 7 & 455 & 347.5 & 347.5 & 0 & 0 & 0 & 0 & 0 & 0 & 0 \\
\hline 8 & 455 & 372.5 & 372.5 & 0 & 0 & 0 & 0 & 0 & 0 & 0 \\
\hline 9 & 455 & 422.21355 & 422.21355 & 0 & 0 & 0 & 0 & 0 & 0 & 0 \\
\hline 10 & 455 & 455 & 455 & 0 & 31.44 & 0 & 0 & 0 & 0 & 0 \\
\hline 11 & 455 & 455 & 455 & 0 & 78.4 & 0 & 0 & 0 & 0 & 0 \\
\hline 12 & 455 & 455 & 455 & 0 & 96.96 & 20 & 0 & 0 & 0 & 0 \\
\hline 13 & 455 & 439.005 & 439.005 & 0 & 25 & 20 & 0 & 0 & 0 & 0 \\
\hline 14 & 455 & 391.74 & 391.74 & 0 & 25 & 20 & 0 & 0 & 0 & 0 \\
\hline 15 & 455 & 343.94 & 343.94 & 0 & 25 & 0 & 0 & 0 & 0 & 0 \\
\hline 16 & 455 & 283.2 & 283.2 & 0 & 0 & 0 & 0 & 0 & 0 & 0 \\
\hline 17 & 455 & 260.955 & 260.955 & 0 & 0 & 0 & 0 & 0 & 0 & 0 \\
\hline 18 & 455 & 313.34 & 313.34 & 0 & 0 & 0 & 0 & 0 & 0 & 0 \\
\hline 19 & 455 & 368.51 & 368.51 & 0 & 0 & 0 & 0 & 0 & 0 & 0 \\
\hline 20 & 455 & 455 & 455 & 0 & 0 & 24.82 & 0 & 10 & 0 & 0 \\
\hline 21 & 455 & 412.5 & 412.5 & 0 & 0 & 20 & 0 & 0 & 0 & 0 \\
\hline 22 & 455 & 312.5 & 312.5 & 0 & 0 & 20 & 0 & 0 & 0 & 0 \\
\hline 23 & 455 & 222.5 & 222.5 & 0 & 0 & 0 & 0 & 0 & 0 & 0 \\
\hline 24 & 455 & 345 & 0 & 0 & 0 & 0 & 0 & 0 & 0 & 0 \\
\hline
\end{tabular}


Table 15 Power scheduling for 10 -generating unit system (10\% SR) considering renewable energy in winter

\begin{tabular}{|c|c|c|c|c|c|c|c|c|c|c|}
\hline \multirow[t]{2}{*}{ Hour } & \multicolumn{10}{|c|}{ Generation schedule of committed units } \\
\hline & GU1 & GU2 & GU3 & GU4 & GU5 & GU6 & GU7 & GU8 & GU9 & GU10 \\
\hline 1 & 400 & 150 & 150 & 0 & 0 & 0 & 0 & 0 & 0 & 0 \\
\hline 2 & 450 & 150 & 150 & 0 & 0 & 0 & 0 & 0 & 0 & 0 \\
\hline 3 & 455 & 197.5 & 197.5 & 0 & 0 & 0 & 0 & 0 & 0 & 0 \\
\hline 4 & 455 & 247.5 & 247.5 & 0 & 0 & 0 & 0 & 0 & 0 & 0 \\
\hline 5 & 455 & 272.5 & 272.5 & 0 & 0 & 0 & 0 & 0 & 0 & 0 \\
\hline 6 & 455 & 322.5 & 322.5 & 0 & 0 & 0 & 0 & 0 & 0 & 0 \\
\hline 7 & 455 & 347.5 & 347.5 & 0 & 0 & 0 & 0 & 0 & 0 & 0 \\
\hline 8 & 455 & 372.5 & 372.5 & 0 & 0 & 0 & 0 & 0 & 0 & 0 \\
\hline 9 & 455 & 357.21355 & 357.21355 & 130 & 0 & 0 & 0 & 0 & 0 & 0 \\
\hline 10 & 455 & 393.22 & 393.22 & 130 & 25 & 0 & 0 & 0 & 0 & 0 \\
\hline 11 & 455 & 416.7 & 416.7 & 130 & 25 & 0 & 0 & 0 & 0 & 0 \\
\hline 12 & 455 & 435.98 & 435.98 & 130 & 25 & 0 & 0 & 0 & 0 & 0 \\
\hline 13 & 455 & 384.005 & 384.005 & 130 & 25 & 0 & 0 & 0 & 0 & 0 \\
\hline 14 & 455 & 401.74 & 401.74 & 0 & 25 & 0 & 0 & 0 & 0 & 0 \\
\hline 15 & 455 & 343.94 & 343.94 & 0 & 25 & 0 & 0 & 0 & 0 & 0 \\
\hline 16 & 455 & 283.2 & 283.2 & 0 & 0 & 0 & 0 & 0 & 0 & 0 \\
\hline 17 & 455 & 260.955 & 260.955 & 0 & 0 & 0 & 0 & 0 & 0 & 0 \\
\hline 18 & 455 & 313.34 & 313.34 & 0 & 0 & 0 & 0 & 0 & 0 & 0 \\
\hline 19 & 455 & 368.51 & 368.51 & 0 & 0 & 0 & 0 & 0 & 0 & 0 \\
\hline 20 & 455 & 402.41 & 402.41 & 130 & 0 & 0 & 0 & 10 & 0 & 0 \\
\hline 21 & 455 & 357.5 & 357.5 & 130 & 0 & 0 & 0 & 0 & 0 & 0 \\
\hline 22 & 455 & 257.5 & 257.5 & 130 & 0 & 0 & 0 & 0 & 0 & 0 \\
\hline 23 & 455 & 315 & 0 & 130 & 0 & 0 & 0 & 0 & 0 & 0 \\
\hline 24 & 455 & 215 & 0 & 130 & 0 & 0 & 0 & 0 & 0 & 0 \\
\hline
\end{tabular}




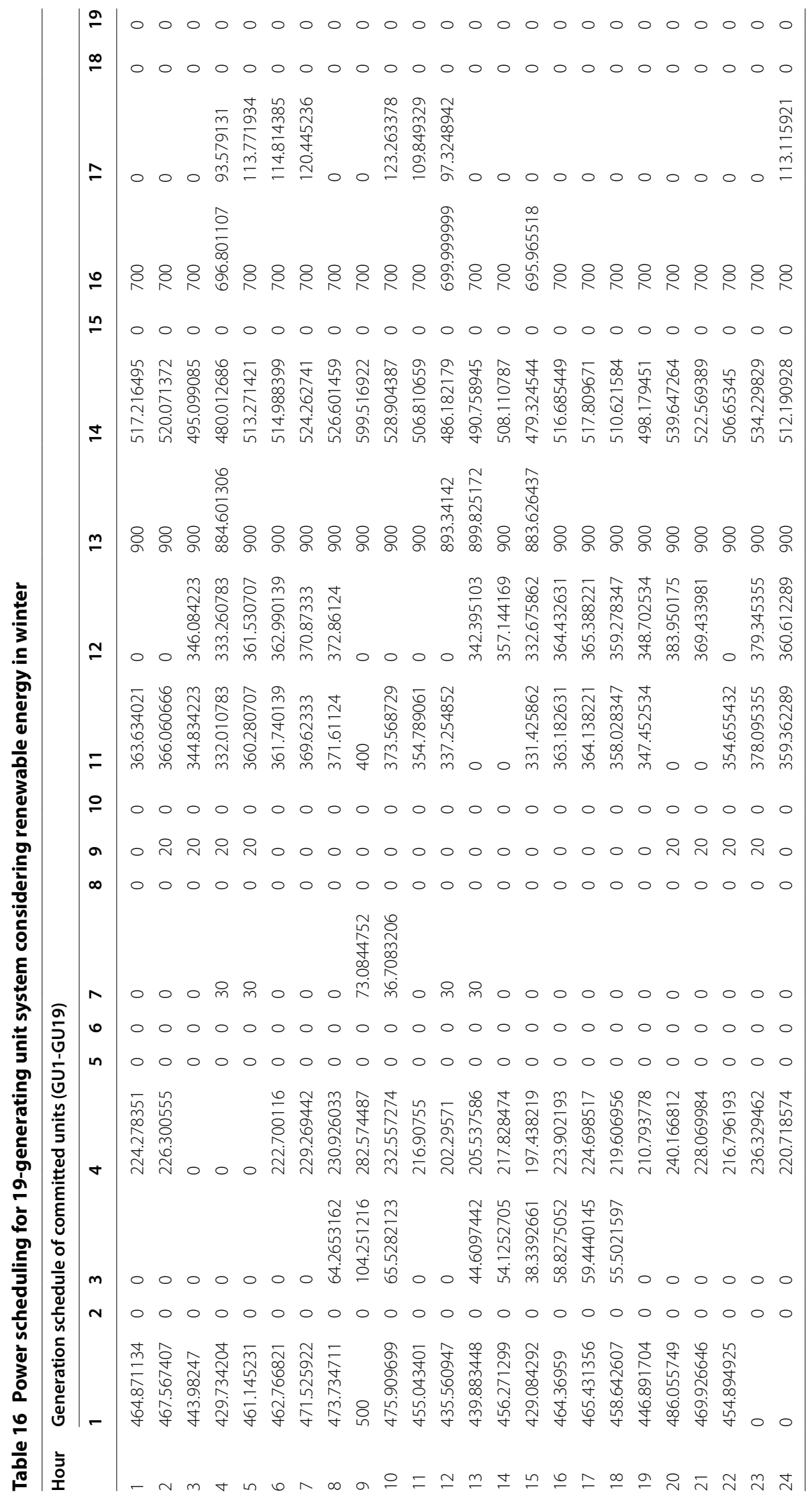




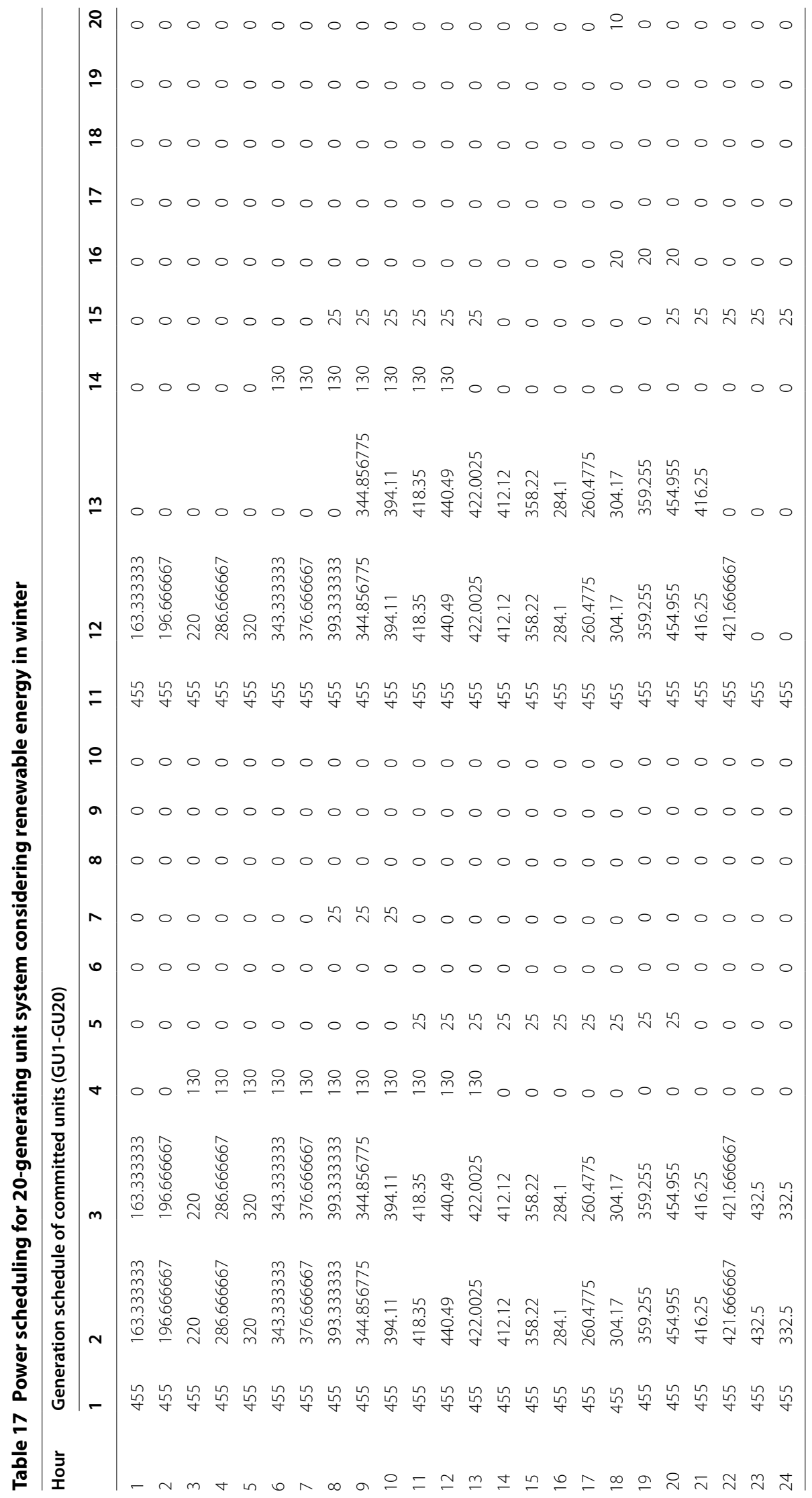









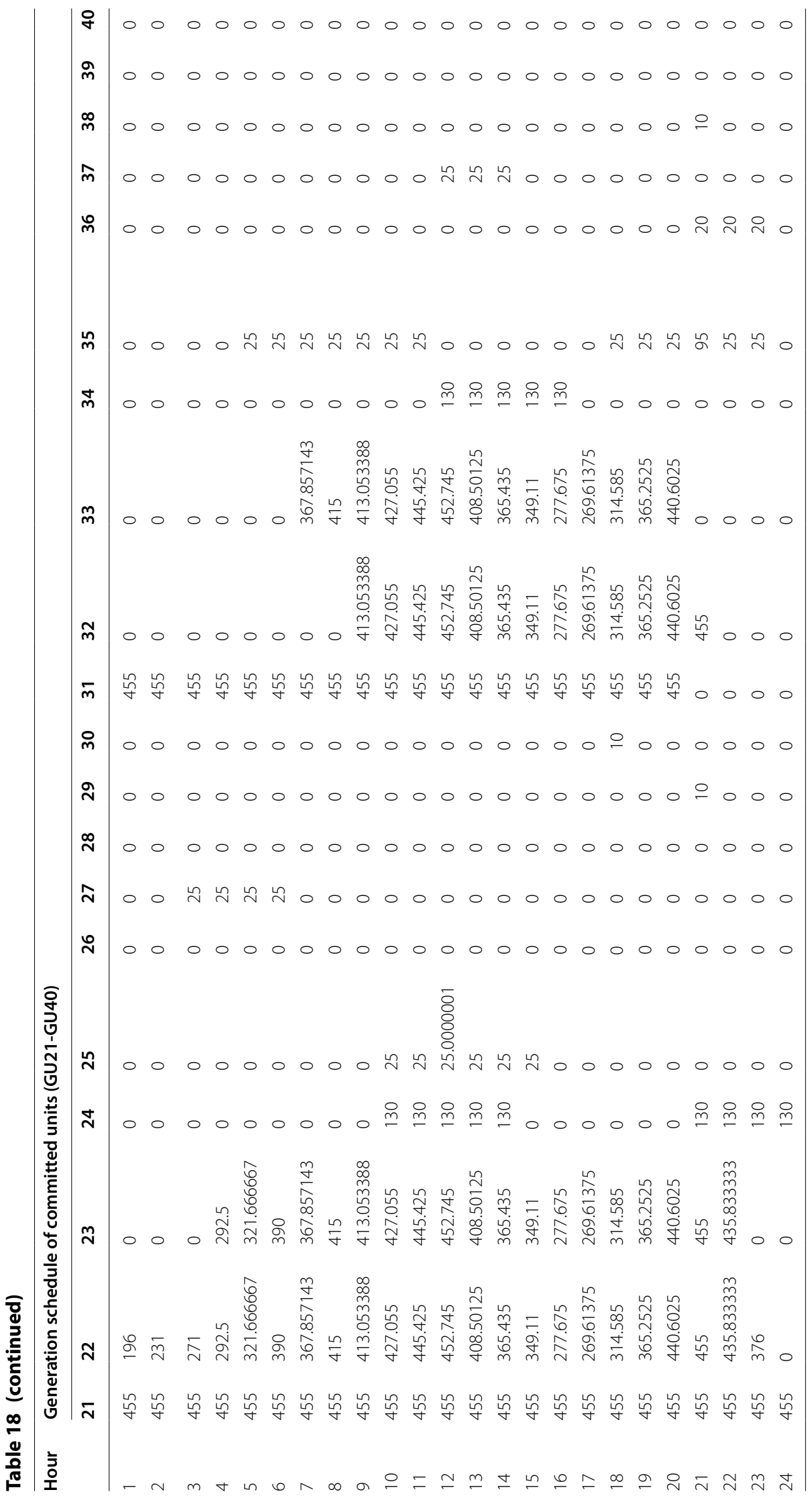









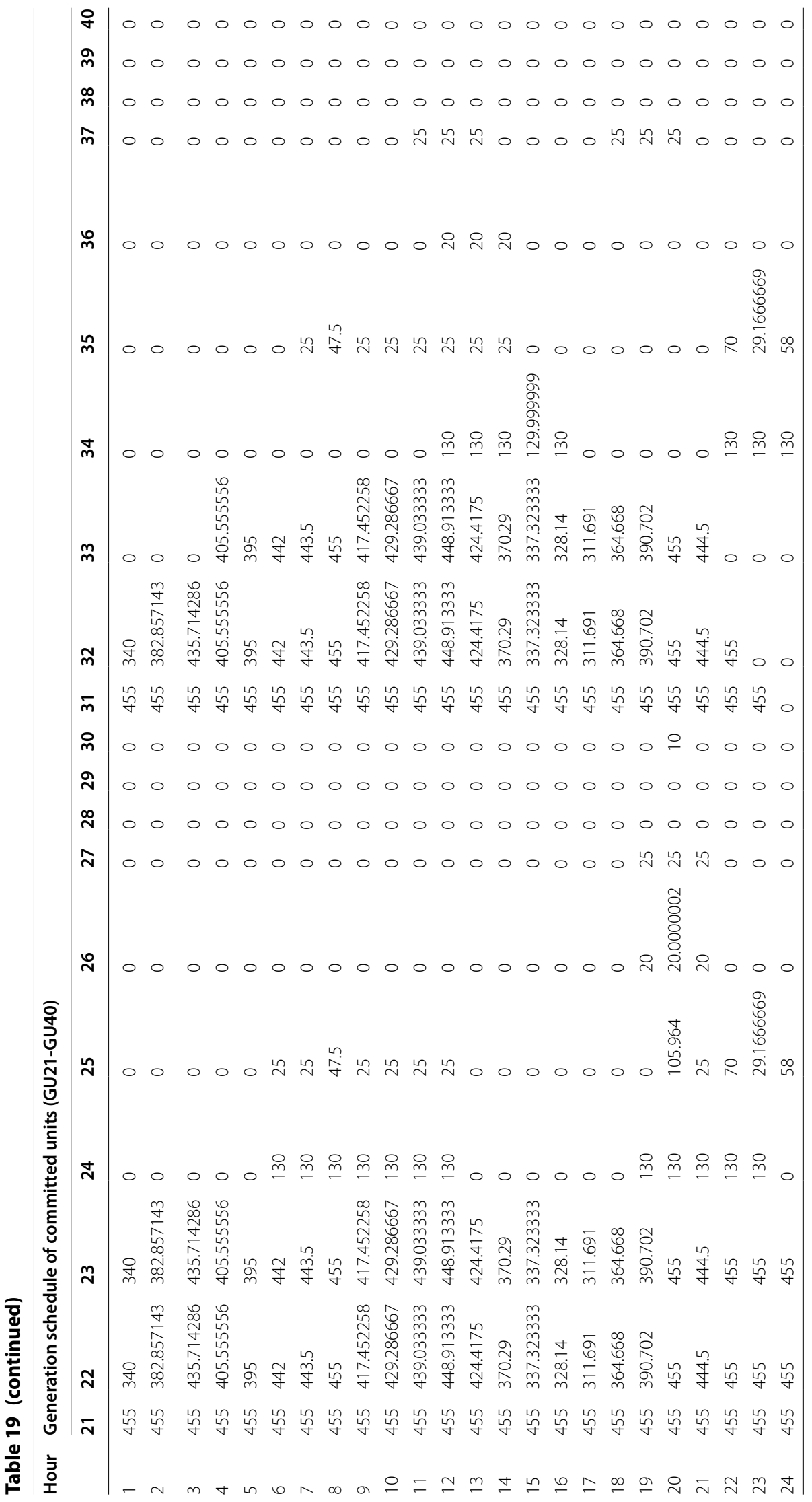




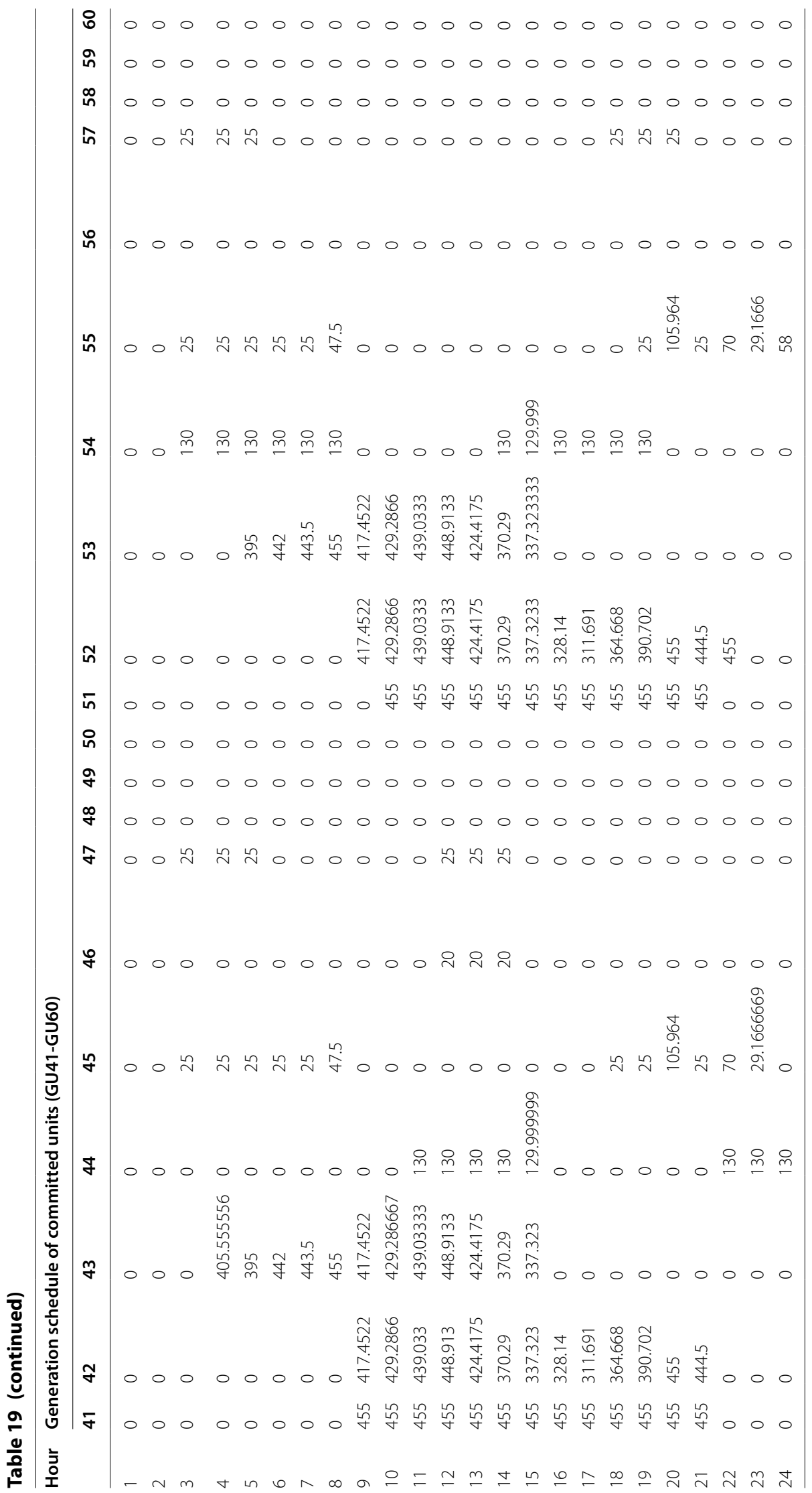




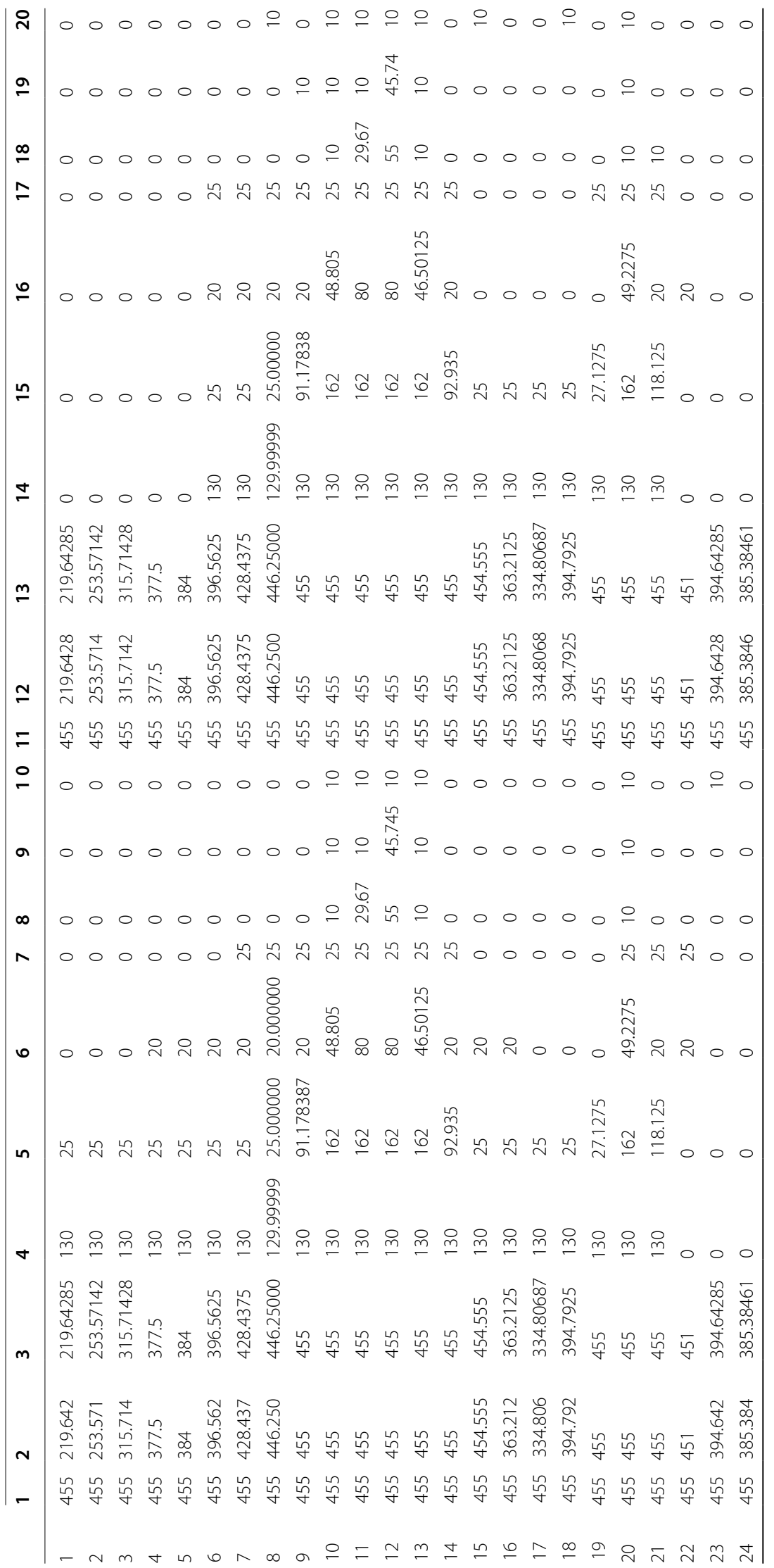




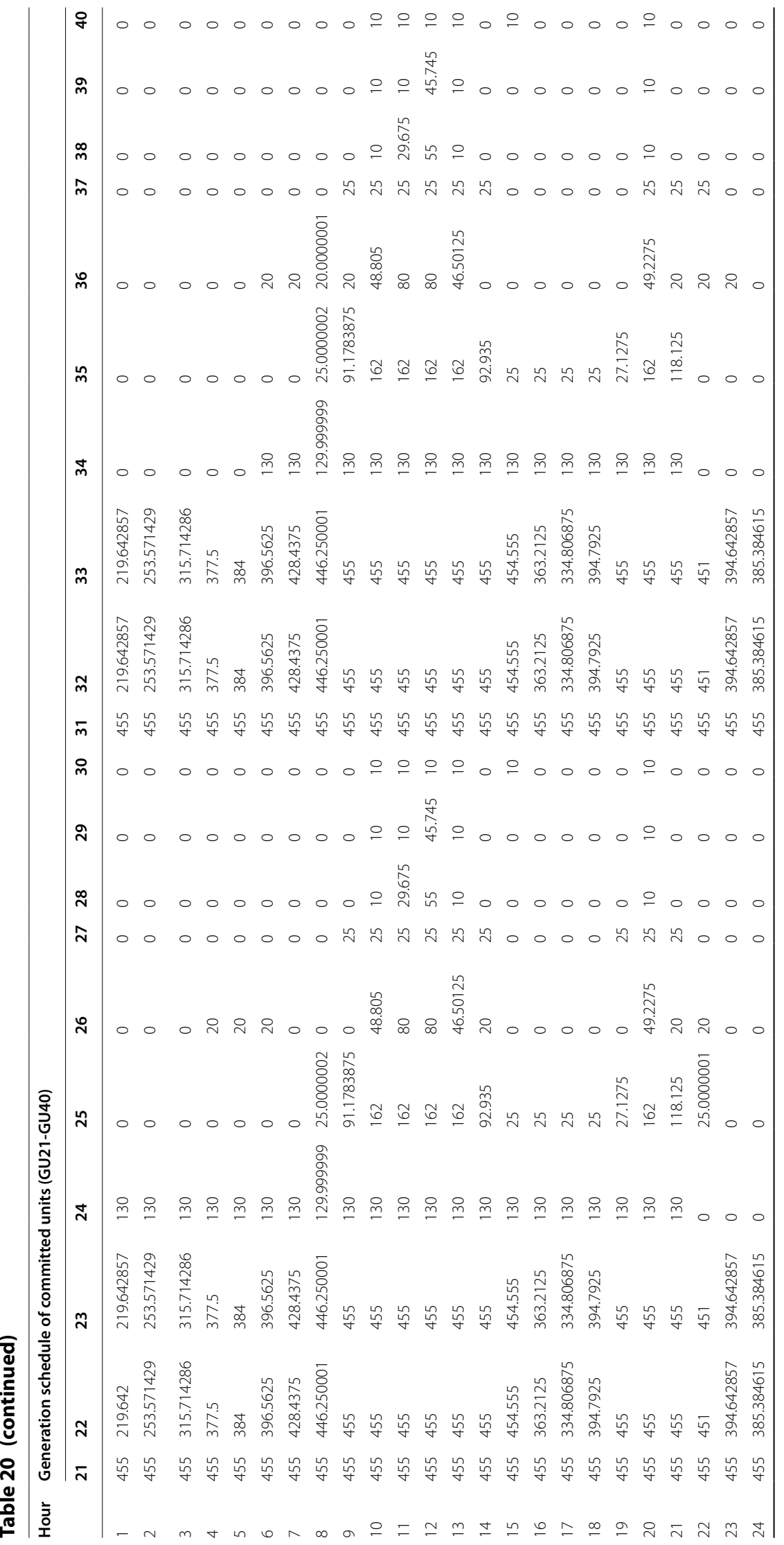




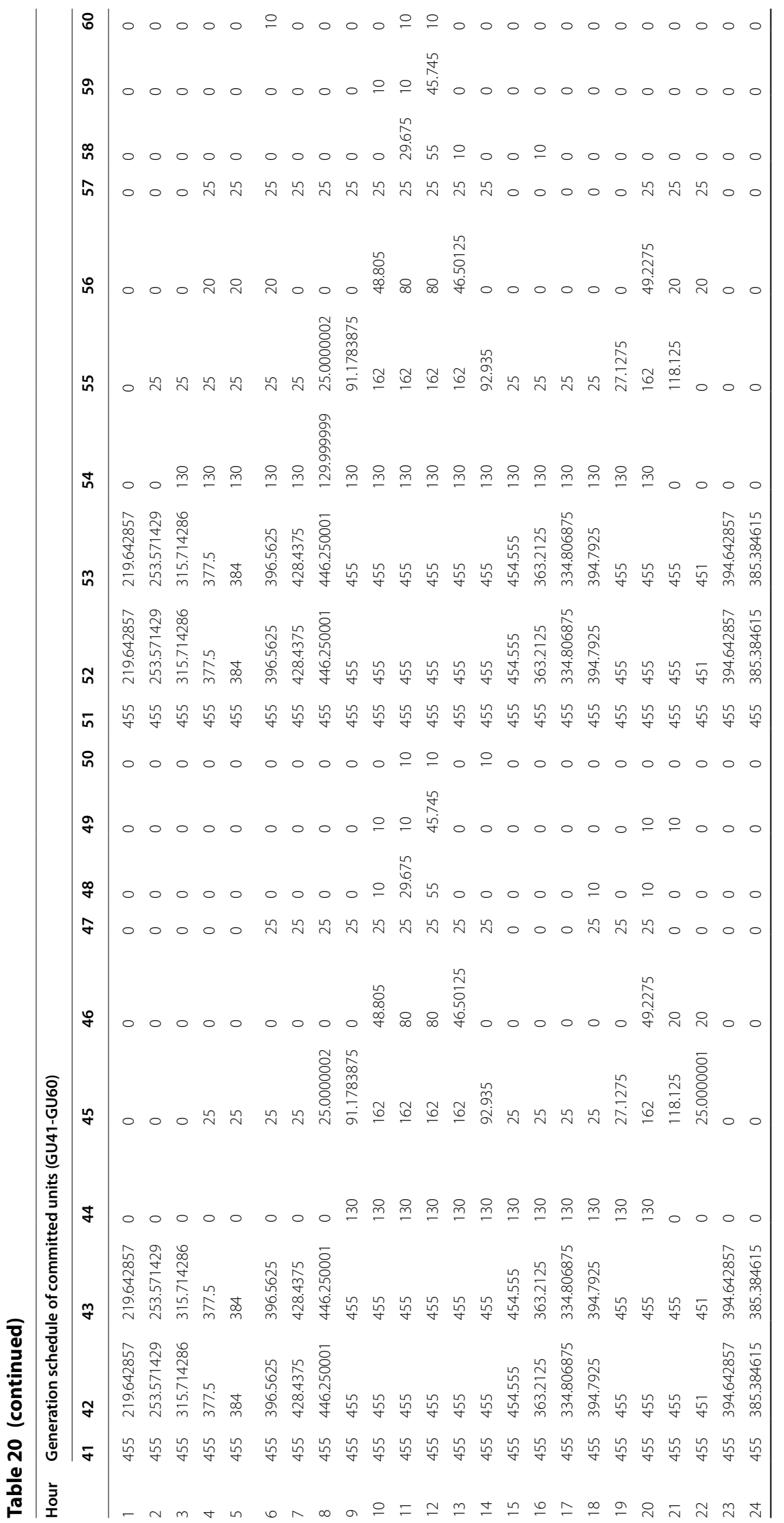




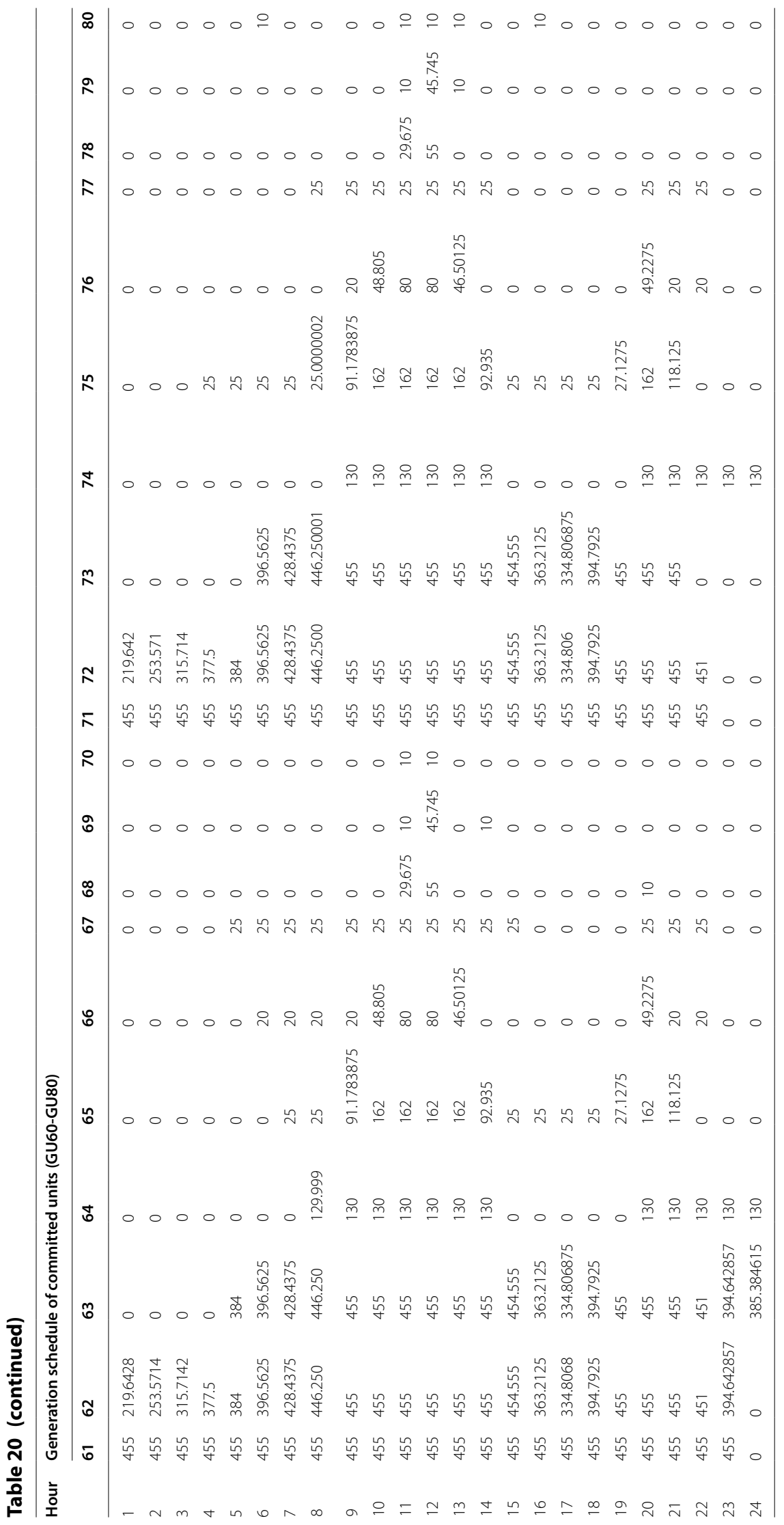




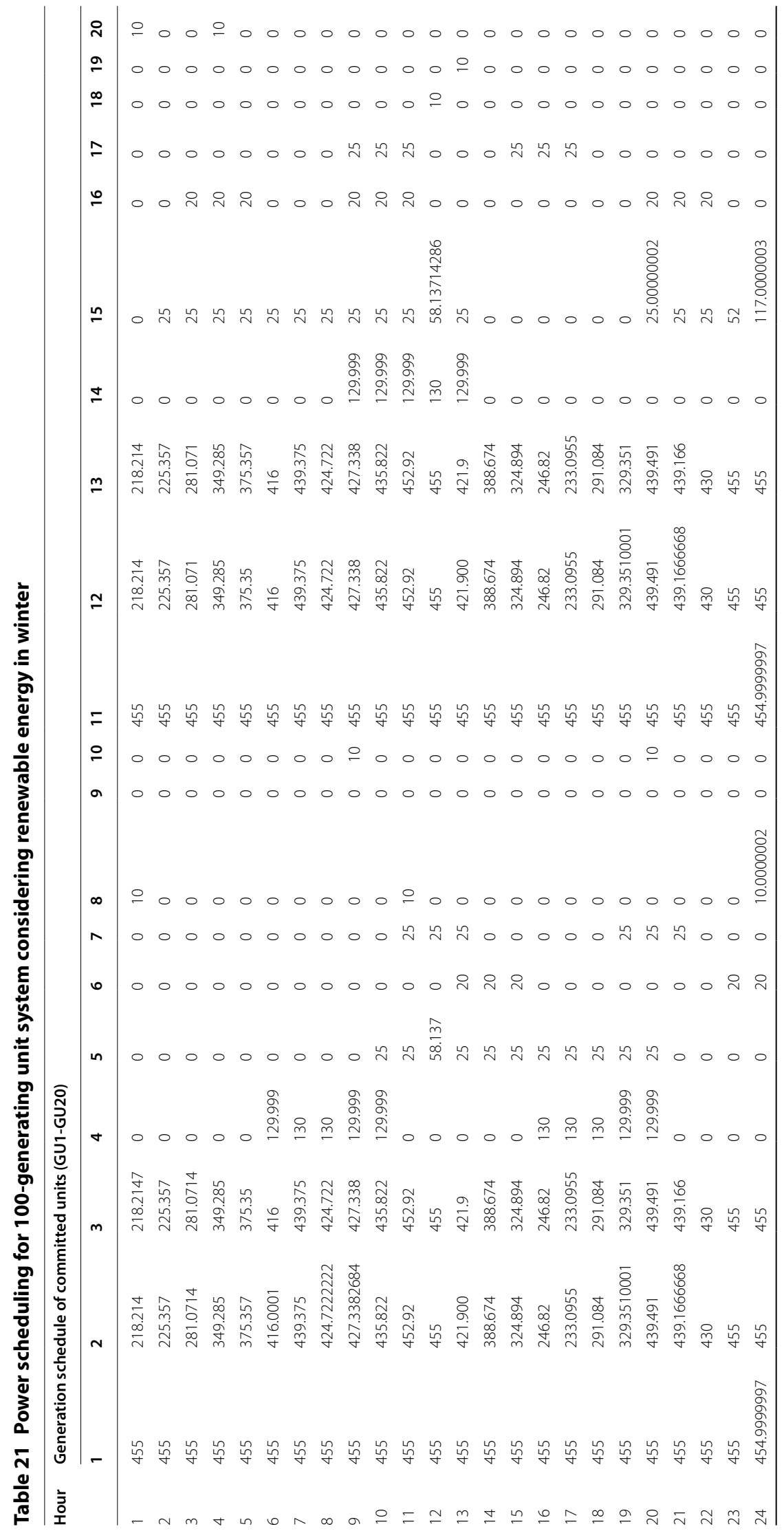




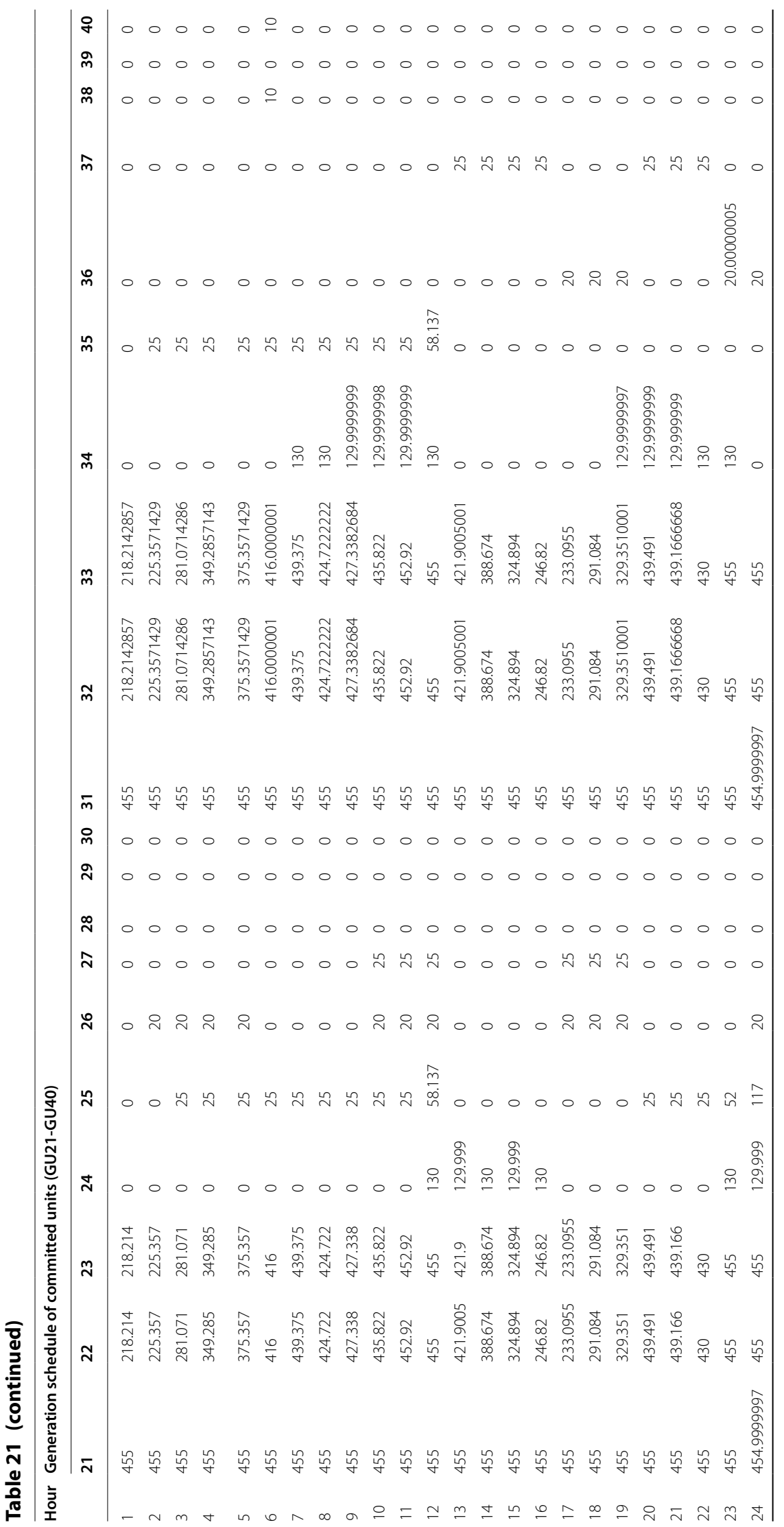




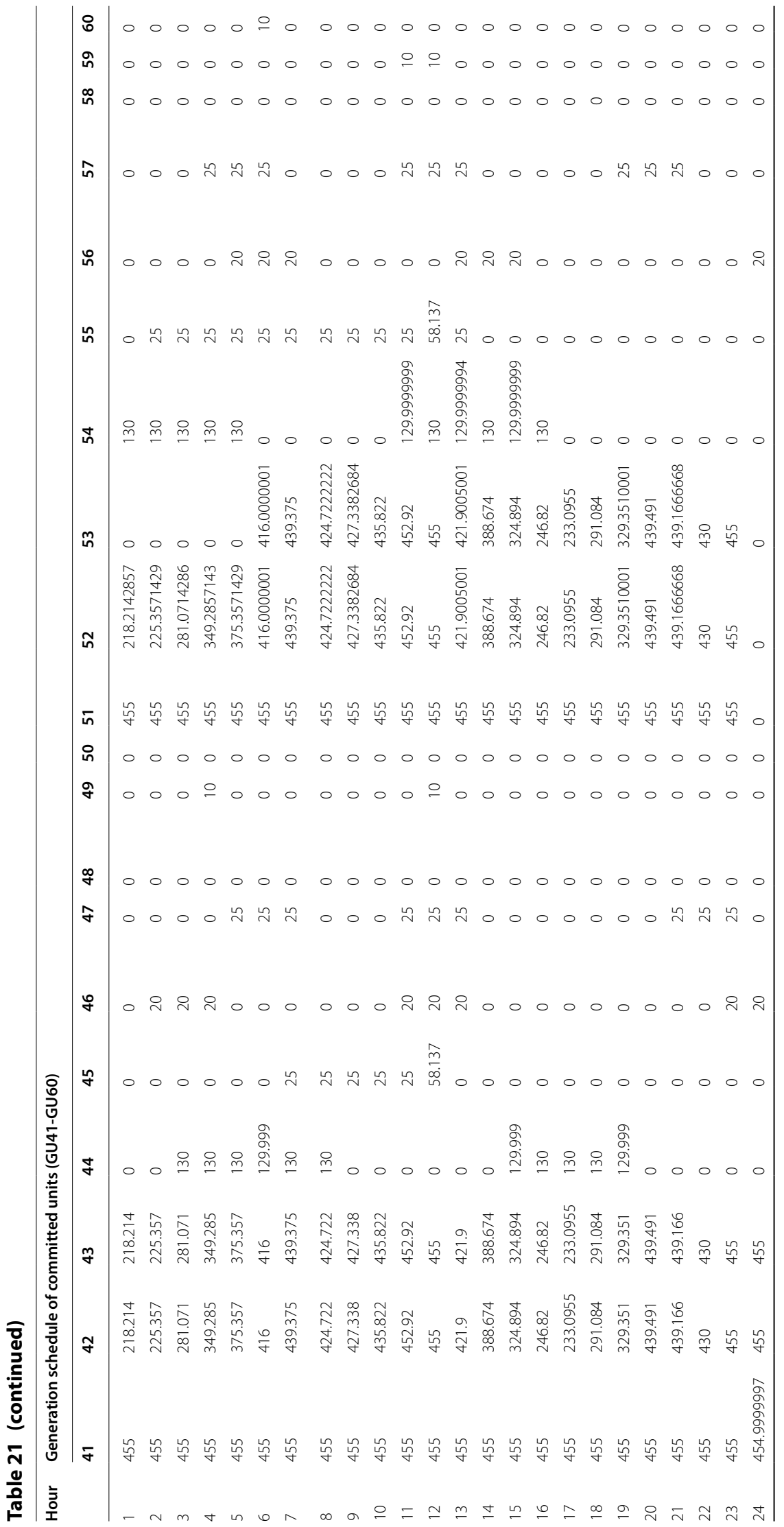




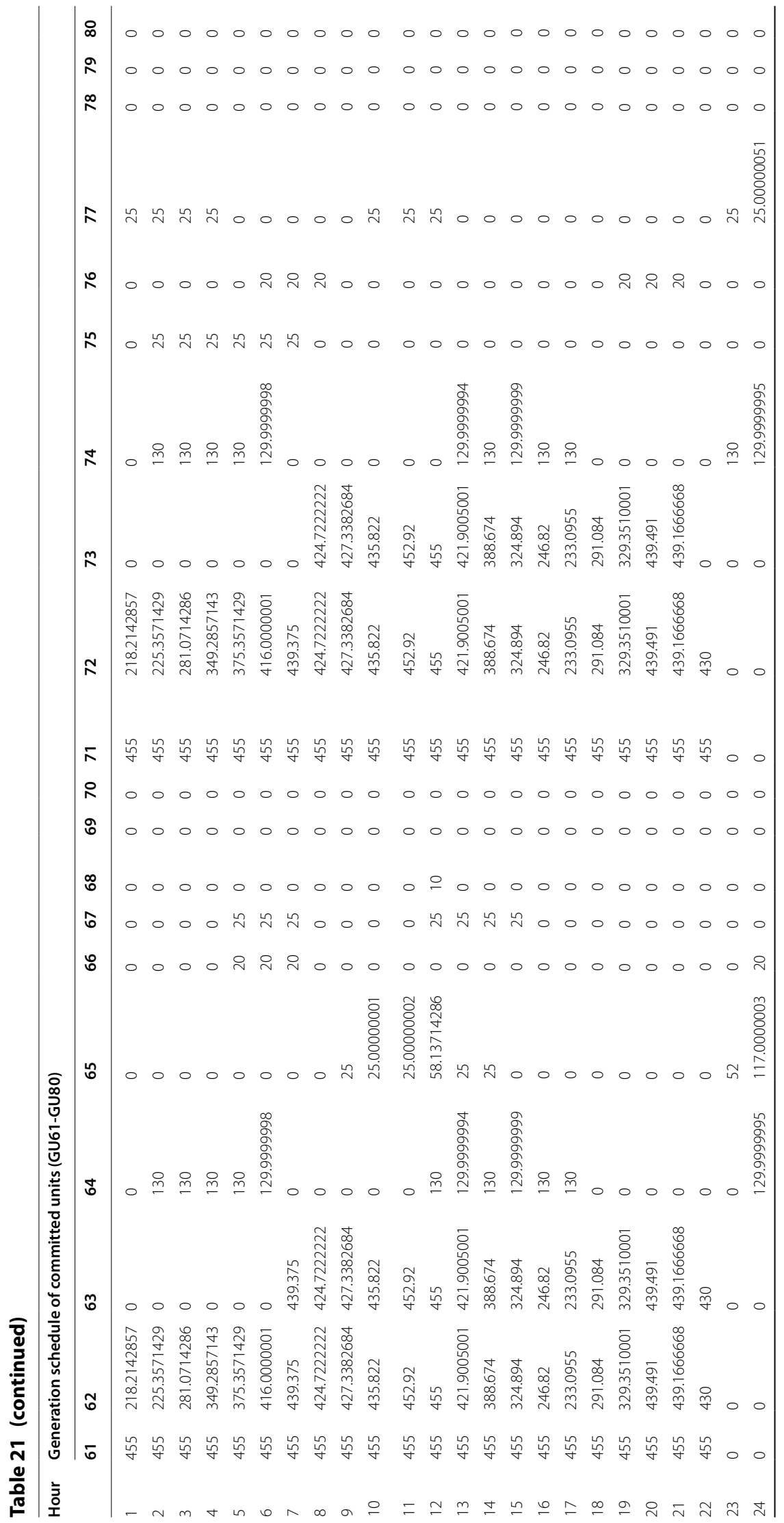




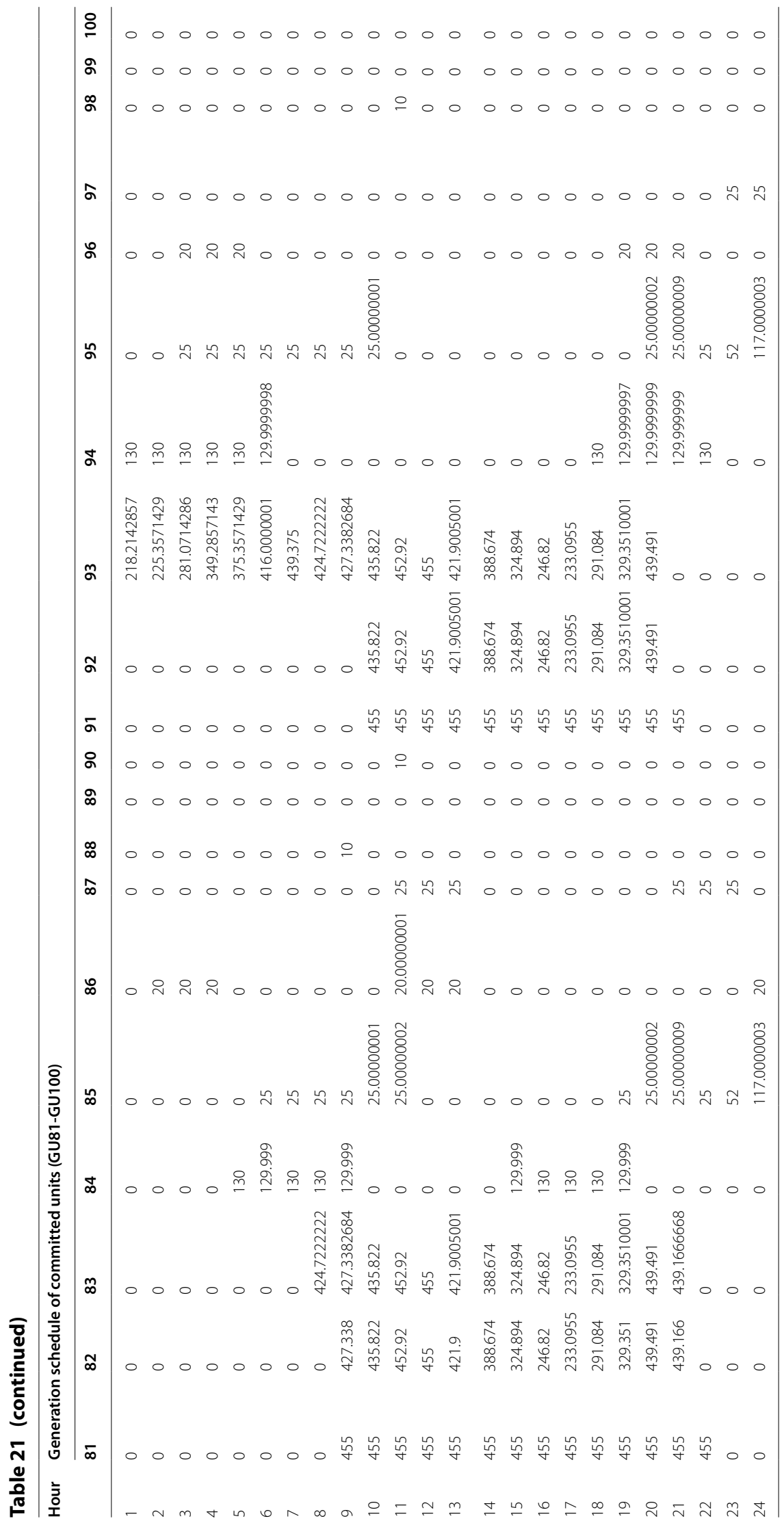


Table 22 Overall cost for generation of each unit without renewable energy sources

\begin{tabular}{ll}
\hline Generating units & Generation cost (\$) \\
\hline 5-Unit & 9010.1 \\
6-Unit & 13489.93957 \\
10-Unit (5\% SR) & 557533.12 \\
10-Unit (10\% SR) & 563937.6875 \\
19-Unit & 208510 \\
20-Unit & 1125200 \\
40-Unit & 2253700 \\
60-Unit & 3388100 \\
\hline
\end{tabular}

Table 23 Overall cost for generation of each unit with renewable energy sources in winter

\begin{tabular}{lll}
\hline Generating units & Generation cost (\$) & \% cost saving \\
\hline 5-Unit & 8572.9 & 4.85 \\
6-Unit & 12977 & 3.8 \\
10-Unit (5\% SR) & 536200 & 3.83 \\
10-Unit (10\% SR) & 539110 & 4.4 \\
19-Unit & 207560 & 0.46 \\
20-Unit & 1084100 & 3.65 \\
40-Unit & 2189400 & 2.85 \\
60-Unit & 3294600 & 2.76 \\
80-Unit & 5591700 & - \\
100-Unit & 5529900 & - \\
\hline
\end{tabular}

Table 24 Overall cost for generation of each unit with renewable energy sources in summer

\begin{tabular}{lll}
\hline Generating units & Generation cost (\$) & \% Cost saving \\
\hline 5-Unit & 8226.6 & 8.7 \\
6-Unit & 12229 & 9.35 \\
10-Unit (5\% SR) & 529980 & 4.94 \\
10-Unit (10\% SR) & 534050 & 5.3 \\
19-Unit & 207180 & 0.65 \\
20-Unit & 1076400 & 4.34 \\
40-Unit & 2176900 & 3.41 \\
60-Unit & 3297500 & 2.67 \\
80-Unit & 5578000 & - \\
100-Unit & 5530800 & - \\
\hline
\end{tabular}


Table 25 Overall cost for generation of each unit with renewable energy sources in Autumn \& Spring

\begin{tabular}{lll}
\hline Generating units & Generation cost (\$) & \% cost saving \\
\hline 5-Unit & 7880.4 & 12.5 \\
6-Unit & 11720 & 13.12 \\
10-Unit (5\% SR) & 526480 & 5.57 \\
10-Unit (10\% SR) & 529890 & 6.04 \\
19-Unit & 205610 & 1.4 \\
20-Unit & 1075300 & 4.43 \\
\hline
\end{tabular}

\section{Conclusions}

In this research work, the authors have successfully presented the fusion of Harris Hawks optimizer with SCA optimization technique and evaluated performance of the suggested hybrid optimized method for standard benchmark problem unit commitment problem, which consists of thermal generating units and along with PV generating units. The proposed research focuses on invention of hybrid variant of Harris Hawks optimizer (HHO) and sine-cosine algorithm (SCA) using memetic algorithm approach, named as intensify Harris Hawks optimizer. The efficacy of the suggested algorithm was tested for 4-generating unit system, 5-generating unit system, 6-generating unit system, 7-generating unit system, 10-generating unit system, 19-generating unit system, 20-generating unit system, 40-generating unit system and 60-generating unit system. After successful experiment, it was observed that the suggested optimizer is too much effective to solve continuous, discrete and nonlinear optimization problems.

After verification, it builds up the effective outcomes of the suggested hybrid improvement optimization which are more effective to other newly defined metaheuristics, hybrid and heuristics method and advancement search calculation and suggested algorithm recommends for the efficiency of this algorithm in the search area of meta-heuristics type optimization algorithms which are nature inspired. The other existing optimization techniques have good development prospect, but their research is still at initial condition and included so many problems which need to be solved or in other instance, there are several uncertainties, such as, how to adequately stay away from nearby or local optimum? What is the most effective method to consummately consolidate the upsides of distinctive enhancement calculations? How to successfully set the boundaries or parameter of a calculation? What are the compelling cycle of iteration stop conditions? etc. The most significant issue is that it comes up short on a bound together and complete hypothetical framework. So, using this novel proposed methodology, those problems are easily solved. The proposed optimization algorithm is useful to overcome those problems.

\section{Supplementary information}

The online version contains supplementary material available at https://doi.org/10.1186/s43067-020-00026-3.

Additional file 1. Test data for standard Unit Commitment Problems. 


\section{Abbreviations}

TFC: Total cost of fuel; $F_{\operatorname{cost} n}\left(P_{n t}\right)$ : Cost of fuel for a particular generating unit $n$th at that particular time' $t$ ' $h o u r ; S U C_{n, t}$ : Cost of start-up for $n$th unit within ' $t$ ' hours; SDC $n$ : Cost of Shutdown for $n$th unit within ' $t$ ' hours; $U_{n t}$ : Unit status at time t; $A_{n}$ : Coefficient of cost for $n$th unit; $B_{n}$ : Coefficient of cost for $n$th unit; $C_{n}$ : Coefficient of cost for $n$th unit; $H S U_{n}$ : hot start for $n$th unit; $\mathrm{CSU}_{n}$ : cold start for $n$th unit; $P_{n, t}^{\mathrm{MAX}}$ : Maximum electrical power generation by unit $n ; P_{n}^{\mathrm{MIN}}$ : Minimum electrical power which generation by unit $n ; P_{n, t}$ : Electrical power generation of unit $n$th at the time span ' $t$ '; $\mathrm{PD}_{t}$ : load demand at $t$ ' hours; $\mathrm{INS}_{n}$ : initial status of unit $n$ at time ' $t^{\prime} ; T_{n, t}^{\text {OFF. }}$ Initial OFF status for $n$th unit at time ' $t^{\prime} ; T_{n, t}^{\text {ON }}$ I Initial ON status for $n$th unit at time ' $t^{\prime}$; $T_{n}^{\text {UP: }}$ : UP condition for $n$ no. of power generating unit; $T_{n}^{D W}$ : DOWN condition for $n$ no. of power generating unit; $K$ : incremental cost for shut down of unit; $\mathrm{PD}_{n}$ : Power demand for $n$th unit; $\mathrm{SR}_{t}$ : spinning reserve necessity; $T_{n}^{C O L D}$ : Time span for COLD start of $\mathrm{n}$ no. of generating unit; Np: Population number; $t$ : No. of hours; NU: No. of generators.

\section{Acknowledgements}

The corresponding author wishes to thank Dr. O.P. Malik, Professor Emeritus, Department of Electrical and Computer Engineering, Schulich School of Engineering, University of Calgary, Calgary, Alberta, CANADA for continuous support, guidance, encouragement and for providing advance research facilities for post-doctorate research at the University of Calgary, Alberta, CANADA.

\section{Authors' contribution}

AN analyzed and interpreted the data regarding the optimal scheduling of each power generating unit during $24 \mathrm{~h}$ and overall cost for power generation of each unit with renewable energy sources in summer, winter, autumn and spring and also drafted the work or substantively revised it and was a major contributor in writing the manuscript. VK have made substantial contribution to the conception and design of the research work and the creation of MATLAB coding (Software) used in the work. All authors have read and approved the manuscript, and the content of the manuscript has not been published or submitted for publication elsewhere.

\section{Funding}

Not applicable.

\section{Availability of data and material}

The datasets used and/or analyzed during the current research study are available from the corresponding author on reasonable request.

\section{Competing interests}

The authors declare that they have no known competing financial interests or personal relationships that could have appeared to influence the work reported in this paper. The authors declare that they have no competing interests.

\section{Author details}

${ }^{1}$ School of Electronics and Electrical Engineering, Lovely Professional University, Punjab, India. ${ }^{2}$ School of Electronics and Electrical Engineering, Lovely Professional University, Phagwara, India. ${ }^{3}$ Department of Electrical and Computer Engineering, Schulich School of Engineering, University of Calgary, Alberta, Canada.

Received: 26 June 2020 Accepted: 15 December 2020

Published online: 03 March 2021

\section{References}

1. Gupta S, Deep K, Engelbrecht AP (2020) Engineering applications of artificial intelligence a memory guided sine cosine algorithm for global optimization. Eng Appl Artif Intell 93:103718

2. Heidari AA, Mirjalili S, Faris H, Aljarah I, Mafarja M, Chen H (2019) Harris hawks optimization: algorithm and applications. Future Gener Comput Syst 97:849-872

3. Chen H, Asghar A, Chen H, Wang M, Pan Z, Gandomi AH (2020) Multi-population differential evolution-assisted Harris hawks optimization: framework and case studies. Future Gener Comput Syst 111:175-198

4. Gupta S, Deep K, Moayedi H, Foong LK, Assad A (2020) Sine cosine grey wolf optimizer to solve engineering design problems. Eng Comput, no. 0123456789

5. Gupta S, Deep K, Mirjalili S, Hoon J (2020) "A modified sine cosine algorithm with novel transition parameter and mutation operator for global optimization. Expert Syst Appl 154:113395

6. Wolpert DH, Macready WG (1997) No free lunch theorems for optimization. IEEE Trans Evol Comput 1(1):67-82

7. Zhou W, Wang P, Heidari AA, Wang M, Chen H (2020) Multi-core sine cosine optimization: methods and inclusive analysis. Expert Syst Appl 164:113974

8. Kerr RH, Scheidt JL, Fontanna AJ, Wiley JK (1966) Unit commitment. IEEE Trans Power Appar Syst 5:417-421

9. Baldwin CJ, Dale KM, Dittrich RF (1959) A study of the economic shutdown of generating units in daily dispatch. AlEE Trans Power Appar Syst. 78:1272-1284

10. Lee KD, Vierra RH, Nagel GD, Jenkins RT (1985) Problems associated with unit. Commitment in uncertainty. IEEE Trans Power Appar Syst 104(8):2072-2078

11. Dorigo M, Birattari M, Stutzle T (2006) Ant colony optimization. IEEE Comput Intell Mag 1(4):28-39

12. Mirjalili S (2015) The ant lion optimizer. Adv Eng Softw 83:80-98

13. Mirjalili S, Lewis A (2014) Adaptive gbest-guided gravitational search algorithm. Neural Comput Appl 25(7-8):1569-1584 
14. Yang X-S (2010) New metaheuristic bat-inspired algorithm. In: Nature inspired cooperative strategies for optimization (NICSO 2010). Springer, pp 65-74

15. Simon D (2008) Biogeography-based optimization. IEEE Trans Evol Comput 12(6):702-713

16. Cohen Al, Yoshimura M (1983) A branch-and-bound algorithm for unit commitment. IEEE Trans Power Appar Syst 102(2):444-451

17. Nakamura RY, Pereira LA, Costa KA, Rodrigues D, Papa JP, Yang XS (2012) BBA: a binary bat algorithm for feature selection. In: Brazilian symposium on computer graphics and image processing, pp 291-297

18. Meng XB, Gao XZ, Lu L, Liu Y, Zhang H (2016) A new bio-inspired optimisation algorithm: Bird Swarm Algorithm. J Exp Theor Artif Intell 28(4):673-687

19. Das S, Biswas A, Dasgupta S, Abraham A (2009) Bacterial foraging optimization algorithm: theoretical foundations, analysis, and applications. Stud Comput Intell 203:23-55

20. Civicioglu P (2013) Backtracking Search Optimization Algorithm for numerical optimization problems. Appl Math Comput 219(15):8121-8144

21. Rashedi E, Nezamabadi-Pour H, Saryazdi S (2010) BGSA: binary gravitational search algorithm. Nat Comput 9(3):727-745

22. Kaveh A, Mahdavi VR (2015) Colliding bodies optimization: extensions and applications. Springer, Berlin, pp $1-284$

23. Gandomi AH, Yang X-S, Alavi AH (2013) Cuckoo search algorithm: a metaheuristic approach to solve structural optimization problems. Eng Comput 29(1):17-35

24. Wang GG, Guo L, Gandomi AH, Hao GS, Wang H (2014) Chaotic Krill Herd algorithm. Inf Sci (NY) 274:17-34

25. Kuo HC, Lin CH (2013) Cultural evolution algorithm for global optimizations and its applications. J Appl Res Technol 11(4):510-522

26. Mirjalili S (2016) Dragonfly algorithm: a new meta-heuristic optimization technique for solving single-objective, discrete, and multi-objective problems. Neural Comput Appl 27(4):1053-1073

27. Snyder WL, Powell HD, Rayburn JC (1987) Dynamic programming approach to unit commitment. IEEE Trans Power Syst 2:339-347

28. Wang GG, Deb S, Coelho LDS (2015) Earthworm optimization algorithm: a bio-inspired metaheuristic algorithm for global optimization problems. Int J Bio-Inspired Comput 1(1):1

29. Wang GG, Deb S, Coelho LDS (2016) Elephant herding optimization. In: 2015 3rd international symposium on computational and business intelligence (ISCBI 2015), pp 1-5

30. Abedinpourshotorban H, Mariyam Shamsuddin S, Beheshti Z, Jawawi DNA (2016) Electromagnetic field optimization: a physics-inspired metaheuristic optimization algorithm. Swarm Evol Comput 26:8-22

31. Ghorbani N, Babaei E (2014) Exchange market algorithm. Appl Soft Comput J 19(April):177-187

32. Ghaemi M, Feizi-Derakhshi MR (2014) Forest optimization algorithm. Expert Syst Appl 41(15):6676-6687

33. Tan Y, Tan Y, Zhu Y (2015) Fireworks algorithm for optimization fireworks algorithm for optimization, pp 355-364

34. Yang XS (2012) Flower pollination algorithm for global optimization. In: Unconventional computation and natural computation. Springer, pp 240-249

35. Rashedi E, Nezamabadi-Pour H, Saryazdi S (2009) GSA: a gravitational search algorithm. Inf Sci 179:2232

36. Kazarlis SA (1996) A genetic algorithm solution to the unit commitment problem. IEEE Trans Power Systems 11:83-92

37. Yang XS (2010) Firefly algorithm. In: Engineering optimization, p 22

38. Saremi S, Mirjalili S, Lewis A (2017) Grasshopper optimisation algorithm: theory and application. Adv Eng Softw 105:30-47

39. Mirjalili S, Mirjalili SM, Lewis A (2014) Grey Wolf optimizer. Adv Eng Softw 69:46-61

40. Dai C, Chen W, Ran L, Zhang Y, Du Y (2011) Human group optimizer with local search, pp 310-320

41. Dieu VN, Ongsakul W (2008) Ramp rate constrained unit commitment by improved priority list and augmented Lagrange Hopfield network. Electr Power Syst Res 78(3):291-301

42. Gandomi AH (2014) Interior search algorithm (ISA): a novel approach for global optimization. ISA Trans 53(4):1168-1183

43. Atashpaz-Gargari E, Lucas C (2007) Imperialist competitive algorithm: an algorithm for optimization inspired by imperialistic competition. In: Proceedings of the IEEE congress on evolutionary computation, CEC 2007, pp 4661-4667

44. Gandomi AH, Alavi AH (2012) Krill herd: a new bio-inspired optimization algorithm. Commun Nonlinear Sci Numer Simul 17(12):4831-4845

45. Karimkashi S, Kishk AA (2010) Invasive weed optimization and its features in electromagnetics. IEEE Trans Antennas Propag 58(4):1269-1278

46. Shareef H, Ibrahim AA, Mutlag AH (2015) Lightning search algorithm. Appl Soft Comput J 36:315-333

47. Kashan AH (2014) League Championship Algorithm (LCA): an algorithm for global optimization inspired by sport championships. Appl Soft Comput J 16:171-200

48. Mirjalili S, Mirjalili SM, Hatamlou A (2016) Multi-verse optimizer: a nature-inspired algorithm for global optimization. Neural Comput Appl 27(2):495-513

49. Reza Norouzi M, Ahmadi A, Esmaeel Nezhad A, Ghaedi A (2014) Mixed integer programming of multi-objective security-constrained hydro/thermal unit commitment. Renew Sustain Energy Rev 29:911-923

50. Sadollah A, Bahreininejad A, Eskandar H, Hamdi M (2012) Mine blast algorithm: a new population based algorithm for solving constrained engineering optimization problems. Appl Soft Comput J 13:2592-2612

51. Mirjalili S (2015) Knowledge-Based Systems Moth-flame optimization algorithm: a novel nature-inspired heuristic paradigm. Knowl-Based Syst 89:228-249

52. Kirkpatrick S, Gelatt CD, Vecchi MP (1983) Optimization by simulated annealing. Science 220(4598):671-680

53. Wang GG, Deb S, Cui Z (2015) Monarch butterfly optimization. Neural Comput Appl 31:1995-2014 
54. Kennedy J, Eberhart RC (1995) Particle Swarm Optimization. In: Proceedings of the IEEE international conference on neural networks, pp 1942-1948

55. Gupta S, Deep K (2018) A novel random walk grey wolf optimizer. Swarm Evol Comput 44:101-112

56. Husseinzadeh Kashan A (2014) A new metaheuristic for optimization: optics inspired optimization (OIO). Comput Oper Res 55:99-125

57. Merrikh-Bayat F (2015) The runner-root algorithm: a metaheuristic for solving unimodal and multimodal optimization problems inspired by runners and roots of plants in nature. Appl Soft Comput J 33:292-303

58. Mirjalili S (2016) SCA: a sine cosine algorithm for solving optimization problems. Knowl-Based Syst 96:120-133

59. Anita JM, Raglend IJ (2012) Shuffled Frog Leaping Algorithm. In: International conference on computing, electronics and electrical technologies, pp 109-115

60. Salimi H (2015) Stochastic fractal search: a powerful metaheuristic algorithm. Knowl-Based Syst 75:1-18

61. Dai C, Zhu Y, Chen W (2007) Seeker optimization algorithm, pp 167-176

62. Satapathy SC, Naik A, Parvathi K (2013) A teaching learning based optimization based on orthogonal design for solving global optimization problems, pp 1-12

63. Cheng MY, Prayogo D (2014) Symbiotic organisms search: a new metaheuristic optimization algorithm. Comput Struct 139:98-112

64. Gonçalves MS, Lopez RH, Fleck L, Miguel F (2015) Search group algorithm: a new metaheuristic method for the optimization of truss structures. Comput Struct 153:165-184

65. Mirjalili S, Gandomi AH, Mirjalili SZ, Saremi S, Faris H, Mirjalili SM (2017) Salp swarm algorithm: a bio-inspired optimizer for engineering design problems. Adv Eng Softw 114:163-191

66. Mirjalili S, Lewis A (2016) The whale optimization algorithm. Adv Eng Softw 95:51-67

67. Baykasoğlu A, Akpinar \$ (2017) Weighted Superposition Attraction (WSA): a swarm intelligence algorithm for optimization problems - part 1: unconstrained optimization. Appl Soft Comput J 56:520-540

68. Li MD, Zhao H, Weng XW, Han T (2016) A novel nature-inspired algorithm for optimization: virus colony search. Adv Eng Softw 92:65-88

69. Zheng YJ (2015) Water wave optimization: a new nature-inspired metaheuristic. Comput Oper Res 55:1-11

70. Glover F (1989) Tabu search—part I. ORSA J Comput 1:190

71. Eskandar H, Sadollah A, Bahreininejad A, Hamdi M (2012) Water cycle algorithm—a novel metaheuristic optimization method for solving constrained engineering optimization problems. Comput Struct 110-111:151-166

72. Bayraktar Z, Komurcu M, Werner DH (2010) Wind driven optimization (WDO): a novel nature-inspired optimization algorithm and its application to electromagnetics, no 1, pp 0-3

73. Gupta S, Deep K (2018) PT US CR. Expert Syst Appl

74. Gupta S, Deep K (2018) Improved sine cosine algorithm with crossover scheme for global optimization." KnowlBased Syst

75. Gupta S, Deep K (2019) Enhanced leadership_inspired grey wolf optimizer for global optimization problems. Eng Comput, no 0123456789

76. Gupta S, Deep K (2019) Hybrid grey wolf optimizer with mutation operator. Springer, Singapore

77. Gupta S, Deep K (2020) A memory-based grey wolf optimizer for global optimization tasks. Appl Soft Comput J 93:106367

78. Xu Z, Hu Z, Heidari AA, Wang M, Zhao X, Chen H, Cai X (2020) Orthogonally-designed adapted grasshopper optimization: a comprehensive analysis. Expert Syst Appl 150:113282

79. Sattar D, Salim R (2020) A smart metaheuristic algorithm for solving engineering problems. Eng Comput, no 0123456789

80. Banerjee N (2019) HC-PSOGWO: hybrid crossover oriented PSO and GWO based co-evolution for global optimization, vol 7, pp 3-8

81. Shahrouzi M, Salehi A (2020) Imperialist competitive learner-based optimization: a hybrid method to solve engineering problems. Iran Univ Sci Technol 10(1):155-180

82. Herwan M, Mustaffa Z, Mawardi M, Daniyal H (2020) Engineering applications of artificial intelligence barnacles mating optimizer: a new bio-inspired algorithm for solving engineering optimization problems. Eng Appl Artif Intell 87:103330

83. Faramarzi A, Heidarinejad M, Stephens B, Mirjalili S (2019) Equilibrium optimizer: a novel optimization algorithm. Knowl-Based Syst 191:105190

84. Muhammed DA, Saeed SAM, Rashid TA, Member I (2020) Improved algorithm fitness—dependent optimizer, vol XX

85. Panda N (2019) Improved spotted hyena optimizer with space transformational search for training pi-sigma higher order neural network, pp 1-31

86. Fan Q, Chen Z, Li Z, Xia Z, Yu J, Wang D (2020) A new improved whale optimization algorithm with joint search mechanisms for high-dimensional global optimization problems. Eng Comput, 0123456789

87. Chen H, Wang M, Zhao X (2020) A multi-strategy enhanced sine cosine algorithm for global optimization and constrained practical engineering problems. Appl Math Comput 369:124872

88. Yimit A, ligura K, Hagihara Y (2020) Refined selfish herd optimizer for global optimization problems. Expert Syst Appl 139:112838

89. Kamboj VK, Nandi A, Bhadoria A, Sehgal S (2019) An intensify Harris Hawks optimizer for numerical and engineering optimization problems. Appl Soft Comput J 89:106018

90. Zhao W, Wang L (2019) Artificial ecosystem-based optimization: a novel nature-inspired meta-heuristic algorithm, vol 0123456789 . Springer, London

91. 2019_I-GWO and EX-GWO.pdf

92. Khatri A, Gaba A, Vineet KPSR (2019) A novel life choice-based optimizer. Soft Comput, 0123456789

93. 2019_Multi-objective heat transfer search algorithm.pdf

94. Wang R, Wang J (2019) Simplified salp swarm algorithm. In: 2019 IEEE international conference on artificial intelligence and computer applications, pp 226-230 
95. Chen X, Tianfield H, Li K (2019) Self-adaptive differential artificial bee colony algorithm for global optimization problems. Swarm Evol Comput 45:70-91

96. Deka D, Datta D (2019) Optimization of unit commitment problem with ramp-rate constraint and wrap-around scheduling. Electr Power Syst Res 177:105948

97. Singh HP, Brar YS, Kothari DP (2019) Solution of optimal power flow based on combined active and reactive cost using particle swarm. Int J Electr Eng Technol 10(2):98-107

98. Bhadoria A, Marwaha S, Kumar V (2019) An optimum forceful generation scheduling and unit commitment of thermal power system using sine cosine algorithm. Neural Comput Appl 8

99. Srikanth K, Panwar LK, Panigrahi BK, Herrera-Viedma E, Sangaiah AK, Wang GG (2018) Unit commitment problem solution in power system using a new meta-heuristic framework: quantum inspired binary grey wolf optimizer

100. Premrudeepreechacharn S, Siritaratiwat A (2019) Unit commitment problem, pp 1-23

101. Bhadoria A, Kamboj VK (2018) Optimal generation scheduling and dispatch of thermal generating units considering impact of wind penetration using hGWO-RES algorithm. Appl Intell

102. Ramu M, Srinivas LR, Kalyani ST (2017) Gravitational search algorithm for solving unit, vol 5, no Xi, pp 1497-1502

103. Selvakumar K, Vijayakumar K, Sattianadan D, Boopathi CS (2016) Shuffled frog leaping algorithm (SFLA) for short term optimal scheduling of thermal units with emission limitation and prohibited operational zone (POZ) constraints, vol 9

104. Shukla A, Singh SN (2016) Multi-objective unit commitment using search space-based crazy particle swarm optimisation and normal boundary intersection technique, vol 10, pp 1222-1231

105. Saravanan B, Kumar C, Kothari DP (2016) Electrical power and energy systems a solution to unit commitment problem using fire works algorithm. Int J Electr Power Energy Syst 77:221-227

106. Kumar V, Bath KSK (2015) Hybrid HS—random search algorithm considering ensemble and pitch violation for unit commitment problem. Neural Comput Appl 28(5):1123-1148

107. Shukla A, Singh SN (2016) Advanced three-stage pseudo-inspired weight-improved crazy particle swarm optimization for unit commitment problem. Energy 96:23-36

108. Khorramdel H, Membe S, Aghaei J, Member S, Khorramdel B (2015) Optimal battery sizing in microgrids using probabilistic unit commitment. IEEE Trans Ind Inform 3203(c):1-11

109. Xing $H$, Cheng $H$, Zhang $L$ (2015) Demand response based and wind farm integrated economic dispatch. CSEE J Power Energy Syst 1(4):37-41

110. Kamboj VK, Bath SK, Dhillon JS (2017) A novel hybrid DE-random search approach for unit commitment problem. Neural Comput. Appl 28(7):1559-1581

111. Kamboj VK (2015) A novel hybrid PSO-GWO approach for unit commitment problem. Neural Comput. Appl. 27(6):1643-1655

112. Casolino GM, Liuzzi G, Losi A (2015) Electrical power and energy systems combined cycle unit commitment in a changing electricity market scenario. Int J Electr Power Energy Syst 73:114-123

113. Quan H, Srinivasan D, Khambadkone AM, Khosravi A (2015) A computational framework for uncertainty integration in stochastic unit commitment with intermittent renewable energy sources. Appl Energy 152:71-82

114. Zhang N, Hu Z, Han X, Zhang J, Zhou Y (2015) Electrical power and energy systems a fuzzy chance-constrained program for unit commitment problem considering demand response, electric vehicle and wind power. Int J Electr Power Energy Syst 65:201-209

115. Singhal PK, Naresh R, Sharma V (2015) A modified binary artificial bee colony algorithm for ramp rate constrained unit commitment problem. Int Trans Electr Energy Syst 25(12):3472-3491

116. Anita JM, Raglend IJ (2014) Multi objective combined emission constrained unit commitment problem using improved shuffled frog leaping algorithm Vindhya Group of Institutions mathematical modeling of emission constrained UC and, vol 13, pp 560-574

117. Ji B, Yuan X, Li X, Huang Y, Li W (2014) Application of quantum-inspired binary gravitational search algorithm for thermal unit commitment with wind power integration. Energy Convers Manag 87:589-598

118. Marko Č, Volkanovski A (2015) Engineering applications of artificial intelligence multi-objective unit commitment with introduction of a methodology for probabilistic assessment of generating capacities availability. Eng Appl Artif Intell 37:236-249

119. Gharegozi A, Jahani R (2013) A new approach for solving the unit commitment problem by cuckoo search algorithm. Indian J Sci Technol 6(9):5235-5241

120. Marko C (2013) Electrical power and energy systems a new model for optimal generation scheduling of power system considering generation units availability. Int J Electr Power Energy Syst 47:129-139

121. Todosijevi R, Crévits I (2012) VNS based heuristic for solving the unit commitment problem. Electron Notes Discrete Math 39:153-160

122. Anita JM, Raglend IJ, Kothari DP (2012) Solution of unit commitment problem using shuffled frog leaping algorithm, vol 1, no 4, pp 9-26

123. Saurabh S, Ahmed M (2018) Optimization method for unit commitment in high-level wind generation and solar power. Springer, Singapore

124. Safari A, Shahsavari H (2018) Frequency-constrained unit commitment problem with considering dynamic ramp rate limits in the presence of wind power generation. Neural Comput Appl 0123456789

125. Varghese MP, Amudha A (2018) Artificial bee colony and cuckoo search algorithm for cost estimation with wind power energy, pp 1-8

126. Govardhan M, Roy R, Govardhan M, Roy R (2016) Electric power components and systems comparative analysis of economic viability with distributed energy resources on unit commitment comparative analysis of economic viability with distributed energy resources on unit commitment, vol 5008

127. Navin NK (2016) A modified differential evolution approach to PHEV integrated thermal unit commitment problem

128. Wang W, Li C, Liao X, Qin H (2017) Study on unit commitment problem considering pumped storage and renewable energy via a novel binary artificial sheep algorithm. Appl Energy 187:612-626 
129. Banumalar K, Manikandan BV, Chandrasekaran K (2016) Security constrained unit commitment problem employing artificial computational intelligence for wind-thermal power system

130. Govardhan M, Roy R (2015) Electrical power and energy systems economic analysis of unit commitment with distributed energy resources. Int J Electr Power Energy Syst 71:1-14

131. Osório GJ, Lujano-rojas JM, Matias JCO, Catalão JPS (2015) Electrical power and energy systems a new scenario generation-based method to solve the unit commitment problem with high penetration of renewable energies. Int J Electr Power Energy Syst 64:1063-1072

132. Ming Z, Kun Z, Liang W (2014) Electrical power and energy systems study on unit commitment problem considering wind power and pumped hydro energy storage. Int J Electr Power Energy Syst 63:91-96

133. Scholar PG (2013) LR-PSO method of generation scheduling problem for thermal-wind-solar energy system in deregulated power system

134. Maghsudlu S, Mohammadi S (2018) Optimal scheduled unit commitment considering suitable power of electric vehicle and optimal scheduled unit commitment considering suitable power of electric vehicle and photovoltaic uncertainty. J Renew Sustain Energy 10(4):043705

135. Shahbazitabar M, Abdi H (2018) A novel priority-based stochastic unit commitment considering renewable energy sources and parking lot cooperation. Energy 161:308-324

136. Rahiman F, Mohd P, Othman F, Ottukuloth S (2018) Power station scheduling with energy storage. J Inst Eng Ser B 100(1):77-83

137. Ma K, Hu S, Yang J, Xu X, Guan X (2017) Appliances scheduling via cooperative multi-swarm PSO under day-ahead prices and photovoltaic generation. Appl Soft Comput J 62:504-513

138. Quan H, Srinivasan D, Khosravi A (2016) Integration of renewable generation uncertainties into stochastic unit commitment considering reserve and risk: a comparative study. Energy 103:735-745

139. Abujarad SY, Mustafa MW, Jamian JJ (2017) Recent approaches of unit commitment in the presence of intermittent renewable energy resources: a review. Renew Sustain Energy Rev 70:215-223

140. Selvakumar K, Vignesh B, Boopathi CS, Kannan T (2016) Thermal unit commitment strategy integrated with solar energy system. Int J Appl Eng Res 11(9):6856-6860

141. Jasmin EA, Ahamed TI, Remani T (2016) A function approximation approach to reinforcement learning for solving unit commitment problem with photo voltaic sources

142. Chandrasekaran K, Simon SP (2012) Binary/real coded particle swarm optimization for unit commitment problem, no 3

143. Senjyu T, Chakraborty S, Saber AY, Toyama H, Yona A (2008) Thermal unit commitment strategy with solar and wind energy systems using genetic algorithm operated particle swarm optimization, no PECon 08, pp 866-871

144. Chandrasekaran K, Simon SP, Prasad N (2014) Electrical power and energy systems SCUC problem for solar/thermal power system addressing smart grid issues using FF algorithm. Int J Electr Power Energy Syst 62:450-460

145. Anita JM, Raglend IJ (2013) Solution of emission constrained unit commitment problem using shuffled frog leaping algorithm. In: 2013 international conference on circuits, power and computing technologies (ICCPCT), pp 93-98

146. Kamboj VK, Bath SK, Dhillon JS (2016) Implementation of hybrid harmony/random search algorithm considering ensemble and pitch violation for unit commitment problem. Int J Electr Power Energy Syst 77:228-249

\section{Publisher's Note}

Springer Nature remains neutral with regard to jurisdictional claims in published maps and institutional affiliations.

\section{Submit your manuscript to a SpringerOpen ${ }^{\circ}$ journal and benefit from:}

- Convenient online submission

- Rigorous peer review

- Open access: articles freely available online

High visibility within the field

Retaining the copyright to your article

Submit your next manuscript at $>$ springeropen.com 